UNIVERSIDADE DE SÃO PAULO - USP

Faculdade de Filosofia, Ciências e Letras de Ribeirão Preto

Departamento de Química

Programa de Pós-Graduação em Química

\title{
Mutações sítio-dirigidas nas regiões do sítio-ativo e da interface oligomérica do Fator Inibitório da Migração dos Macrófagos de Leishmania major (LmMIF2)
}

Elise Marques Freire Cunha

Dissertação apresentada à Faculdade de Filosofia, Ciências e Letras de Ribeirão Preto da Universidade de São Paulo, como parte das exigências para a obtenção do título de Mestre em Ciências, Área: Química

Ribeirão Preto - SP 
UNIVERSIDADE DE SÃO PAULO - USP

Faculdade de Filosofia, Ciências e Letras de Ribeirão Preto

Departamento de Química

Programa de Pós-Graduação em Química

Mutações sítio-dirigidas nas regiões do sítio-ativo e da interface oligomérica do Fator Inibitório da Migração dos Macrófagos de Leishmania major (LmMIF2)

Elise Marques Freire Cunha

Dissertação de Mestrado

Orientador: Prof. Dr. Arthur Henrique Cavalcante de Oliveira

Ribeirão Preto - SP 


\section{FICHA CATALOGRÁFICA}

Cunha, Elise Marques Freire

Mutações sítio-dirigidas nas regiões do sítio-ativo e da interface oligomérica do Fator Inibitório da Migração dos Macrófagos de Leishmania major (LmMIF2)

96 p. : il. ; $30 \mathrm{~cm}$

Dissertação de Mestrado, apresentada à Faculdade de Filosofia, Ciências e Letras de Ribeirão Preto /USP - Área de concentração: Química.

Orientador: de Oliveira, Arthur Henrique Cavalcante.

1. Fator Inibitório da Migração de Macrófagos. 2. Mutagênese sítio-dirigida. 3. Leishmania major. 


\section{Dedicatória}

Dedico este krabaltho aos mens amados pais, Qdemar Carlos Cunha e Celeske OMarques Freire Cunha, pelo carinho, amor e apoio incondicional em todos os dias da minha vida. Obrigada por fazerem de mim uma pessoa methor.

Q̀s minhas irmás Raíssa e Samla e ao meu tio OTanoel pelo companheirismo e amizade.

$\grave{Q}$ minha avó, Dona Tenzinha, que mesmo sem entender direito pra que en estudo Kank, me apóia e reza para que en alcance os mens objetivos e volke logo para casa.

Qo men amigo e irmão que a vida me deu Malson OKeilson de Lucena, pela amizade, companheirismo, conselthos, apoio e paciência nos atrasos para o bandeijãa. 


\section{Qgradecimentos}

Qparentemente uma dissertação é fruto de um krabalho individual, porém, muitas pessoas são importantes para que o trabalho seja conchído.

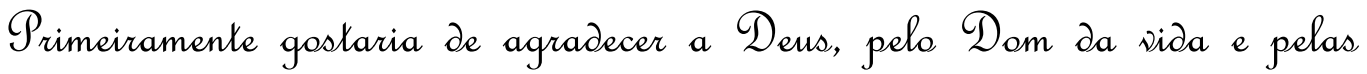
graças que me foram concedias.

Qo men orientador, Prof. Dr. Arthur Fenrique Cavalcante de Oliveira, pela confiança, oportunidade de crescimento profissional e pelos grandes ensinamentos ao longo do desenvolimento deste trabalho. Фं ele os acertos desta pesquisa ficando o ônus das possiveis falthas a esta pesquisadora.

Qos mens colegas do Saboratório de Bioquímica de Prokénas: Pakrícia, Plinio, Mariana, Ana Paula, Bruno, Thari (Love), pela acolhida, amizade, momentos de aprendizagem e desconkração.

Qo Prof. Dr. Richard Gohn Ward, pelo uso de seu laboratório awranke o desenvolivimento deste krabatho e pelos consethos. Wos seus ahnos: Carlinha, Guliana, Raquel, Otinive, Sucas, Gilvan, Stéfany e Leticia e aos ex-ahnos: Roberto e Jati.

Q Po Prof. Dr. Pietro Ciancaglini, pela disponibilidade de seus equipamentos, pela simpatia e pelos consethos e as suas ahnas: Guliana e OTarcelle.

Q Prof. Dr. Celso Jeixeira Mendes Gúnior pela convirência no laboratório, pelos conselhos e amizade.

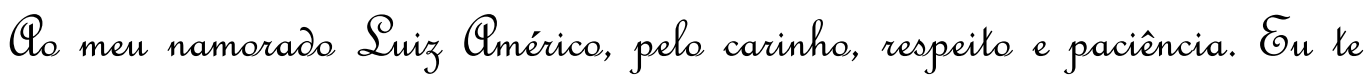
amo! 
Mos meus grandes amigos da Bioquímica, que foram muito importantes em todos as momentos difíceis e felizes em Ribeirão: Malson, Oivian, Bárbara,

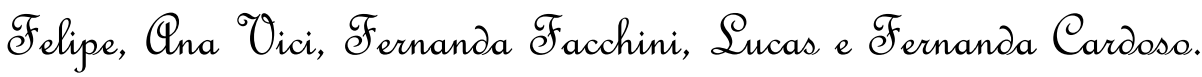

Qos meus amigos aa Química que são muito especiais para mim: Thariana, Ana Paula, Bruno, Leka, Goyce, $\oint_{u}$ Alponti e Leticia.

Tão podia deixar de agradecer também aos amigos: Rafael, Iracema, Diego, Ticole, Eliza, Thiago e Silvana.

Qos técnicos: Tânia, Qnaré, OTércia, Otiltinho e Vitor pelo trabalho

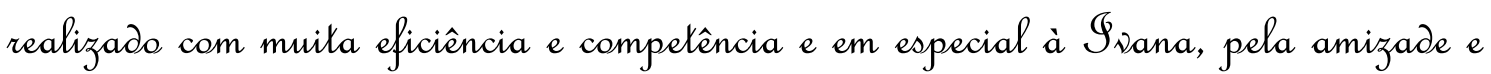
apoio sempre!

Qo pessoal da Secretaria do departamento de Química, da Secretaria de Pós-Sradnação, em especial a Lâmia pela enorme paciência e cooperação.

Qos colegas do Laboratório do Prof. Leone, Suliana e Daniela.

Qo Serwiço de Akendimento Social deske Campus pela competência, apoio e profissionalismo.

Qos colegas aa Casa 13 pelos momentos de desconkração.

Qos colegas do Instituto Federal de Rondônia: Lowrival, Gones, Qdalberto, Assis, Martison, Qna Paula, Gilmar e Vonivalao, pelo apoic e amizade.

¿े Frapesp pela concessão da bolsa de Thestrado e a colaboração com recursos financeiros para a realizacãa desta pesquisa. 
"Sulgue seu sucesso por aquilo que socê teve que renunciar para consegui-lo!" Dalai Lama 


\section{SUMÁRIO}

Pág.

\begin{tabular}{|l|r|}
\hline Lista de Figuras & 10
\end{tabular}

\begin{tabular}{|l|l|l|}
\hline Resumo & 13 \\
\hline
\end{tabular}

\begin{tabular}{|l|l|}
\hline Abstract & 14 \\
\hline
\end{tabular}

\begin{tabular}{|l|l|l|}
\hline Lista de Símbolos e Abreviaturas & 15
\end{tabular}

Nomenclatura, classificação e estrutura dos 20 aminoácidos encontrados \begin{tabular}{l|l} 
em sistemas biológicos & 17
\end{tabular}

1 Introdução 19

\begin{tabular}{|l|l|}
\hline 1.1 O protozoário Leishmania e a Leishmaniose & 20 \\
\hline
\end{tabular}

\begin{tabular}{|l|l|}
\hline 1.2 & $\mathrm{O}$ Fator Inibitório da Migração de Macrófagos \\
\hline
\end{tabular}

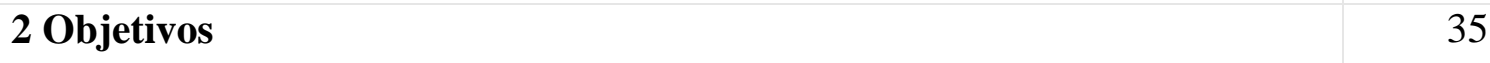

\begin{tabular}{|l|l|l|}
\hline 2.1 Objetivo Geral & 36 \\
\hline
\end{tabular}

\begin{tabular}{|l|l|}
\hline 2.2 Objetivos Específicos & 36 \\
\hline
\end{tabular}

3 Materiais e Métodos $\quad 37$

3.1 Mutagênese sítio-dirigida por Reação em cadeia da polimerase (PCR) 38

\begin{tabular}{|l|l|}
3.2 Preparação do Vetor pET21b & 41
\end{tabular}

\begin{tabular}{|l|l|l|}
\hline 3.3 Ligação do Fragmento Mutado ao Vetor pET21b & 42 \\
\hline
\end{tabular}

3.4 Preparação de células E. coli $\mathrm{DH} 5 \alpha$ competentes $\quad 42$

\begin{tabular}{|l|l|l}
3.5 Transformação em E. coli DH5 $\alpha$ & 43 \\
\hline
\end{tabular}

\begin{tabular}{|l|l|l|l|}
3.6 & PCR de Colônia & 44
\end{tabular}

3.7 Extração do DNA de MIF mutante de células DH5 $\alpha$ de E. coli 45

\begin{tabular}{|l|l|l|}
\hline 3.8 Sequenciamento de nucleotídeos de DNA & 46
\end{tabular}

3.9 Expressão e Purificação de pET21bLmMIF2 e pET21bMIF Mutante de E. \begin{tabular}{|l|l|}
\hline coli linhagem BL21[DE3]pLysS & 47
\end{tabular}

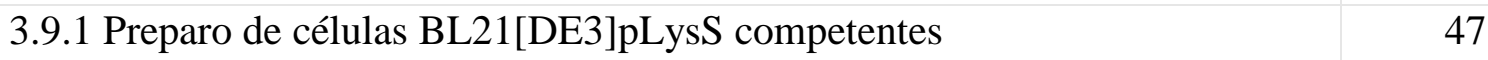

3.9.2 Transformação rápida de E. coli linhagem BL21[DE3]pLysS 48

3.9.3 Teste de Expressão da $L m M I F 2$ nativa e MIF mutante $\quad 48$

\begin{tabular}{|l|l|l|} 
3.9.4 Preparação dos Extratos de Bactéria & 49
\end{tabular}

\begin{tabular}{|l|r|}
\hline 3.9.5 Teste de Solubilidade das Proteínas Expressas & 50
\end{tabular} 
\begin{tabular}{|l|r|} 
3.9.6 Eletroforese em Gel Desnaturante de Poliacrilamida & 50
\end{tabular}

\begin{tabular}{|l|l|l|} 
3.9.7 Expressão da MIF nativa e MIF mutante para purificação & 51
\end{tabular}

3.9.8 Purificação do $r L m M I F 2$ nativa e MIF mutante por cromatografia de afinidade

3.10 Quantificação de Proteínas

3.11 Análise da estrutura de MIF recombinante e os mutantes em solução 52

3.11.1 Determinação da Massa Molecular 52

\begin{tabular}{|l|l|l|} 
3.11.2 Dicroísmo Circular & 54
\end{tabular}

3.11.3 Espectrofluorescência da Emissão Intrínseca do Triptofano 55

\begin{tabular}{|l|l|}
\hline 3.12 Ensaio da Migração de Macrófagos & 56
\end{tabular}

4 Resultados e Discussão $\quad 57$

\begin{tabular}{|l|l|l|l} 
4.1 Mutagênese sítio-dirigida por PCR & 59
\end{tabular}

\begin{tabular}{ll|} 
4.2 Digestão dos fragmentos com enzimas NdeI e HindIII & 60
\end{tabular}

\begin{tabular}{|l|l|}
4.3 Clonagem dos fragmentos mutantes no vetor de expressão pET21b & 61
\end{tabular}

\begin{tabular}{|l|l|}
\hline 4.4 Sequenciamento dos mutantes de MIF & 62
\end{tabular}

4.5 Expressão em linhagem BL21[DE3]pLysS de E. coli e purificação das \begin{tabular}{|l|l|}
\hline proteínas recombinante e mutantes & 64 \\
\hline
\end{tabular}

4.6 Determinação da Massa Molecular por Cromatografia de Filtração em Gel 66

\begin{tabular}{|l|l|}
\hline 4.7 Avaliação Estrutural por Dicroísmo Circular & 68
\end{tabular}

4.8 Análise espectroscópica do efeito do $\mathrm{pH}$ na estrutura do $r L m M I F 2$ e dos mutantes

\begin{tabular}{|l|l|}
\hline 4.8.1 Dicroísmo Circular & 71
\end{tabular}

\begin{tabular}{|l|l|} 
4.8.2 Emissão de Fluorescência Intrínseca de Triptofanos (IFTE) & 75
\end{tabular}

\begin{tabular}{|l|l|}
\hline 4.9 Efeito das mutações na atividade funcional da $r L m M I F 2$ & 81
\end{tabular}

5 Considerações Finais $\quad 86$

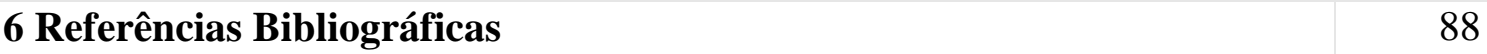




\section{LISTA DE FIGURAS}

Pág.

Figura 01: Leishmania sp. A) Formas promastigotas de Leishmania sp encontradas no intestino do vetor marcadas com anticorpos e DAPI, observadas em microscopia de fluorescência. B) Dois macrófagos, distinguidos dos pelos núcleos, contendo formas amastigotas (indicado pelas setas) no seu citoplasma

Figura 02: Ciclo de Vida da Leishmania

Figura 03: Estrutura conservada entre LmMIF1, mMIF (mamífero) e LmMIF 2. Representação esquemática da forma monomérica, com elementos da estrutura secundária folhas $\beta$ mostrados em azul em $\mathrm{A}$ e $\mathrm{B}$ e rosa em $\mathrm{C}$, e, $\alpha$-hélices, em vermelho, para $\mathrm{A}$ e $\mathrm{B}$ e em roxo para $\mathrm{C}$

Figura 04: Estrutura conservada entre $L m$ MIF1, LmMIF2 e mMIF, representação esquemática da forma trimérica

Figura 05: Esquema ilustrativo de mutagênese sítio-dirigida por reação em cadeia de polimerase. EXT1, EXT2, T7 Promoter e MUT: oligonucleotídeos complementares a sequiência molde; Nde I e Hind III representam as posições dos sítios de restrição enzimáticos

Figura 06: Resultado da etapa da reação de mutagênese sítio-dirigida. Gel de agarose $1 \%$ referente a reação 1 de mutagênese sítio-dirigida. $M$ - Marcador de peso molecular 1 Kb Plus (Invitrogen). De 1 a 5 têmse respectivamente os mutantes W108F, K34E, W66L, P2G e o mutante $\Delta(104-113)$

Figura 07: Gel de agarose 1\% referente as reações 2 e 3 da mutagênese sítio-dirigida. M-Marcador de peso molecular $1 \mathrm{~Kb}$ Plus (Invitrogen); (1) Fragmento referente ao mutante K34E; (2)W66L, (3) $\mathrm{W} 108 \mathrm{~F}$ e (4) $\mathrm{P} 2 \mathrm{G}$ com fragmentos de aproximadamente $634 \mathrm{pb}$.

Figura 08: Digestão dos fragmentos da reação 3. Gel de agarose $1 \%$ referente à digestão com enzimas de restrição NdeI e HindIII liberando o fragmento de $\sim 350 \mathrm{pb}$. Em $\mathrm{M}$ temos o marcador de peso molecular de $100 \mathrm{pb}$ (Invitrogen); (1) Mutante W108F; (2) K34E; (3) W66L; (4) P2G

Figura 09: Gel de Agarose 1\% do PCR de Colônia Gel de Agarose 0,8\% M

- Marcador de peso molecular $1 \mathrm{~Kb}$ Plus e 1 a 5 amplificações do clone W108F de $\sim 650 \mathrm{pb}$ mostrando que houve correta ligação do inserto no vetor 
Figura 10: Gel de Agarose 1\% da extração de plasmídeo de bactérias transformadas com pET21MIFMUT. Na canaleta 1) Marcador 1 Kb Plus; 2)pET21b vazio; 3)pET21brLmMIF2; 4)pET21bMUT W108F; 5)pET21bMUT - K34E; 6)pET21bMUT - W66L; 7)pET21bMUT - P2G; 8)pET21bMUT - $\Delta(104-113)$

Figura 11: Eletroferogramas das mutações. Em (1A) tem-se o códon CCG que codifica o aminoácido Pro, e em (1B) observa-se a mutação para o códon GGC que codifica o aminoácido Gly. Em (2A) e (2B) K34E; (3A) e (3B) W66L e (4A) e(4B) W108F

Figura 12: Eletroferograma da mutação $\Delta$ (104-113). (A) MIF de Leishmania major selvagem e (B) deleção dos aminoácidos $\Delta$ (104-113)

Figura 13: Gel SDS-PAGE de expressão e solubilidade das proteínas mutantes. M=Marcador de Peso Molecular - LWM (GE lifesciences); $\mathrm{C}=$ Controle de Expressão com pET21b sem a inserção do gene; $\mathrm{T}=0$ (tempo de indução de 0horas) $\mathrm{T}=6$ (tempo de indução de 6horas); $\mathrm{S}=$ Extrato Solúvel e I= Extrato Insolúvel ...

Figura 14: Gel de Purificação SDS-PAGE 15\% com gradiente de eluição do mutante W108F. (LW) Marcador de Peso Molecular. (E8) Eluição com 150mM de Imidazol (E9 - E10) 200mM de Imidazol (E15 - E16) 250mM de Imidazol

Figura 15: Perfil cromatográfico da $r L m M I F 2$, das proteínas mutantes e proteínas padrões obtidos por cromatografia de filtração em gel. A coluna foi equilibrada com $20 \mathrm{mmol} . \mathrm{L}^{-1}$ TRIS, 50mmol. $\mathrm{L}^{-1}$ $\mathrm{NaCl}, \mathrm{pH} 7,5$ e fluxo de $0,5 \mathrm{~mL} \cdot \mathrm{min}^{-1}$. O volume de injeção de $1 \mathrm{~mL}$ de cada padrão e da proteína $\left(1 \mathrm{mg} \cdot \mathrm{mL}^{-1}\right)$ foram aplicados isoladamente

Figura 16: Perfil de correlação - Coeficiente de partição $K_{\mathrm{Av}}$ versus o logaritmo da massa molecular dos padrões aplicados na coluna Sephacryl $^{\text {TM }}$ S-100. A equação da reta relaciona o logaritmo da massa molecular em kDa (MW) com o coeficiente de partição $\left(\mathrm{K}_{\mathrm{AV}}\right)$. O coeficiente de partição é calculado por meio da equação $\mathrm{K}_{\mathrm{AV}}=\mathrm{V}_{\mathrm{e}}-\mathrm{V}_{\mathrm{o}} / \mathrm{V}_{\mathrm{T}}-\mathrm{V}_{\mathrm{o}}$ onde $\mathrm{V}_{\mathrm{e}}=$ Volume de eluição, $\mathrm{V}_{\mathrm{o}}=$ Volume de eluição do Blue Dextran e $\mathrm{V}_{\mathrm{T}}=$ Volume total da coluna.

Figura 17: Espectro de Dicroísmo Circular no UV distante em pH 7.0 O gráfico ilustra os espectros de $\mathrm{CD}$ de MIF recombinante juntamente com os mutantes após expressão e purificação

Figura 18: Análise por Dicroísmo Circular UV-próximo da rLmMIF2 e os mutantes P2G, W66L e W108F em pH 7. As medidas foram realizadas a $25^{\circ} \mathrm{C}$ com $0,5 \mathrm{mg}$ de proteína em $1 \mathrm{~mL}$ de tampão $20 \mathrm{mM}$ fosfato/citrato 
Figura 19: Análise por Dicroísmo Circular UV distante da proteína rLmMIF2 em função do $\mathbf{p H}$. As medidas foram realizadas a $25^{\circ} \mathrm{C}$ com $100 \mu \mathrm{g}$ de proteína em $200 \mu \mathrm{L}$ de tampão $20 \mathrm{mM}$ fosfato/citrato em pHs 7,0; 6,0; 5,0; 4,0 e 3,0. E tampão Glicina/HCl em pH2,0 ....

Figura 20: Análise por Dicroísmo Circular UV-próximo da proteína $r L m M I F 2$ em função do pH. As medidas foram realizadas a $25^{\circ} \mathrm{C}$ com $0,5 \mathrm{mg}$ de proteína em $1 \mathrm{~mL}$ de tampão $20 \mathrm{mM}$ fosfato/citrato em pHs 7,0; 5,0 e 3,0

Figura 21: Análise por Dicroísmo Circular UV-distante dos mutantes de MIF em função do $\mathbf{p H}$. As medidas foram realizadas a $25^{\circ} \mathrm{C} \mathrm{com}$ $100 \mu \mathrm{g}$ de proteína em $200 \mu \mathrm{L}$ de tampão $20 \mathrm{mM}$ fosfato/citrato em pHs 7,0; 6,0; 5,0; 4,0 e 3,0. E tampão Glicina/ $\mathrm{HCl}$ em pH2,0 ....

Figura 22: Análise por Dicroísmo Circular UV-próximo em função do pH.

A) Mutante P2G; B) Mutante W66L; e C) W108F

Figura 23: Análise por espectroscopia de fluorescência da proteína rLmMIF2 em função do $\mathbf{p H}$. As medidas foram realizadas a $25^{\circ} \mathrm{C}$ com $0,060 \mu \mathrm{g} / \mathrm{mL}$ de proteína em tampão $20 \mathrm{mM}$ fosfato/citrato em pHs 7,0; 6,0; 5,0; 4,0 e 3,0 e tampão Glicina/ $\mathrm{HCl}$ pH 2,0

Figura 24: Análise por espectroscopia de fluorescência dos mutantes P2G, K34E, W66L e W108F em função do pH. As medidas foram realizadas a $25^{\circ} \mathrm{C}$ com $0,060 \mu \mathrm{g} / \mathrm{mL}$ de proteína em tampão $20 \mathrm{mM}$ fosfato/citrato em pHs 7,0; 6,0; 5,0; 4,0 e 3,0 e tampão Glicina/HCl $\mathrm{pH} 2,0$

Figura 25: Ensaio de migração de macrófagos na presença da proteína recombinante $\operatorname{LmMIF2}$ e mutantes. Para análise de migração foram utilizadas $7 \times 10^{4}$ macrófagos cultivados na presença de LPS 100ng, MIF e mutantes 100ng. A migração de macrófagos foi determinada a partir do número de células que passaram da faixa central criada na lâmina

Figura 26: Ensaio de migração de macrófagos com $L m M I F 2$ e mutantes na presença de Polimixina $B$. Para análise de migração foram utilizadas $7 \times 10^{4}$ macrófagos cultivados na presença de Polimixina B $30 \mu \mathrm{g} / \mathrm{mL}$

Figura 27: Ensaio de migração de macrófagos pré-incubados com LmMIF2 e mutantes e incubados com 100ng/mL de LPS 


\section{RESUMO}

O fator inibitório da migração de macrófagos (MIF) é considerado um importante fator no controle de infecções causadas por patógenos. Essa proteína foi encontrada primeiramente em mamíferos, mas verificou-se a presença de ortólogas em patógenos, sendo sugerida uma função moduladora do sistema imunológico do hospedeiro. A caracterização estrutural e funcional da proteína MIF em Leishmania major pode contribuir para o entendimento das funções dessa proteína na relação parasita/hopedeiro. Este trabalho teve como objetivo realizar mutações sítio-dirigidas da sequência codificadora do fator inibitório da migração de macrófagos de Leishmania major (LmMIF2) e investigar o efeito dessas mutações na manutenção da estrutura e na função dessa proteína. A mutagênese sítio-dirigida foi realizada em 3 etapas de reações de PCR, os fragmentos obtidos foram purificados, seqüenciados e clonados em vetor pET21b usando as enzimas de restrição NdeI e HindIII. A LmMIF2 recombinante (rLmMIF2) e os mutantes P2G, K34E, W66L, W108F e $\Delta 104-113$, todos eles contendo uma cauda de histidina, foram eficientemente expressos na forma solúvel em $E$. coli e foram purificados do lisado celular por cromatografia de afinidade. O gel de SDSPAGE mostrou uma banda única em $14.5 \mathrm{kDa}$ e análises de filtração em gel mostraram que, em solução, o rLmMIF2 e os mutantes apresentaram-se como dímeros. Experimentos de dicroísmo circular (CD) e de emissão de fluorescência intrínseca de triptofanos (IFTE) foram realizados para acompanhar as mudanças na estrutura secundária e terciária dessas proteínas na variação de $\mathrm{pH}$ do ambiente. Análises de $\mathrm{CD}$ UV-distante e UV-próximo mostraram que a mutação de apenas um aminoácido pode influenciar na estrutura secundária e terciária da rLmMIF2 e que as mutações não alteraram a formação de estado de glóbulo fundido em baixos pHs. Os experimentos de IFTE mostraram que há um efeito de supressão intrínseca de fluorescência que foi abolido com a substituição do triptofano da posição 108. O mutante W66L mostrou uma intensidade de fluorescência $60 \%$ menor enquanto o mutante W108F apresentou uma intensidade $25 \%$ maior do que a rLmMIF2. Ensaios de inibição da migração de macrófagos mostraram que o mutante $\mathrm{P} 2 \mathrm{G}$ apresentou atividade de inibição da migração similar à rLmMIF2, enquanto os outros mutantes apresentaram uma atividade diminuída em cerca de 50\%. Estes resultados contribuem para elucidar o papel de regiões da LmMIF2 envolvidas na manutenção da estrutura e em mudanças conformacionais da proteína, que podem estar envolvidas na atividade de modulação da resposta imune do hospedeiro. 


\begin{abstract}
The macrophage migration inhibitory factor (MIF) is considered an important factor in the control of infections caused by pathogens. This protein was first identified in mammals but orthologues have also been found in pathogens and it has been suggested that the protein a modulates the function of the host immune system. The structural and functional characterization from the MIF of Leishmania major may therefore contribute to the understanding of the function of this protein in the host/parasite relationship. This study aimed to use site-directed mutagenesis in the macrophage migration inhibitory factor of L. major (LmMIF2) to investigate the protein structure and function. Site-directed mutagenesis was performed by PCR and the mutants were cloned into the $\mathrm{pET} 21 \mathrm{~b}$ vector using NdeI/HindIII restriction sites. The recombinant $L m$ MIF2 (rLmMIF2) and P2G, K34E, W66L, W108F and $\Delta 104-113$ mutants, all containing a His6-tag, were efficiently expressed in soluble form in E. coli and, subsequently purified from cell lysate by affinity chromatography. A single protein band of $14.5 \mathrm{kDa}$ was observed in SDS-PAGE, and gel filtration analysis showed rLmMIF and mutants to be dimeric proteins. Circular dichroism (CD) and intrinsic fluorescence emission of tryptophan (IFTE) were performed to monitor $\mathrm{pH}$-dependent changes in secondary and tertiary structure of these proteins. Far-UV and near-UV-CD analysis showed that the exchange of one amino acid can influence the secondary and tertiary structures of $\mathrm{r} L m \mathrm{MIF} 2$ and that the mutations did not change the molten globule state formation at low $\mathrm{pH}$. IFTE experiments showed that there is an intrinsic fluorescence quenching that is abolished by the W108 substitution. Compared with the r $L m$ MIF2, the W66L mutant showed a decrease in fluorescence intensity of about $60 \%$, whereas the W108F mutant presented a fluorescence increase of about $25 \%$. Macrophage migration inhibition tests showed that the P2G mutant presented a similar inhibitory activity to the $\mathrm{r} L m \mathrm{MIF} 2$, while the other mutants showed a decrease in activity of about $50 \%$. These results contribute to elucidate the role of the regions involved in maintaining LmMIF2 structure and its conformational changes, which may be involved in the host immune response modulation.
\end{abstract}




\section{LISTA DE SÍMBOLOS E ABREVIATURAS}

\begin{tabular}{|c|c|}
\hline ATP & Adenosina Trifosfato \\
\hline BSA & Soroalbumina bovina \\
\hline $\mathrm{CD}$ & Dicroísmo Circular \\
\hline $\mathrm{C} \alpha$ & Átomo de carbono na posição $\alpha$ da carbonila \\
\hline DAPI & 4,6-diamidino-2-phenylindole \\
\hline DNA & Ácido desoxirribonucléico \\
\hline dNTP & Desóxido Nucleotídeo Difosfato \\
\hline DTT & Ditiotreitol \\
\hline gp63 & Leishmanolisina \\
\hline G & Grama \\
\hline IFTE & Emissão Fluorescência Intrínseca do Triptofano \\
\hline IL & Interleucina \\
\hline IPTG & isopropil-ß3-D-tiogalactopiranosídeo \\
\hline $\mathrm{K}_{\mathrm{Av}}$ & Coeficiente de partição \\
\hline $\mathrm{Kb}$ & Kilobase \\
\hline $\mathrm{kDa}$ & Kilobase \\
\hline$L m$ & Leishmania major \\
\hline$L m M I F 1$ & Gene de MIF localizado na posição 1740 no cromosso 33 de L. major \\
\hline$L m M I F 2$ & Gene de MIF localizado na posição 1750 no cromosso 33 de L. major \\
\hline $\mathrm{L}$ & Litro \\
\hline LPG & Lipofosfoglicano \\
\hline LPS & Lipopolissacarídeo de E. coli \\
\hline LTA & Leishmaniose Tegumentar Americana \\
\hline LVA & Leishmaniose Visceral Americana \\
\hline MIF & Fator Inibitório da Migração dos Macrófagos \\
\hline $\mathrm{MIF}^{+/+}$ & Presença do Gene MIF \\
\hline $\mathrm{MIF}^{-/-}$ & Ausência do Gene MIF \\
\hline MG & Miligrama \\
\hline $\mathrm{mL}$ & Mililitro \\
\hline $\mathrm{mM}$ & Milimolar \\
\hline Ni-NTA & Ácido nitrilotriacético de níquel \\
\hline$\eta g$ & Nanôgrama \\
\hline$\eta \mathrm{m}$ & Nanômetro \\
\hline $\mathrm{NO}$ & Óxido Nítrico \\
\hline $\mathrm{OD}_{600}$ & Densidade Óptica em 600 nm \\
\hline PB & Pares de Bases \\
\hline PBS & Tampão Fosfato-Salina \\
\hline PCR & Reação em Cadeia Polimerase \\
\hline
\end{tabular}




\begin{tabular}{|c|c|}
\hline $\mathrm{pET}$ & Plasmídeo para expressão pela T7 RNA polimerase \\
\hline $\mathrm{pH}$ & Potencial Hidrogeniônico \\
\hline Pmol & Picomol \\
\hline$r L m M I F 2$ & MIF de L. major 2 (1750) recombinante \\
\hline RPM & Rotações por minuto \\
\hline SDS & Dodecilsulfato de Sódio \\
\hline SDS-PAGE & Eletroforese em gel desnaturante de poliacrilamida \\
\hline TNF- $\alpha$ & Fator de Necrose Tumoral alfa \\
\hline TRIS & Tris[hidroximetil]aminometano \\
\hline $\mathrm{U}$ & Unidade de Enzima \\
\hline UV & Ultravioleta \\
\hline UV distante & Ultravioleta na região de comprimento de onda entre $190-250 \mathrm{~nm}$ \\
\hline UV próximo & Ultravioleta na região de comprimento de onda entre $250-330 \mathrm{~nm}$ \\
\hline $\mathrm{V}_{\mathrm{e}}$ & Volume de Eluição \\
\hline $\mathrm{V}_{\mathrm{o}}$ & Volume de Eluição do Blue Dextran \\
\hline $\mathrm{V}_{\mathrm{t}}$ & Volume total da coluna. \\
\hline$\AA$ & Ångström \\
\hline$\sim$ & Aproximadamente \\
\hline \máx & Comprimento de Onda Máximo \\
\hline$\mu \mathrm{g}$ & Micrograma \\
\hline$\mu \mathrm{L}$ & Microlitro \\
\hline$\mu \mathrm{m}$ & Micrômetro \\
\hline
\end{tabular}


Nomenclatura, classificação e estrutura dos 20 aminoácidos encontrados em sistemas biológicos.

Não polares

$+\mathrm{H}_{3} \mathrm{~N}-\mathrm{C}_{\mathrm{H}}^{\mathrm{COO}}-\mathrm{H}$<smiles>CC([NH3+])C(=O)[O-]</smiles>

Glicina

(Gly)

(G)
Alanina

(Ala)

(A)<smiles>CC(C)C([NH3+])C(=O)[O-]</smiles>

Valina

(Val)

(V)

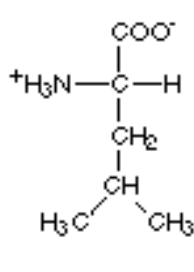

Leucina (Leu)

(L)<smiles>CSCCC([NH3+])C(=O)[O-]</smiles>

Metionina

(Met)

(M)<smiles>CCC(C)C([NH3+])C(=O)[O-]</smiles>

Isoleucina

(Ilo)

(I)

\section{Aromáticos}<smiles>[NH3+]C(Cc1ccccc1)C(=O)[O-]</smiles>

Fenilalanina

(Phe)

(F)<smiles>NC(Cc1ccc(O)cc1)C(=O)[O-]</smiles>

Tirosina

(Tyr)

(Y)<smiles>NC(Cc1c[nH]c2ccccc12)C(=O)[O-]</smiles>

Triptofano

(Trp)

(W)

\section{Polares não carregados}<smiles>N[C@H](CO)C(=O)[O-]</smiles><smiles>CC(O)C([NH3+])C(=O)[O-]</smiles><smiles>NC(CS)C(=O)[O-]</smiles>

Cisteína

Serina (Ser)

(S)
Treonina

(Thr)

(T)
(Cys)

(C)<smiles>NC(=O)CCC([NH3+])C(=O)[O-]</smiles>

Glutamina (Gln)

(Q)<smiles>O=C([O-])C1CCCN1</smiles><smiles>NC(=O)CC(N)C(=O)[O-]</smiles>

(Pro)

(Pro)

(P)
Asparagina (Asn) 


\section{Positivamente carregados}<smiles>NC(Cc1c[nH]c[nH+]1)C(=O)[O-]</smiles>

Histidina

(His)

(H)

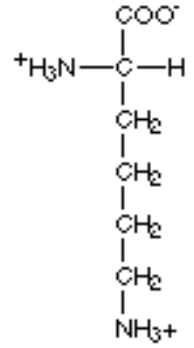

Lisina

(Lys)

(K)

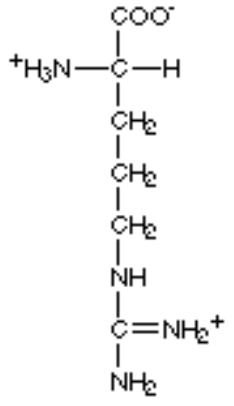

Arginina

(Arg)

(R)

Negativamente carregados<smiles>NC(CC(=O)[O-])C(=O)[O-]</smiles>

Aspartato

(Asp)

(D)<smiles>NC(CCC(=O)[O-])C(=O)[O-]</smiles>

Glutamato (Glu) 


\section{Introdução}




\section{Introdução}

\subsection{O protozoário Leishmania e a Leishmaniose}

A leishmaniose é uma doença infecto-parasitária não contagiosa causada por protozoários do gênero Leishmania, que ocorrem de forma predominante em regiões tropicais e subtropicais (Alves et al., 2003). Doenças causadas por parasitos protozoários são responsáveis por inúmeros casos de morbidade e mortalidade em vários países, caracterizando um sério problema de saúde pública (Ouellette et al., 2004; Tiuman et al., 2005). A leishmaniose acomete 12 milhões de pessoas no mundo inteiro, com incidência anual de dois milhões de novos casos e, devido à falta de investimentos da indústria farmacêutica no desenvolvimento de fármacos para o tratamento dos infectados, esta parasitose é classificada como negligenciada (Ashfold, Desjeux \& Deraadt, 1992; Kayser et al., 2000; Abu-Raddad et al., 2006; Who, 2010).

Os membros da família Trypanosomatidae (Ordem Kinetoplastida, Protozoa) são organismos unicelulares que parasitam hospedeiros vertebrados e invertebrados. Cerca de 30 espécies do gênero Leishmania infectam mamíferos, causando as leishmanioses. A classificação desses protozoários baseia-se no aspecto clínico e epidemiológico das doenças que produzem no homem, nas características do parasito em animais de laboratório e nos insetos vetores. Dois gêneros de insetos transmitem esses protozoários ao homem: Phlebotomus, no velho mundo, e Lutzomyia, na América. Populações humanas de 80 países são afetadas pela leishmaniose sendo a grande maioria dos países atingidos pela parasitose, classificados como subdesenvolvidos ou em desenvolvimento (Ashfold, Desjeux \& Deraadt, 1992; Who, 2010). 
Avanços representados pela microscopia eletrônica, biologia molecular, bioquímica e imunologia abriram novas perspectivas na taxonomia de Leishmania. O sistema de classificação é suplementado com uma variedade de técnicas moleculares, como hibridização de DNA, eletroforese de produtos de DNA do cinetoplasto, mobilidade eletroforética de isoenzimas e anticorpos monoclonais, que definem características intrínsecas de cada parasita (Marfurt et al., 2003; Wortmann et al., 2001).

Shaw (1994) lista 30 espécies do subgênero Leishmania, das quais 10 ocorrem no Velho Mundo e 20 no Novo Mundo. Todas as espécies do Velho Mundo pertencem ao subgênero Leishmania, enquanto que na América as espécies também pertencem ao subgênero Viannia (Lainson e Shaw, 1987; Pimenta et al., 1991). O gênero Leishmania agrupa um considerável número de espécies de protozoários unicelulares e flagelados que são caracterizados principalmente pela presença de uma única mitocôndria e uma rede de microtúbulos subpeliculares bastante rígida, conferindo a estes protozoários formas celulares bem definidas durante seu ciclo evolutivo (Shaw, 1994).

As manifestações clínicas da leishmaniose são variáveis e dependem da associação entre as características de virulência da espécie de Leishmania infectante e da resposta imunológica do hospedeiro (Pearson \& Sousa, 1996). De acordo com as manifestações clínicas, a leishmaniose pode ser classificada de duas formas distintas: Leishmaniose Tegumentar Americana (LTA) e Leishmaniose Visceral Americana (LVA). A LTA, por sua vez, é classificada como leishmaniose cutânea, caracterizada por úlceras crônicas na pele, desenvolvidas no local da picada do inseto vetor, e que podem levar meses para cicatrizar (Balaña-Fouce et al., 1998); e leishmaniose mucocutânea, que no início causa úlceras na pele similares àquelas da leishmaniose cutânea, que cicatrizam para depois reaparecerem, principalmente nas mucosas do nariz, boca e faringe. A leishmaniose mucocutânea é, geralmente, acompanhada por infecções 
secundárias e destruição de grandes extensões do tecido em pacientes tratados contra leishmaniose visceral ou paciente com baixa imunidade. A Leishmaniose Visceral Americana (LVA), ou Calazar, é uma doença sistêmica muito grave, caracterizada pela migração dos parasitas para o fígado, baço e a medula óssea, podendo levar o hospedeiro a morte. Tanto a LVA quanto a LTA possuem um caráter evolutivo crônico (Handman, 2001; Basano e Camargo, 2004; Who, 2010).

O ciclo de vida do parasito é composto por duas formas morfológicas principais: as promastigotas e as amastigotas (Figura 1) (Albuquerque, 2006). Na primeira forma o parasita é flagelado e móvel (promastigota procíclico). Em Leishmania major, o parasita adere-se às células epiteliais no trato digestivo do inseto hospedeiro através da interação de um glicoconjugado de superfície, o lipofosfoglicano (LPG), com os receptores dessas células (Pimenta et al., 1992). Nesse estágio ocorre a multiplicação do protozoário e a diferenciação da forma promastigota procíclica (não infectiva) para a forma promastigota metacíclica (infectiva), também conhecida como metaciclogênese, estágio em que ocorre uma duplicação nas repetições dos oligossacarídeos do LPG, uma diminuição dos resíduos terminais de galactose e um aumento de resíduos terminais de arabinose, resultando no desligamento do inseto aderido às células epiteliais e na migração para a extremidade anterior do trato digestivo, seguindo para o aparelho sugador (Sacks, Brodin \& Turco, 1990; Pimenta et al., 1992). A transmissão dos protozoários dos vetores para os hospedeiros vertebrados ocorre a partir da picada da fêmea do flebotomíneo infectada, que busca alimento - repasto sanguíneo para a maturação dos ovos (Pimenta et al., 1992). 

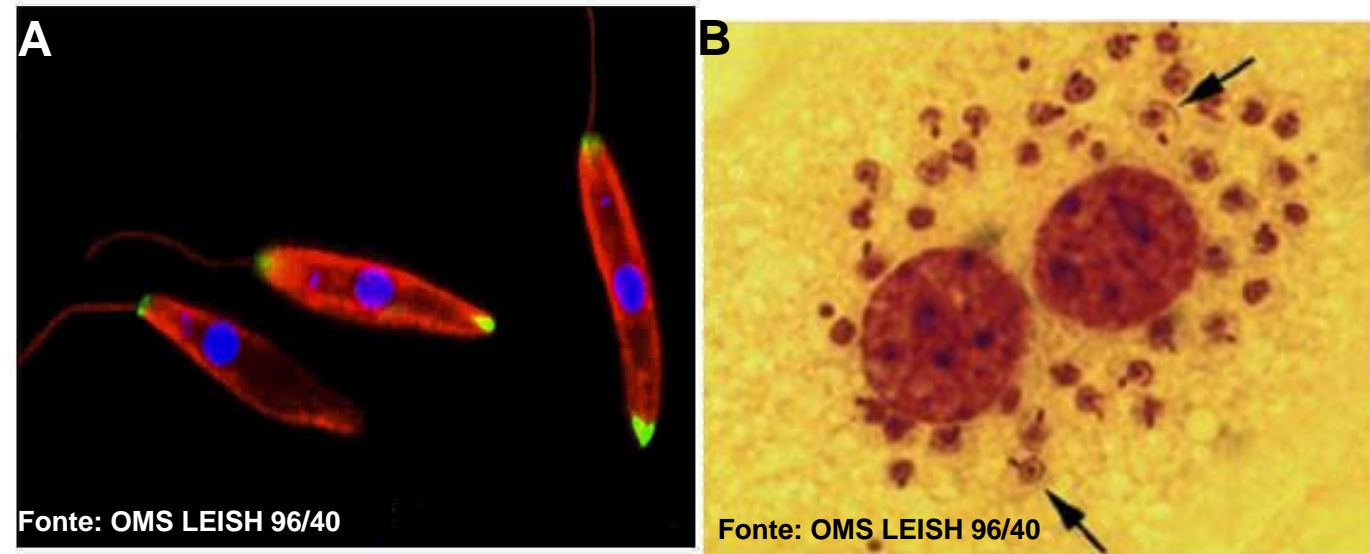

Figura 01: Leishmania sp A) Formas promastigotas de Leishmania sp encontradas no intestino do vetor marcadas com anticorpos e DAPI, observadas em microscopia de fluorescência. B) Dois macrófagos, distinguidos dos pelos núcleos, contendo formas amastigotas (indicado pelas setas) no seu citoplasma.

Ao picar o hospedeiro vertebrado, o vetor inocula as formas promastigotas metacíclicas infectantes do parasito, juntamente com a saliva - esta última com comprovado papel modulador de resposta imunológica do hospedeiro o que facilita o sucesso da infecção e a sobrevivência do parasito no hospedeiro vertebrado (Theodos e Titus, 1993). Os parasitos assumem a forma amastigota, com flagelo recolhido dentro da bolsa flagelar, no interior das células do sistema mononuclear fagocitário, principalmente macrófagos nos hospedeiros mamíferos. A forma amastigota do protozoário adere-se através do LPG e da metaloprotease gp63 interagindo com os receptores CR3 do macrófago (Chang \& Chaudhuri, 1990). A diferenciação e proliferação da forma amastigota nas condições hostis da célula é possível devido à fusão do fagossomo e do lisossomo, seguida da lise e liberação das formas diferenciadas que infectam outros macrófagos (Peters et al., 1995). Durante o repasto sanguíneo do inseto vetor em um vertebrado infectado, ocorre ingestão das formas amastigotas e em seu intestino ocorre a diferenciação em formas promastigotas, fechando o ciclo de vida do parasito (Hepburn, 2000; Handman, 2001) (Figura 2).

Como vários parasitos, Leishmania tem desenvolvido várias estratégias especializadas para escapar da resposta imune de seus hospedeiros, incluindo variação 
antigênica e sinalização subversiva para completar seu ciclo de vida (Palmer, 2007).

Uma série de estratégias são empregadas pelas formas amastigotas para sobreviver dentro dos vacúolos parasitóforos nos macrófagos, incluindo a inibição da produção de NO, de enzimas hidrolíticas e da quelação de cálcio (Turco \& Descoteaux, 1992). Vários fatores específicos parasito-hospedeiro desempenham um papel importante na persistência de Leishmania dentro das células infectadas e influenciam nas manifestações clínicas da doença, que incluem úlceras cutâneas e desenvolvimento visceral (Scharton-Kersten e Scott, 1995).

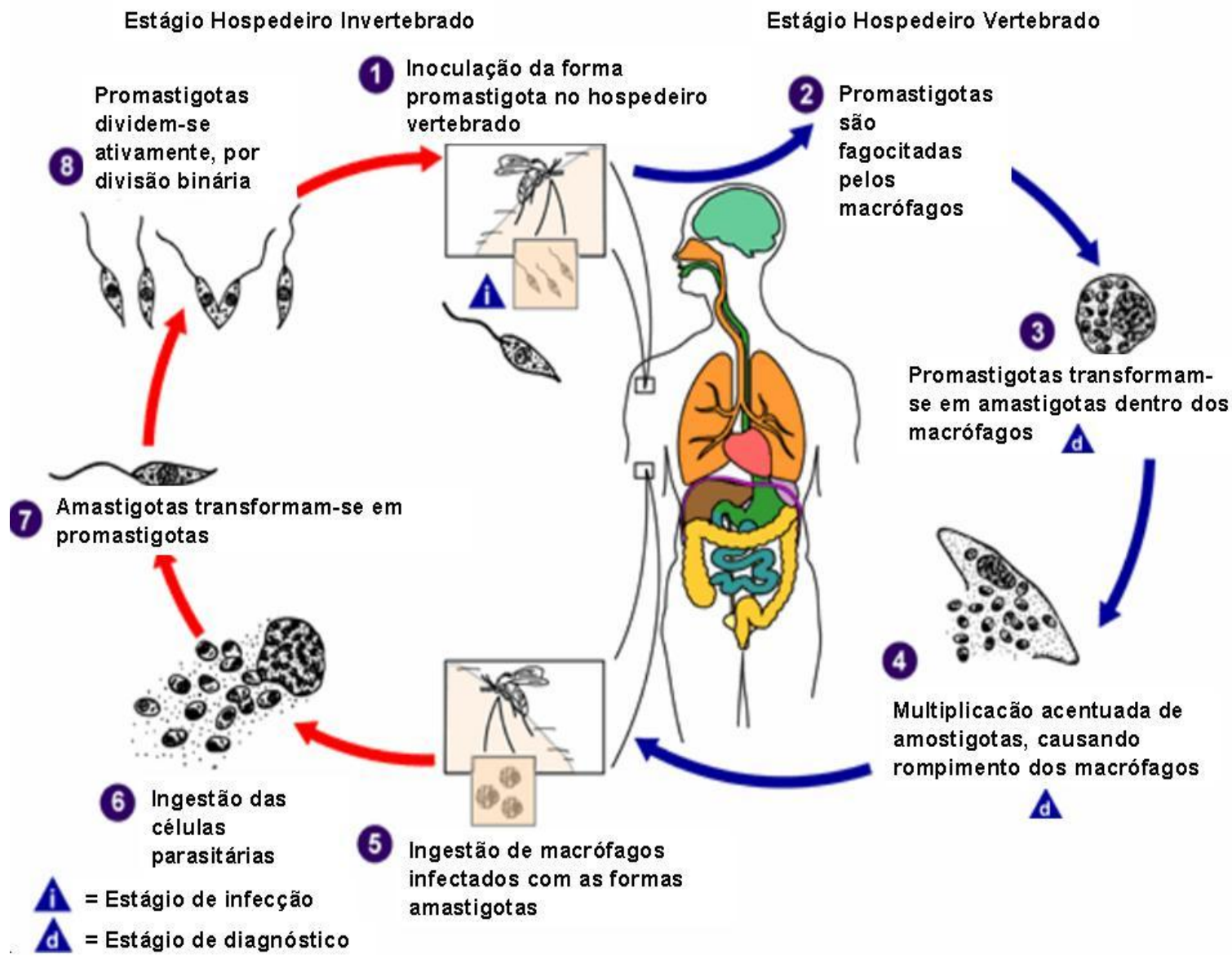

(Adaptado: http://www.uni-tuebingen.de/modeling/Mod_Leish_Cycle_en.html Acessado em: 13/07/2010)

Figura 02: Ciclo de Vida da Leishmania. 


\subsection{O Fator Inibitório da Migração de Macrófagos}

O Fator Inibitório da Migração de Macrófagos (MIF) foi descrito em 1966 como uma citocina produzida por linfócitos $\mathrm{T}$, sendo associado com a migração de macrófagos durante a resposta hipersensível retardada e com o efeito inibidor de migração de macrófagos in vitro (Bloom \& Bennett, 1966; David, 1966).

Estudos ao longo das duas últimas décadas mostraram que MIF é uma importante proteína pró-inflamatória e imunoreguladora que está relacionada a patogenicidade de inúmeras doenças como a sepse, artrite reumatóide, cancro e a esclerose múltipla, havendo uma correlação entre os níveis dessa proteína e a severidade dessas patologias (Calandra et al., 2000; Yabunaka et al., 2000; Calandra, 2003; Santos e Morand, 2006; Bucala e Donnelly, 2007; Hoi et al., 2007; Radstake e Bucala, 2007; Xu et al., 2008;). Além disso, foi observado que esta proteína é expressa sob condições fisiológicas em uma enorme variedade de tecidos e tipos celulares (El-Turk et al., 2008), incluindo neurônios, células T, eosinófilos, fibroblastos (Bacher et al., 1996; Nishibori et al., 1996), assim como monócitos e macrófagos (Calandra \& Roger, 2003). Ainda, a MIF é secretada pela glândula pituitária anterior em resposta a tensão sistêmica ou em resposta a baixas concentrações de glicocorticóides (Bernhagen et al., 1993; FingerleRowson et al., 2003).

O MIF está envolvido em uma variedade de processos celulares, incluindo regulação transcricional de produtos gênicos inflamatórios (Calandra, 2003), controle do ciclo celular (Pyle et al., 2003; Takahashi et al., 1999), modulação da proliferação celular e diferenciação (Kleeman et al., 2000), regulação da atividade de glucocorticóides (Calandra et al., 1995) e inibição de p53 (Fingerle-Rowson et al., 2003). 
Experimentos para isolar o MIF nativo foram ineficientes, já que seu nível de expressão é baixo (Zerovnik et al., 1999) e, assim, a seqüência codificadora dessa proteína foi clonada pela primeira vez (Weiser et al., 1989) e a expressão em células COS resultaram na proteína solúvel. A purificação rendeu o MIF recombinante com atividade biológica, o que permitiu que estudos fossem realizados a respeito da estabilidade, enovelamento e propriedades espectroscópicas desta proteína globular com importantes funções fisiológicas (Weiser et al., 1989). Estudos identificaram o MIF de mamíferos como um potente ativador de macrófagos e seu papel como mediador celular da defesa imunológica (Weiser et al., 1991).

Os organismos patogênicos têm adotado uma variedade de estratégias para evadir ou modificar as respostas imunes, visando sua sobrevivência no hospedeiro. Ortólogos de MIF foram encontrados em diversos parasitas como Brugia malaya, Plasmodium falciparum, Plasmodium berghri, Trichinella spiralis, Eimeria acervulina, Ancylostoma ceylanicum, Leishmania major (Pastrana et al., 1998; Tan et al., 2001; Zang et al., 2002; Augustijn et al., 2007; Cho, et al., 2007; Cordery et al., 2007; Miska et al., 2007; Richardson, et al., 2009) e Amblyomma americanum (Jarworski et al., 2001). Acredita-se que a produção dessas ortólogas de MIF desempenha um importante papel na relação parasita/hospedeiro (Jarworski et al., 2001). A descrição de MIF em Brugia malayi mostrou que parasitas helmintos podem produzir homólogos de citocinas, os quais podem possuir um potencial de modificar a resposta imune do hospedeiro para promover a sobrevivência do parasita (Pastrana et al., 1998).

O MIF vem sendo estudado em camundongos infectados por diferentes patógenos Trypanossoma cruzi, Pseudomonas aeruginosa, Listeria monocytogenes, Salmonella serovar, Taenia crassicep, já que foi observado que MIF de mamíferos participam de um papel crítico na regulação da resistência do hospedeiro ao organismo 
patogênico (Bozza et al., 1999; Koebernick et al., 2002; Rodriguez-Souza et al., 2003; Reyes et al., 2006; Sashinami et al., 2006). Esses estudos demonstraram que o fator MIF pode atuar positivamente ou negativamente nas infecções, dependendo do organismo patogênico. Em camundongos, por exemplo, MIF foi o principal mediador liberado pela glândula pituitária em resposta ao lipopolissacarídeo (LPS), e amplificou a ação fatal do fator de necrose tumoral alfa (TNF- $\alpha$ ), causando endotoxemia letal (Bozza et al., 1999; Calandra et al., 2000). Verificou-se que o MIF de camundongos, na presença de TNF- $\alpha$ endógeno, ressalta a produção de óxido nítrico em macrófagos induzindo a morte de $L$. major in vitro (Rodríguez-Sousa et al., 2003). Observou-se também que em camundongos infectados com L. major, tanto BALB/c suscetíveis quanto em C57BL/6 resistentes à infecção, expressaram alto nível de mRNA do MIF em seus nodos linfáticos (Juttner et al., 1998). Além disso, os camundongos deficientes de MIF $\left(\mathrm{MIF}^{-/}\right.$) foram suscetíveis à infecção por L. major e desenvolveram lesões cutâneas maiores e mais graves do que os camundongos selvagens com $\mathrm{MIF}^{+/+}$, pois a atividade leishmanicida do macrófago foi prejudicada, o que sugere um papel protetor da MIF do hospedeiro nos casos de leishmaniose cutânea (Satoskar et al., 2001). Do mesmo modo, os camundongos $\mathrm{MIF}^{-/-}$foram susceptíveis à infecção por $T$. cruzi, com a redução na produção de citocinas pró-inflamatórias, sugerindo que MIF participa na ativação do sistema imune inato, e induz o início das respostas inflamatórias contra a infecção, participando na ativação do sistema imune (Reyes et al.,2006). Resultados similares foram relatados na infecção com Taenia crassicep na ausência de MIF em camundongos $\mathrm{MIF}^{-/-}$(Rodriguez-Souza et al., 2003).

O sequenciamento do genoma de Leishmania major apresentou duas seqüências de 342 nucleotídeos que possuem identidade significativa com o MIF de mamíferos (Ivens et al., 2005). A sequência predita da proteína para os dois ortólogos do MIF 
(LmMIF1 e LmMIF2) contém 114 aminoácidos, massa molecular de 12,5kDa, coeficiente de extinção molar 8640, ponto isoelétrico igual a 7,8 (Calandra \& Roger, 2003) e apresentaram homologia estrutural e funcional quando comparados ao MIF humano (Ivens et al., 2005; Kamir et al., 2008).

A presença de duas MIFs em Leishmania não é comum, já que em muitos ortólogos são encontrados apenas uma MIF, o que sugere função única para estas proteínas (Richardson et al., 2009.) LmMIF1 apresenta $20 \%$ de identidade em sua sequência quando comparada com a MIF humana e de camundongos e identidade seqüencial entre 58-99\% quando comparada a MIF de outras espécies de Leishmania (Richardson et al., 2009).

MIF foi identificada através de um único "spot" em gel 2D através de um estudo do conteúdo solúvel da fração vesicular de espécies de Leishmania amazonensis. A identificação foi feita a partir da análise do perfil de massas peptídicas, obtidas com análises de espectrometria de massa (MALDI-TOF) usando o banco de dados do genoma de L. major, já que o genoma desta espécie ainda não foi completamente elucidado. A proteína apresentou peso molecular de $12,5 \mathrm{kDa}$ e ponto isoelétrico em $\mathrm{pH}$ 8.2. (de Oliveira, 2006).

Estudos realizados em 2008 confirmaram a expressão dos genes Lm1740MIF (LmMIF1) e Lm1750MIF ( LmMIF2) in vivo por PCR em tempo real que mostrou que a expressão do gene $L m M I F$ foi mais elevada na forma promastigota do parasita. Além disso, a expressão do LmMIF2 foi mais elevada nas duas formas de vida do parasito, mostrando aproximadamente 3 vezes maior expressão em promastigotas (Kamir et al., 2008). Funcionalmente LmMIF1 interage com o MIF receptor, CD74, e exibe uma atividade anti-apoptótica que pode facilitar a persistência intracelular de Leishmania em macrófagos. LmMIF1 mostrou interação significativa com o receptor de MIF, CD74 
$\left(\mathrm{Kd}=2,9 \times 10^{-8} \mathrm{M}\right)$. Assim como o de mamífero, $L m \mathrm{MIF} 1$ induziu a ativação da quinase MAP ERK1/2 na forma CD74-dependente e inibiu a ativação da apoptose induzida de macrófagos. A capacidade de $L m M I F 1$ em inibir apoptose pode facilitar a persistência de Leishmania dentro do macrófago e contribuir para evasão da destruição imunológica (Kamir et al., 2008).

Duas atividades catalíticas foram descritas para o Fator Inibitório de Migração de Macrófagos, a tautomerase e a tiol oxidoredutase (Kleeman et al., 1998; Flaster et al., 2007). MIF atua como uma enzima que catalisa a tautomerização de vários substratos in vitro (Swope e Lolis, 1999), interconvertendo a forma ceto para enol dos extratos Ddopacromo em ácido 5,6-diidroxi-indol-2-carboxílico (Rosengren et al., 1996) e fenilpiruvato (ou hidroxifenilpiruvato) (Rosengren et al., 1997; Lubetsky et al., 1999). Como uma tiol-proteína oxidorredutase, MIF catalisa a redução da insulina e 2hidroxietildissulfeto (hed) pela glutationa (gsh) e dihidrolipoamida (dhl) (Kleemann et al., 1998). Essa atividade é usada para confirmar o enovelamento característico do MIF e para verificar a conservação do resíduo Pro-2, que se encontra em um ambiente hidrofóbico, como foi observado em experimentos de raios-X (Bendrat et al., 1997; Stamps et al., 1998; Lubetsky et al., 1999) e os aminoácidos da região C-terminal que são essenciais para a atividade tautomerásica dessa proteína (Pastrana et al., 1998). O fator MIF também mostrou ter atividade oxidoredutase em ensaios com insulina envolvendo o motivo CXXC da proteína (Kleemann et al., 1998), apesar de não haver uma relevância biológica conhecida para estas atividades.

O alinhamento entre as sequências das proteínas de MIF1 e MIF2 de L. major, B. malayi, humana e de camundongos revelam a conservação nas MIFs de L.major de uma prolina na região N-terminal. (Kamir et al., 2008) LmMIF1 tautomerizou o substrato metilester-D-dopacromo in vitro, mas a atividade específica para essa reação 
foi de 13 vezes menor do que a MIF humana. Foi observada uma atividade tautomerásica muito baixa para esta proteína utilizando o substrato phidroxifenilpiruvato (Kamir et al., 2008). Um estudo da atividade tautomerásica da proteína MIF1 com inibidor do sítio catalítico da MIF humana, ISO-1 (Lubestsky et al., 2002), revelou que a atividade da MIF1 não foi inibida pelo ISO-1 (Kamir et al., 2008). Assim, esse resultado indicou possível interação seletiva do inibidor com o sítio de tautomerização da MIF humana (Kamir et al., 2008). O motivo CxxC, relacionado à atividade de oxidoredutase da MIF humana (resíduos55 a 59), não foi encontrada em nenhuma das MIFs de Leishmania (Richardson et al., 2009).

Foram elucidadas as estruturas cristalográficas de MIF de oito espécies, incluindo humana (Sun et al., 1996), de ratos (Taylor et al., 1999), sapos (Suzuki et al., 2004) e dos parasitas Brugia malayi (Zang et al., 2002) e L.major (Kamir et al., 2008) e todas essas estruturas são triméricas no cristal. A estrutura do MIF humano (Sun et al., 1996; Kato et al., 1996; Sugimoto et al., 1996) e de camundongos (Suzuki et al., 1996) foram resolvidas por cristalografia de raios- $\mathrm{X}$, os cristais apresentam uma alta homologia estrutural com uma pequena diferença na região $\mathrm{C}$ terminal. A parte central da estrutura monomérica do MIF humano consiste de uma mistura de quatro $\beta$-folhas com duas $\alpha$-hélices antiparalelas, as $\alpha$-hélices estão rodeadas por uma $\beta$-folha de um lado e do outro lado por duas $\beta$-folhas (Sugimoto et al.,1996). As estruturas obtidas por raios-X mostram que a estrutura secundária do monômero tem um motivo $\beta \alpha \beta \beta \beta \alpha \beta$, com $\beta$ elementos, $\beta_{1}, \beta_{2}, \beta_{4}$ e $\beta_{5}$ formando a folha central. Dentro da folha $\beta$ central, duas folhas $\beta$ estão paralelas, sendo uma delas $\mathrm{N}$-terminal, enquanto que as folhas $\beta$ conectadas por uma $\alpha$-hélice são alinhadas de maneira antiparalela (Muhlhahn et al.,1996). Três monômeros do MIF se oligomerizam formando um trímero, estabilizado por ligações de hidrogênio e com folhas $\beta$ extras na região $C$ terminal, proporcionando 
uma estrutura mais simétrica. A estrutura do trímero consiste de sete folhas $\beta$ rodeadas por seis $\alpha$ hélices que se envolvem para formar um barril, contendo um canal acessível ao solvente (Sugimoto et al., 1996). O trímero é estabilizado pelas interações entre resíduos da $\alpha$ hélice de uma das subunidades (73-81) (NKSKC) e resíduos da região C terminal de outra (111-113) (NST) (Sun et al., 1996).

A fim de compreender a relação entre MIF humano e MIF de L. major, a nível molecular, a estrutura cristalina da proteína $L m M I F 1$ foi obtida em uma resolução de $1,03 \AA$.
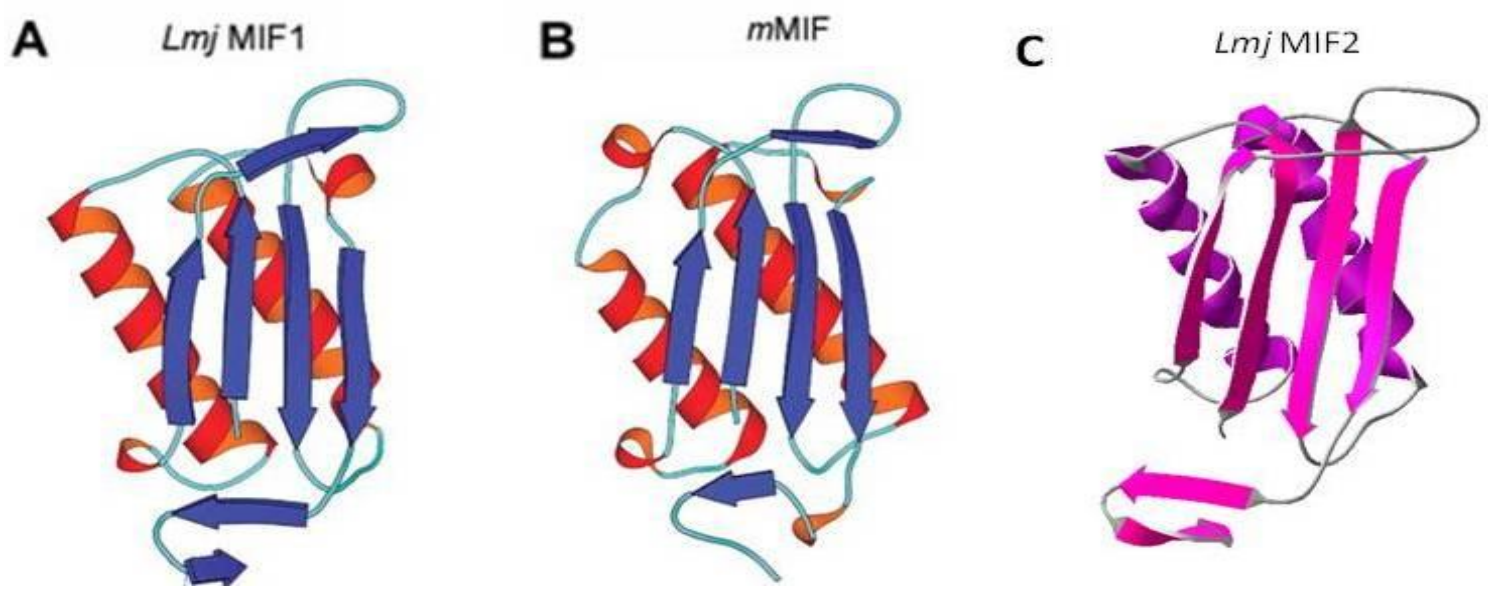

Figura 3: Estrutura conservada entre LmMIF1, mMIF (mamífero) e LmMIF2. Representação esquemática da forma monomérica, com elementos da estrutura secundária folhas $\beta$ mostrados em azul em A e B e rosa em C, e, $\alpha$-hélices, em vermelho, para A e B e em roxo para $\mathrm{C}$.

Esta estrutura consiste de um protômero por unidade assimétrica que forma um trímero com dois protômeros de unidades assimétricas adjacentes (Kamir et al., 2008) (Figura 3). A sobreposição dos átomos $\mathrm{C} \alpha$ de cada monômero da MIF humana e da LmMIF1 resultou em desvio médio de 1,8 $\AA$ (Kamir et al., 2008). A topologia da LmMIF1 foi similar a MIF de humanos e a MIF de camundongos (Sun et al., 1996; Suzuki et al., 1996), porém existem características diferentes no sítio catalítico (Kamir et al., 2008). Uma delas é a nítida diferença no potencial eletrostático, relativo a proteína humana, devido à proximidade da $\mathrm{Glu}^{65}$ do protômero A com o sítio catalítico; 
e as outras foram as três substituições de aminoácidos na região catalítica N-terminal (Kamir et al., 2008).

A substituição da Ile $^{67}$ pela Leu em LmMIF1 foi menos significativa, pois o contato do substrato nesta região envolvia uma ligação de hidrogênio. Já as substituições da $\operatorname{Tyr}^{98}$ e da $\mathrm{Asn}^{100}$ pelos resíduos hidrofóbicos Phe e Leu, respectivamente, eliminaram duas ligações de hidrogênio que na proteína humana interagiam com o substrato (Kamir et al., 2008). Desse modo, as diferentes características no sítio catalítico da $L m M I F 1$ resultaram em menor interação do substrato com o sítio ativo da proteína e, conseqüentemente, a atividade tautomerásica foi reduzida. Por outro lado, a região N-terminal e a região hidrofóbica em MIF de outros organismos apresentaram-se conservadas (Kamir et al., 2008).

Quando sobrepostos, os monômeros de MIF LmMIF1 e LmMIF2 diferem entre si através dos resíduos 100-107 e 30-37, que ligam o final da cauda C-terminal da primeira $\alpha$-hélice com a segunda $\beta$-folha (Richardson et al., 2009). Uma comparação entre MIF de L. major e MIF de mamíferos mostrou duas regiões com diferenças estruturais, a primeira está relacionada aos resíduos 13-31 que formam a primeira $\alpha$ hélice em ambas estruturas de LmMIFs. Em MIF de mamíferos, esta $\alpha$-hélice é significativamente menor. Na posição 15, MIF de mamíferos apresentam uma prolina, enquanto MIFs de L. major possuem uma Lisina. Esta mudança não conservativa favoreceu para uma mudança na estrutura dos monômeros (Richardson et al., 2009). A segunda região que apresenta diferenças estruturais está na superfície do trímero, perto do sítio de atividade tautomerásica e compreende a região entre os resíduos 64-71, que apesar de terem sequências diferentes entre as MIFs de L. major tem conformações muito parecidas, porém quando comparados ao MIF de camundongos as estruturas tridimensionais mostram que os átomos desta região da cadeia apresentam $6 \AA$ de 
diferença. Estas diferenças permitem que o canal de acesso ao solvente das MIFs de $L$. major sejam mais estreitos (Richardson et al., 2009) (Figura 4).
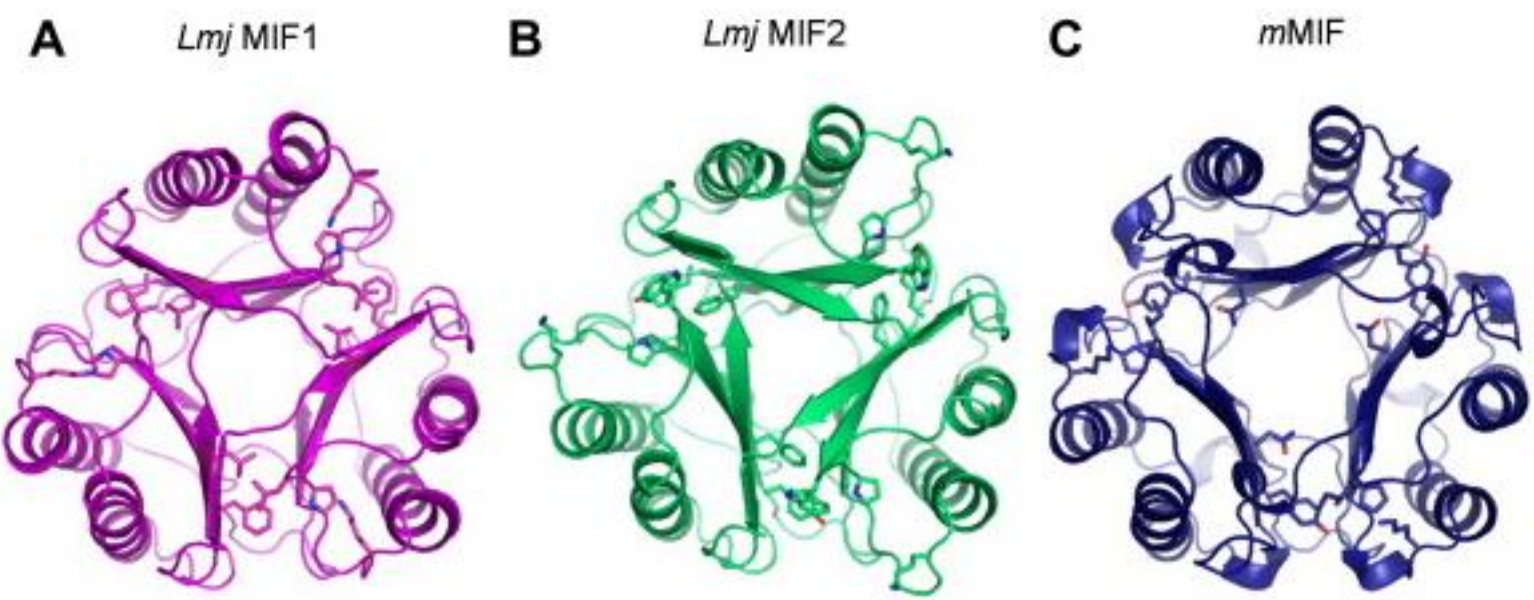

Figura 04: Estrutura conservada entre $L m$ MIF1, LmMIF2 e mMIF, representação esquemática da forma trimérica.

Com relação a superfície eletrostática observa-se que LmMIF2 apresenta uma carga extremamente positiva na superfície do trímero, o que é semelhante as MIFs de mamíferos, a $L m M I F 1$, por sua vez, apresenta a superfície predominantemente negativa (Richardson et al., 2009).

O estado de oligomerização do MIF continua contraditório e os resultados mudam de acordo com a técnica de análise empregada. Análises de RMN do MIF humano e de ultracentrifugação analítica com MIF de ratos foram realizadas e os resultados apontam para a formação de estruturas diméricas (Nishihira et al., 1998; Mühlhahn, et al., 1996). Análises de filtração em gel sugerem que o MIF humano é um dímero enquanto o MIF bovino é um monômero (Zeng et al., 1993; Galat et al., 1993). Por meio de análises de filtração em gel e SDS-PAGE, o MIF humano foi encontrado em concentrações fisiológicas como uma mistura de monômeros, dímeros e trímeros, apresentando maior concentração de monômeros e dímeros. Segundo Mischke (1998), o estado de oligomerização de MIF em solução é determinado de acordo com a 
concentração de proteína, pela sinalização através da ativação do receptor ou da ligação ao substrato que pode favorecer um estado de oligomerização em relação ao outro.

A alta homologia estrutural entre as MIFs humana e a de L. major indica que esta proteína pode ter um papel importante na relação parasita/hospedeiro, pois pode existir a possibilidade do MIF do parasita interagir com os alvos do MIF humano. Em vista disso, o estudo de estrutura e função da proteína LmMIF2 pode contribuir para elucidar os aspectos envolvidos no mecanismo adotado pela Leishmania major para evadir do sistema imune do hospedeiro, uma vez que já foi sugerido uma modulação de sistemas imunológicos de hospedeiros por outros parasitas que expressam a MIF durante seu ciclo de vida. 


\section{Objetivos}




\section{Objetivos}

\subsection{Objetivo Geral}

Realizar mutações sítio-dirigidas na proteína recombinante Fator Inibitório de Migração de Macrófagos de L. major (LmMIF2) e investigar o efeito dessas mutações na atividade da proteína e na manutenção de sua estrutura.

\subsection{Objetivos Específicos}

1) Efetuar mutações sítio-dirigidas da sequiência codificadora da $\operatorname{LmMIF}$, clonada no pET21b, para produção dos mutantes (P2G, K34E, W66L, W108F e $\Delta 104-113)$;

2) Expressar as proteínas mutantes em E. coli e purificá-las por cromatografia de afinidade;

3) Avaliar as estruturas secundária, terciária e quaternária do MIF recombinante e dos mutantes por dicroísmo circular, fluorescência intrínseca do triptofano e filtração em gel;

4) Realizar ensaios de inibição da migração dos macrófagos para avaliar o efeito das mutações na atividade funcional da proteína recombinante $L m \mathrm{MIF}$. 
3. Mlateriais e Mlétodos 


\section{Materiais e Métodos}

\subsection{Mutagênese sítio-dirigida por Reação em cadeia da Polimerase (PCR)}

A mutagênese sítio-dirigida foi realizada utilizando-se a técnica da Reação em Cadeia da Polimerase - PCR (Nelson e Long, 1989), que permitiu a introdução de uma mutação em regiões específicas da molécula de DNA de fita dupla, utilizando-se oligonucleotídeos específicos ("primers”) e um molde que possui o gene clonado. A PCR ocorreu em um termociclador (Eppendorf - Modelo MasterCycler) que através de sucessivas mudanças de temperatura direciona as três etapas da reação: desnaturação, anelamento e extensão. Este ciclo é repetido por várias vezes até que aproximadamente 500ng do DNA a ser amplificado seja obtido.

A mutagênese sítio-dirigida foi feita utilizando-se o vetor pET21b contendo a seqüência codificadora da LmMIF2 de Leishmania major (pET21bMIF2) e ocorreu em três etapas: (1) inserção da mutação desejada através de amplificação de um fragmento usando dois oligonucleotídeos. Nessa etapa da reação foram utilizados a mistura de $10 \mu \mathrm{L}$ de tampão 10X da PCR (200 mM Tris - pH 8.4, $500 \mathrm{mM} \mathrm{KCl}), 10 \mu \mathrm{L}$ de $\mathrm{MgCl}_{2}$ 50mM, $10 \mu \mathrm{L}$ de dNTPs $25 \mathrm{mM}$ (dATP, dCTP, dGTP, dTTP), 2,5 $\mu \mathrm{L}$ do MUT-MIF primer interno mutado (10 pmol), $2,5 \mu \mathrm{L}$ do oligo EXT1 - externo plasmidial $5^{\prime}$ (10 pmol), $0,6 \mu \mathrm{L}$ do vetor pET21b + LmMIF2 linearizado (300ng), 0,5 $\mu \mathrm{L}$ da enzima Taq polimerase Platinum ${ }^{\circledR}$ (Invitrogen) $5 \mathrm{U}_{\mu} \mu \mathrm{L}^{-1}$, completando o volume com água estéril para $100 \mu \mathrm{L}$, que seguiu os seguintes passos: $94^{\circ} \mathrm{C}$ por $4 \min , 94^{\circ} \mathrm{C}$ por $1 \mathrm{~min}, 45^{\circ} \mathrm{C}$ por $1 \mathrm{~min}$ e $72^{\circ} \mathrm{C}$ por $1 \mathrm{~min}$. Os três últimos passos foram repetidos por 30 vezes. $\mathrm{O}$ fragmento com o tamanho específico para cada mutação gerada foi analisado em gel de agarose $1 \%$, corado com brometo de etídio $\left(0,05 \mu \mathrm{g} \cdot \mathrm{mL}^{-1}\right)$, com posterior extração e 
purificação utilizando o Mini Kit Agarose Gel Extract (Axigen). Na etapa (2) foi realizada a extensão do fragmento obtido na etapa anterior ("mega primer") usando como fita molde o vetor pET21bMIF2 para que se obtivesse uma sequência mutada completa. A reação foi realizada com $10 \mu \mathrm{L}$ de tampão $10 \mathrm{X}$ da PCR $(200$ mM Tris - pH 8.4, $500 \mathrm{mM} \mathrm{KCl}), 10 \mu \mathrm{L}$ de $\mathrm{MgCl}_{2} 50 \mathrm{mM}, 10 \mu \mathrm{L}$ de dNTPs $25 \mathrm{mM}$ (dATP, dCTP, dGTP, dTTP), $2 \mu \mathrm{L}$ do mega primer, $0,6 \mu \mathrm{L}$ do vetor pET21b + MIF linearizado (300ng), $0,5 \mu \mathrm{L}$ da enzima Taq DNA Polimerase \& Platinum ${ }^{\circledR} 5 \mathrm{U}_{\mathrm{H}} \mu \mathrm{L}^{-1}$, o volume final de $100 \mu \mathrm{L}$ foi completado com água estéril. Esta etapa foi realizada sob as seguintes condições: $96^{\circ} \mathrm{C}$ por $2 \mathrm{~min}, 96^{\circ} \mathrm{C}$ por $1 \mathrm{~min}, 55^{\circ} \mathrm{C}$ por $30 \mathrm{seg}$ e $72^{\circ} \mathrm{C}$ por $1 \mathrm{~min}$. Os três últimos passos foram repetidos 5 vezes. A reação seguinte (3) constituiu-se da amplificação do fragmento completo com um oligonucleotídeo externo à 5' (primer EXT2) e um oligonuclotídeo externo à 3' (T7 terminator) da fita estendida para a obtenção do fragmento mutado completo. Esta etapa da reação foi realizada adicionando-se à etapa seguinte 100pmol de EXT2 e 100pmol de T7terminator utilizando-se as mesmas condições experimentais da primeira etapa: $94^{\circ} \mathrm{C}$ por 4 min, seguidos por 30 ciclos de $94^{\circ} \mathrm{C}$ por $1 \mathrm{~min}, 45^{\circ} \mathrm{C}$ por $1 \mathrm{~min}$ e $72^{\circ} \mathrm{C}$ por $1 \mathrm{~min}$.

Na Figura 05 estão apresentadas todas as etapas envolvidas no processo de mutagênese sítio-dirigida e, em seguida, encontram-se os oligonucleotídeos utilizados. 


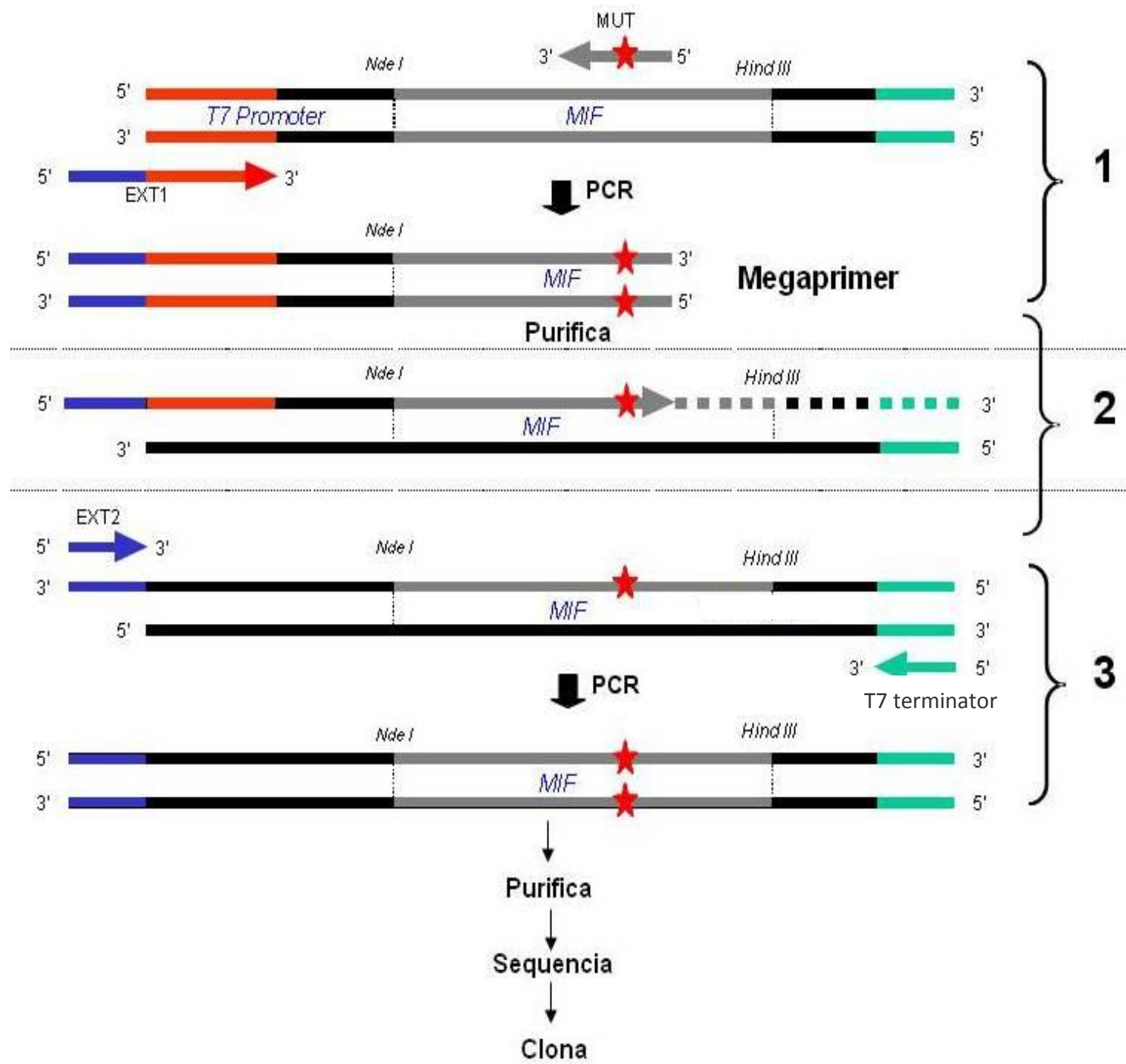

Figura 05: Esquema ilustrativo de mutagênese sítio-dirigida por reação em cadeia de polimerase. MUT, EXT1, EXT2, T7 terminator representam oligonucleotídeos complementares às seqüências moldes; Nde I e Hind III representam as posições dos sítios de restrição enzimáticos.

Nas reações foram utilizados os seguintes oligonucleotídeos:

EXT1 (5' para 3'): CGA AAG CAG AGA AAA GAT GCC TAA TAC GAC TCA

CTA TAG GG

EXT2 (5' para 3'): CGA AAG CAG AGA AAA GAT GCC

T7 terminator: TAT GCT AGT TAT TGC TCA 
Os oligonucleotídeos mutagênicos estão apresentados na Tabela 01. Os fragmentos de tamanhos específicos foram extraídos e purificados do gel de agarose $1 \%$ utilizando o Mini Kit Agarose Gel Extract (Axigen).

Tabela 01: Oligonucleotídeos para introduzir as mutações no MIF

\begin{tabular}{|c|c|}
\hline MUTANTE & OLIGONUCLEOTÍDEOS (5' para 3') \\
\hline W108F & GTT AGT GCC GTT GAA GCC GCA \\
\hline K34A & 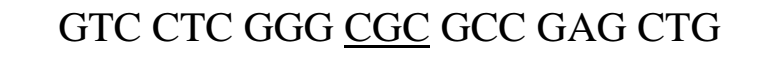 \\
\hline W66L & 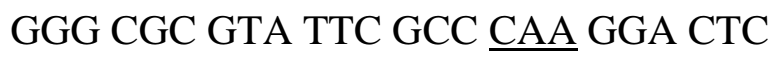 \\
\hline P2G & CAC CTA AGC ATA TGG GCT TTC \\
\hline$\Delta 103-113$ & AAG CTT GTG CTT GCC ACT GTA G \\
\hline
\end{tabular}

\subsection{Preparação do Vetor pET21b}

$\mathrm{O}$ vetor pET21b (Novagen) é um vetor de 5442pb que possui uma região projetada para expressar proteínas com cauda de histidina na região $\mathrm{C}$ terminal. $\mathrm{O}$ vetor e as amostras foram digeridas com as enzimas de restrição fast digest NdeI (10U) e HindIII (10U) (Fermentas) por $2 \mathrm{~h}$ a $37^{\circ} \mathrm{C}$ e a inativação das enzimas foi feita submetendo-as à uma temperatura de $80^{\circ} \mathrm{C}$ por 10 min para posterior ligação com o vetor de clonagem pET21b. 


\subsection{Ligação do Fragmento Mutado ao Vetor pET21b}

$\mathrm{O}$ vetor pET21b+ possui uma sequência de nucleotídeos (18pb) que codifica uma cauda de 6 histidinas na região C-terminal das proteínas traduzidas a partir do gene clonado no "poly linker". A utilização de vetores contendo seqüência para a cauda de histidina oferece vantagens para a posterior purificação da proteína com resina de $\mathrm{Ni}^{2+}$, facilitando a extração da proteína de interesse do extrato protéico. Além de possuir uma sequência referente ao operon da lactose, lac I, para a indução de expressão por IPTG (isopropil-ß-D-tiogalactopiranosídeo) e o gene que confere resistência ao antibiótico ampicilina.

Foi utilizada uma reação com volume final de $20 \mu \mathrm{L}$ para ligar o fragmento mutado ao vetor pET21b. Adicionou-se água estéril, $4 \mu \mathrm{L}$ do tampão $5 \mathrm{X}$ de T4 DNA ligase (Tris- $\mathrm{HCl} 250 \mathrm{mM}, \mathrm{MgCl}_{2} 50 \mathrm{mM}$, ATP $5 \mathrm{mM}$, DTT $5 \mathrm{mM}$ e $25 \%$ peso/volume de polietileno glicol-8000) (Fermentas), o fragmento mutado e o vetor na proporção de 3:1 (fragmento:vetor), devidamente digeridos e dosados, totalizando um volume de 19 $\mu \mathrm{L}$. Em seguida, a reação foi incubada por 5 min à $45^{\circ} \mathrm{C}$ e, posteriormente, acrescentouse $1 \mu \mathrm{L}$ da enzima T4 DNA ligase $\left(5 \mathrm{U} \mu \mathrm{L}^{-1}\right)$ (Fermentas). A reação foi submetida à temperatura ótima de ação da T4 DNA ligase de $14^{\circ} \mathrm{C}$ por 18 horas.

\subsection{Preparação de células $E$. coli DH5a competentes}

As células de E. coli linhagem DH5a foram preparadas de acordo com o método descrito por Hanahan (1983), as quais foram inoculadas em uma placa com meio LuriaBertani sólido (LB - Triptona 10g.L $\mathrm{L}^{-1}$, Cloreto de Sódio 10g.L $\mathrm{L}^{-1}$, Extrato de Levedura 5g.L $\mathrm{L}^{-1}$ e Agar $15 \mathrm{~g} . \mathrm{L}^{-1}$ ), deixando-as crescer por 12 horas à $37^{\circ} \mathrm{C}$. Em seguida, algumas 
colônias foram lançadas em tubos contendo $5 \mathrm{~mL}$ de meio Luria-Bertani (LB) líquido (Triptona 10g.L ${ }^{-1}$, Cloreto de Sódio $10 \mathrm{~g} . \mathrm{L}^{-1}$ e Extrato de Levedura 5g.L $\mathrm{L}^{-1}$ ) devidamente autoclavado. Estas foram submetidas a agitação de $180 \mathrm{rpm}$, durante $12 \mathrm{~h}$, à $37^{\circ} \mathrm{C}$ para crescimento do pré-inóculo. Retirou-se $1 \mathrm{~mL}$ do meio de cultura para análise do crescimento das bactérias e inoculou-se os outros $4 \mathrm{~mL}$ de cultura em $400 \mathrm{~mL}$ de meio LB, deixando o sistema sob agitação de 180rpm durante 2horas, em seguida, verificouse através de um espectrofotômetro a densidade ótica de cultivo num comprimento de onda de $600 \mathrm{~nm}$, até a $\mathrm{OD}_{600 \mathrm{~nm}}$ atingir 0,3 .

A cultura foi transferida para tubos de polipropileno e os mesmos foram incubados por 5 min no gelo. Centrifugou-se a solução por 10 min a $3000 \times g$ (Sorvall RC 5B) à $4^{\circ} \mathrm{C}$. No fundo do tubo foi observado a formação de um precipitado. $\mathrm{O}$ sobrenadante foi descartado e o material sedimentado foi ressuspendido em $100 \mathrm{~mL}$ de tampão gelado de $\mathrm{Ca}^{2+} /$ Glicerol $\left(\mathrm{CaCl}_{2} 60 \mathrm{mM}\right.$, PIPES - 1,4-Piperazin-bisethansulfonsaeure) - $10 \mathrm{mM}$ e glicerol 15\%). As células foram centrifugadas novamente por $10 \mathrm{~min}, 3000 \times g, 4^{\circ} \mathrm{C}$ e ressuspendidas em $100 \mathrm{~mL}$ do tampão $\mathrm{Ca}^{2+} /$ glicerol e, em seguida, as células foram incubadas no gelo por 30 min. A solução foi submetida a uma nova centrifugação por $10 \mathrm{~min}, 3000 \times g, 4^{\circ} \mathrm{C}$ e o precipitado foi ressuspendido em $12 \mathrm{~mL}$ do tampão $\mathrm{Ca}^{2+} /$ glicerol gelado. As células foram distribuídas em alíquotas de $50 \mu \mathrm{L}$ e estocadas à $-70^{\circ} \mathrm{C}$.

\subsection{Transformação em E. coli DH5a}

As células competentes da linhagem DH5 $\alpha$ foram utilizadas para transformação com o vetor mais o inserto - pET21bLmMIF2 (controle positivo), pET21b sem inserto (controle negativo) e pET21bLmMIF mutante (Sambrook e Russell., 2001). Foram 
adicionadas $50 \mu \mathrm{L}$ de células à 100 ng do DNA, a solução foi incubada por 20 min no gelo e, em seguida, foi submetida a um choque térmico de 90 segundos, à $42^{\circ} \mathrm{C}$ para a inserção do DNA a bactéria. Em seguida, a solução foi colocada novamente no gelo por

2 min. Adicionou-se às células $1 \mathrm{~mL}$ de meio de cultura $\mathrm{LB}$ (Triptona $10 \mathrm{~g} \cdot \mathrm{L}^{-1}, \mathrm{NaCl}$ 10g. $\mathrm{L}^{-1}$ e Extrato de levedura $5 \mathrm{~g} . \mathrm{L}^{-1}$ ), glicose $10 \mathrm{mM}$ e $\mathrm{MgCl}_{2} 10 \mathrm{mM}$ deixando-as regenerar por $1 \mathrm{~h}$ à $37^{\circ} \mathrm{C}$ sob agitação de $180 \mathrm{rpm}$. As células transformadas foram centrifugadas a $5000 \times g$ por $3 \mathrm{~min}, 900 \mu \mathrm{L}$ do sobrenadante foi descartado e as células foram ressuspendidas no meio LB restante. Em seguida, as células transformadas foram aplicadas em placas de Petri com meio LB sólido (15g.L $\left.{ }^{-1}\right)$ contendo $100 \mu \mathrm{g} \cdot \mathrm{mL}^{-1}$ de ampicilina (Sigma) e mantidas em estufa de cultura a $37^{\circ} \mathrm{C}$ por 12 horas.

\subsection{PCR de Colônia}

Após 12 horas de crescimento dos transformantes, metade de cada colônia crescida nas placas com LB sólido foram submetidas à técnica de PCR, que permitiu verificar se havia ou não inserto no plasmídeo. A PCR ocorreu em termociclador, utilizando-se 2,5 $\mu \mathrm{L}$ de tampão 10X PCR $(200 \mathrm{mM}$ tris $-\mathrm{pH} 8.4+500 \mathrm{mM} \mathrm{KCl}), 2,5 \mu \mathrm{L}$ de $\mathrm{MgCl}_{2}$ 50mM, 2,5 $\mu \mathrm{L}$ de dNTPs 25mM (dATP, dCTP, dGTP, dTTP), 0,5 $\mu \mathrm{L}$ de T7 terminator, $0,5 \mu \mathrm{L}$ de $\mathrm{T} 7$ promoter e $0,6 \mu \mathrm{L}$ de taq DNA polimerase recombinante (Promega). Completou-se o volume da solução para $25 \mu \mathrm{L}$ com água estéril. As condições em que a reação ocorreu foram: $1-94^{\circ} \mathrm{C}$ por $4 \mathrm{~min}, 2-94^{\circ} \mathrm{C}$ por $1 \mathrm{~min}, 3-$ $45^{\circ} \mathrm{C}$ por 1 min e $4-72^{\circ} \mathrm{C}$ por $1 \mathrm{~min}$. As etapas 2 a 4 foram repetidas 30 vezes. Após o término da reação, a temperatura foi estabilizada a $4^{\circ} \mathrm{C}$. Os fragmentos de tamanho igual ao gene ao fragmento contendo o LmMIF2 foram observados no gel de agarose $1 \%$ e selecionados para posterior extração do DNA. 


\subsection{Extração do DNA de MIF mutante de células DH5a de E. coli}

As colônias de resultado positivo no PCR foram lançadas em tubos com $5 \mathrm{~mL}$ de meio LB líquido e antibiótico (ampicilina $100 \mu \mathrm{g} \cdot \mathrm{mL}^{-1}$ ) para extração do DNA plasmidial por lise alcalina (Sambrook e Russell., 2001). Estas colônias foram submetidas a agitação de $180 \mathrm{rpm}$, durante $12 \mathrm{~h}$, a $37^{\circ} \mathrm{C}$ para crescimento. Após esse período a cultura foi centrifugada por $3 \mathrm{~min}$ a $1000 \times g$, com posterior descarte do sobrenadante. O precipitado foi ressuspendido em tampão GET (Tris $25 \mathrm{mM}$ pH8,0; glicose 50mM; EDTA 10 mM) e, em seguida, adicionou-se $200 \mu \mathrm{L}$ de solução de lise ( NaOH 0,5M e solução SDS10\% - dodecil sulfato de sódio, lauril sulfato de sódio, pH 7,2). A solução foi agitada, permaneceu em repouso por 5minutos na bancada e após a lise das células $150 \mu \mathrm{L}$ de acetato de potássio $3 \mathrm{M}$ foram adicionados aos tubos. As amostras foram submetidas a centrifugação por $10 \mathrm{~min}, 10000 \times g$ a $25^{\circ} \mathrm{C}$. O sobrenadante foi transferido para tubos autoclavados e aos mesmos foram adicionados $1 \mathrm{~mL}$ de etanol $100 \%$, deixando os tubos durante 15 min a $-70^{\circ} \mathrm{C}$ para que houvesse precipitação do DNA. Os tubos foram centrifugados por $15 \mathrm{~min}, 10000 \times g$ a $4^{\circ} \mathrm{C}$ e o sobrenadante foi descartado. Adicionou-se $1 \mathrm{~mL}$ de etanol $70 \%$ aos tubos que foram centrifugados por $10 \mathrm{~min}, 12000 \times g$ a $4^{\circ} \mathrm{C}$. Em seguida, o sobrenadante foi descartado novamente e o precipitado foi inserido na estufa por 15 min para que todo o etanol fosse removido dos frascos. Após este procedimento, o precipitado foi ressuspendido em 200 $\mu \mathrm{g} . \mathrm{mL}^{-1}$ RNase A (Sigma) e a solução foi incubada a temperatura de $37^{\circ} \mathrm{C}$ por $2 \mathrm{~h}$. Aos tubos foram adicionados $50 \mu \mathrm{L}$ de fenol (Invitrogen), para extração do DNA. Após agitação vigorosa o tubo foi submetido a centrifugação por 20 min a $10000 \times g$ e a fase aquosa foi cuidadosamente retirada do tubo e precipitada adicionando-se acetato de sódio $3 \mathrm{M}$, pH 5,2 equivalente a 10\% do volume da amostra e etanol absoluto gelado, 3 
vezes o volume da amostra, deixando-os por $15 \min$ a $-70^{\circ} \mathrm{C}$. A amostra foi centrifugada novamente $10 \mathrm{~min} / 10000 \times g$ à $4^{\circ} \mathrm{C}$. O sobrenadante foi descartado e o precipitado foi ressuspendido, lavado com $1 \mathrm{~mL}$ de etanol $70 \%$, submetido a secagem a $60^{\circ} \mathrm{C}$ e, em seguida, foi ressuspendido em $20 \mu \mathrm{L}$ de tampão TE (Tris 10mM pH8,0; EDTA 1mM).

Para verificar se a ligação entre o vetor e o fragmento mutante de $634 \mathrm{pb}$ ocorreu corretamente foi realizada uma reação de digestão $(20 \mu \mathrm{L})$ com as enzimas $N d e \mathrm{I}$ e HindIII (10U cada).

\subsection{Sequenciamento de nucleotídeos de DNA}

Após a extração do DNA plasmidial foi realizado protocolo para o sequenciamento dos nucletídeos. As reações foram preparadas usando reagente "Big Dye” (ABI Prism BigDye Terminator Cycle Sequencing Ready Reaction v3.1, Applied Biosystems). Misturou-se $1 \mu \mathrm{L}$ de solução "Big Dye" $3 \mu \mathrm{L}$ de tampão 2,5X (200mM Tris, $5 \mathrm{mM} \mathrm{MgCl}$, $\mathrm{pH}$ 9,0), 400ng de DNA, 5 pmoles do oligonucleotídeo iniciador para sequenciamento $5^{\prime}$ ou $3^{\prime}$ do fragmento, completando o volume final de $10 \mu \mathrm{L}$ com água estéril. Em seguida a solução foi submetida as seguintes condições em termociclador: 1$95^{\circ} \mathrm{C}$ por 5 segundos, $2-95^{\circ} \mathrm{C}$ por 10 segundos, $3-50^{\circ} \mathrm{C}$ por 5 segundos e $4-60^{\circ} \mathrm{C}$ por 4 minutos. Os ciclos de 2 a 4 foram repetidos 40x. As amostras foram precipitadas transferindo-se o volume das reações para tubos de maior volume $(1,5 \mathrm{~mL})$, onde foram adicionados $60 \mu \mathrm{L}$ de isopropanol $60 \%$. A solução foi misturada e deixada em repouso sobre a bancada por 20 min a temperatura ambiente $25^{\circ} \mathrm{C}$. Fez-se uma centrifugação por 20 min a $10000 \times g$ e descartou-se o sobrenadante. Ao precipitado foi adicionado $200 \mu \mathrm{L}$ de etanol $70 \%$, centrifugou-se novamente por $20 \mathrm{~min}, 10000 \times g$ descartando-se novamente o sobrenadante. $\mathrm{O}$ precipitado foi submetido à secagem por 1 hora, na 
bancada, para evaporação do etanol. O DNA precipitado foi solubilizdo em tampão “hidi” (Applied Biosystems) e aplicado no seqüenciador automático ABI 3100 (Applied Biosystems). As sequiências obtidas foram comparadas ao banco de dados usando plataforma BLASTN (http://www.ncbi.nlm.nih.gov) para comprovar a presença das mutações.

3.9 Expressão e Purificação de pET21bLmMIF2 e pET21bMIF Mutantes de E. coli linhagem BL21[DE3]pLysS

\subsubsection{Preparo de células BL21 competentes}

As células de E. coli BL21[DE3]pLysS, que foram dispersas em placa de petri, cresceram por $12 \mathrm{~h}$ em meio sólido seletivo HDM (Triptona 15g.L $\mathrm{L}^{-1}$, Extrato de levedura 25g. $\mathrm{L}^{-1}, \mathrm{pH} 7,5$ e $1,5 \%$ de ágar) com o antibiótico cloranfenicol $\left(34 \mu \mathrm{g} \cdot \mathrm{mL}^{-1}\right)$ e ampicilina $\left(100 \mu \mathrm{g} \cdot \mathrm{mL}^{-1}\right)$.

Posteriormente dispersou-se de 2 a 3 colônias de bactéria em $5 \mathrm{~mL}$ de meio HDM líquido (Triptona 15g.L $\mathrm{L}^{-1}$, Extrato de levedura 25g.L ${ }^{-1}, \mathrm{pH} 7,5$ ) as quais foram mantidas sob agitação a $37^{\circ} \mathrm{C}$, por 12 h a $180 \mathrm{rpm}$. O conteúdo do pré-inóculo foi transferido para 400mL de HDM líquido, que foi mantido sob agitação de $180 \mathrm{rpm}$ a $37^{\circ} \mathrm{C}$ até atingir a densidade óptica igual a 0,3 no comprimento de onda de $600 \mathrm{~nm}$. O inóculo foi então submetido à incubação por 5 minutos no gelo, seguido de centrifugação a $5000 \mathrm{~g}, 10$ min a $4^{\circ} \mathrm{C}$. O precipitado foi ressuspendido em $100 \mathrm{~mL}$ de tampão $\left(\mathrm{CaCl}_{2} 60 \mathrm{mM}\right.$, PIPES $10 \mathrm{mM}$ e glicerol $\left.15 \%\right)$, centrifugado por $10 \mathrm{~min}, 5000 \times g$ a $4^{\circ} \mathrm{C}$ e ressuspendido novamente em $100 \mathrm{~mL}$ de tampão. A solução foi mantida sob repouso no gelo por $30 \mathrm{~min}$, centrifugada e ressuspendida em $12 \mathrm{~mL}$ de tampão. As 
células foram aliquotadas com a adição de glicerol 80\%(para qual volume) e estocadas a $-70^{\circ} \mathrm{C}$.

\subsubsection{Transformação rápida de $E$. coli linhagem BL21[DE3]pLysS}

Células competentes BL21[DE3]pLysS permitem a expressão de proteínas de qualquer gene que se encontra sob o controle de um promotor $\mathrm{T} 7$ e não interfere no nível de expressão alcançada após a indução com IPTG. Por meio de uma transformação o plasmídeo pET21b+ LmMIF2 mutante foi introduzido a E. coli linhagem BL21[DE3]pLysS (Sambrook e Russell, 2001).

\subsubsection{Teste de Expressão da $L m$ MIF2 nativa e MIF mutantes}

As colônias de E. coli linhagem BL21 transformadas com pET21b+LmMIF2 e pET21b+MIFmut foram pré-inoculadas em um tubo de ensaio contendo $5 \mathrm{~mL}$ de meio de cultura HDM (triptona 15g. $\mathrm{L}^{-1}$, extrato de levedura 25g. $\mathrm{L}^{-1}, \mathrm{pH} 7,0$ ), antibióticos ampicilina $\left(100 \mu \mathrm{g} \cdot \mathrm{mL}^{-1}\right)$ e cloranfenicol $\left(34 \mu \mathrm{g} \cdot \mathrm{mL}^{-1}\right)$ e $\mathrm{MgSO}_{4} 10 \mathrm{mM}$, sob aquecimento e agitação contínua por $12 \mathrm{~h}$. O teste de expressão foi realizado em volume de $50 \mathrm{~mL}$ da mesma cultura utilizada para fazer o pré-inóculo à $37^{\circ} \mathrm{C}$ e $180 \mathrm{rpm}$. Foi coletado $1 \mathrm{~mL}$ de cultura para verificar a densidade óptica em $600 \mathrm{~nm}$ e quando a $\mathrm{OD}_{600}$ atingiu 0,6 a expressão das proteínas foi induzida com isopropil-ß-D-tiogalactopiranosídeo (IPTG) 0,6mM. Coletou-se alíquotas de $1 \mathrm{~mL}$ de cultura a cada hora de indução durante 6 horas e essas foram centrifugadas a $5000 \times g$, $3 \mathrm{~min}$. O sedimento foi ressuspendido em $100 \mu \mathrm{L}$ de tampão de amostra para SDS-PAGE e o volume correspondente a 0,15 unidades de $\mathrm{OD}_{600}$ foi aplicado em gel de poliacrilamida 15\% (Laemmli, 1970). 


\subsubsection{Preparação dos Extratos de Bactéria}

O precipitado dos $50 \mathrm{~mL}$ de cultura foi ressuspendido em $5 \mathrm{~mL}$ de tampão de Lise (50mM NaH $2 \mathrm{PO}_{4} ; 300 \mathrm{mM} \mathrm{NaCl}$ e 40mM Imidazol, $\left.\mathrm{pH} 8,0\right)$, na presença de fluoreto de fenilmetilsulfonil (PMSF) 4mM. e 1\% Triton 100X. A solução foi sonicada no gelo com 6 pulsos de $30 \mathrm{seg}$ com intervalos de $30 \mathrm{seg}$. Centrifugou-se o extrato da lise por 30 minutos, $10000 \times g$ à $4^{\circ} \mathrm{C}$. O sobrenadante solúvel $(\mathrm{S})$ e o precipitado insolúvel (I), que foi ressuspendido em $5 \mathrm{~mL}$ de tampão de Lise, foram armazenados a $-20^{\circ} \mathrm{C}$.

\subsubsection{Teste de Solubilidade das Proteínas Expressas}

Amostras do extrato solúvel da lise (S) e o extrato sedimentado insolúvel (I), correspondentes a uma absorbância de 0,15 foram submetidas a uma eletroforese em gel desnaturante de poliacrilamida SDS-PAGE $15 \%$ para a análise da presença de LmMIF2 e MIFmut expressa nos extratos obtidos.

\subsubsection{Eletroforese em Gel Desnaturante de Poliacrilamida}

A eletroforese é uma técnica de separação de moléculas que envolve a migração de moléculas em um determinado gel durante a aplicação de uma diferença de potencial. O gel mais comum para proteínas é o de poliacrilamida (PAGE) com adição do detergente dodecilsulfato de sódio (SDS) carregado negativamente. O gel é composto por uma fina malha cruzada composta pelos polímeros de acrilamida e bisacrilamida e uma vez que suas cargas estão igualadas negativamente pelo SDS, as proteínas são separadas pelo seu peso molecular. Dessa forma, as menores moléculas peptídicas 
atravessam a malha mais rapidamente que as de maior tamanho em direção ao pólo positivo do campo elétrico (Nelson \& Cox, 2003).

Para análise em gel de poliacrilamida das proteínas de MIF e mutantes foi feito um gel SDS-PAGE 15\% (Laemmli, 1970), o qual foi preparado por polimerização de uma mistura de acrilamida/bis-acrilamida na razão 29:1, em uma solução tampão (0.0192M Glicina, $0,1 \%$ SDS e $0.025 \mathrm{M}$ Tris- $\mathrm{HCl}, \mathrm{pH} 8.3)$, com $0.05 \%$ de persulfato de amônio e $0.005 \%$ TEMED. A polimerização foi feita em cuba de eletroforese, e as amostras das proteínas submetidas a um campo elétrico de $300 \mathrm{~V}$ e 20mA. Após a corrida de 2h, o gel foi corado com "Comassie R Blue" (Sigma-Aldrich, St. Louis, USA) (Comassie R-250 0,1\%, metanol 50\%, ácido acético 7\%) para a visualização das frações eluídas da coluna de cromatografia e o mesmo foi descorado com uma solução de ácido acético 10\% e etanol 30\%. O marcador de massa molecular utilizado foi LMW (GE lifesciences) (Fosforilase $\mathrm{b}-97 \mathrm{kDa}, \mathrm{BSA}-66 \mathrm{kDa}$, Ovoalbumina $-45 \mathrm{kDa}$, Anidrase Carbônica - 30kDa, Tripsina - 20,1kDa e $\alpha$-lactalbumina - 14,4kDa).

\subsubsection{Expressão da MIF nativa e MIF mutante para purificação}

As proteínas LmMIF2 e MIF mutante foram expressas conforme descrito na seção 3.9.3., entretanto, o inóculo foi feito em 400mL de meio de cultura HDM líquido com $100 \mu \mathrm{g} \cdot \mathrm{mL}^{-1}$ de ampicilina, $34 \mu \mathrm{g} \cdot \mathrm{mL}^{-1}$ de Cloranfenicol e $10 \mathrm{mM} \mathrm{MgSO} 4$ à $37^{\circ} \mathrm{C} \mathrm{e}$ 180rpm até $\mathrm{DO}_{600}=0,6$. A indução foi feita com isopropil- $\beta$-D-tiogalactopiranosídeo (IPTG) 0,6mM, por 5 horas. Posteriormente, a cultura foi centrifugada (Sorval, modelo RC5 Plus) por 10 minutos, a $4^{\circ} \mathrm{C}$ e $6000 \times g$, e o precipitado contendo as bactérias foi ressuspendido em solução de Lise (seção 3.9.4). O precipitado foi sonicado 6 vezes por 
30 segundos com intervalo de 30 segundos no gelo. A solução foi centrifugada novamente por $30 \mathrm{~min}, 12000 \times g$, à $4^{\circ} \mathrm{C}$. $\mathrm{O}$ sobrenadante foi transferido para tubos cônicos e acondicionado no gelo para que, em seguida, as proteínas fossem purificadas.

\subsubsection{Purificação do $r L m M I F 2$ nativa e MIF mutante por cromatografia de afinidade}

A purificação de $r L m M I F 2$ nativa e MIF mutantes foi realizada por cromatografia de afinidade utilizando a resina de Ni-NTA (ácido nitrilotriacético de níquel), que possui como matriz íons níquel ligados à sepharose. O NTA interage com 4 sítios de ligação do íon Níquel, deixando 2 sítios livres para a interação com a cauda de histidina da proteína. Essa interação com íons divalentes é estável em várias condições, o que permite uma maior variação de parâmetros para a purificação da proteína de interesse.

O extrato solúvel da lise das bactérias $(400 \mathrm{~mL})$ foi incubado durante uma hora e meia à $4^{\circ} \mathrm{C}$ a $2 \mathrm{~mL}$ de resina Ni-NTA (Quiagen, Hilden, Alemanha) devidamente equilibrada em tampão de Lise. A resina foi empacotada em coluna de cromatografia $(10 X 1,5 \mathrm{~cm})$ e, em seguida, a solução foi eluída. Coletou-se uma alíquota do conteúdo que não ligou a resina ("Flow Through"), a resina empacotada foi lavada com 15 volumes de tampão de lavagem $\left(50 \mathrm{mM} \mathrm{NaH}_{2} \mathrm{PO}_{4}, 300 \mathrm{mM} \mathrm{NaCl}, 80 \mathrm{mM}\right.$ imidazol, $\mathrm{pH}$ 8,0), coletados a cada $1 \mathrm{~mL}$ e as proteínas ligadas a resina foram eluídas com solução de eluição contendo $\left(50 \mathrm{mM} \mathrm{NaH}_{2} \mathrm{PO}_{4}, 300 \mathrm{mM} \mathrm{NaCl}, \mathrm{pH} 8,0\right)$ e um gradiente de eluição de Imizadol, com concentrações variando entre 100-250mM imidazol, $\mathrm{pH}$ 8,0. As amostras coletadas foram aplicadas em SDS-PAGE e o gel corado com "Coomassie Blue” R250 para verificar o comportamento dessas frações. 


\subsection{Quantificação de Proteínas}

A quantificação de proteínas foi realizada pelo método de Bradford (Bradford, 1976), baseado na interação entre o corante Coomassie brilliant blue G-250 e proteínas que contém aminoácidos de cadeiais laterais básicas ou aromáticas. A curva padrão foi feita com soroalbumina bovina (BSA) na faixa de concentração de 2 a $20 \mu \mathrm{g} \cdot \mathrm{mL}^{-1}$. Para a leitura da absorbância no comprimento de onda de $595 \mathrm{~nm}$ foi utilizado espectrofotômetro (FEMTO 700S).

\subsection{Análise da estrutura de MIF recombinante e os mutantes em solução}

\subsubsection{Determinação da Massa Molecular}

A cromatografia por exclusão de tamanho, também chamada de cromatografia de filtração em gel separa proteínas de acordo com seu tamanho. Neste método as proteínas maiores são eluídas da coluna mais rapidamente que as proteínas menores. A matriz da coluna é composta por um polímero com ligações cruzadas, formando poros de diferentes tamanhos, retardando as proteínas menores, que penetram nesses poros e facilitando a migração das proteínas maiores que não penetram pelos poros, fazendo com que tenham um percurso mais rápido através da coluna. A técnica de filtração em Gel, assim como as técnicas eletroforéticas, pode fornecer dados para a determinação do peso molecular das proteínas em condições desnaturantes ou não. A determinação do peso molecular é realizada comparando-se o volume de eluição da proteína de interesse com os valores obtidos para vários padrões de calibração através do coeficiente de partição $\mathrm{K}_{\mathrm{Av}}$ (Nelson \& Cox, 2003). 
$\mathrm{O}$ Coeficiente de partição é dado pela equação $\mathrm{k}_{\mathrm{AV}}=\mathrm{V}_{\mathrm{e}}-\mathrm{V}_{\mathrm{o}} / \mathrm{V}_{\mathrm{t}}-\mathrm{V}_{\mathrm{o}}$ onde $\mathrm{V}_{\mathrm{e}}=$ Volume de Eluição, $V_{o}=$ volume de eluição do Blue Dextran (volume "void") e $V_{t}=$ Volume total da coluna. A curva padrão é obtida plotando-se os valores $\mathrm{k}_{\mathrm{AV}}$ versus o logaritmo dos pesos moleculares, e a partir desta curva pode-se determinar o peso molecular da proteína desconhecida em solução.

A cromatografia por filtração em gel foi realizada em um sistema de cromatografia líquida Shimadzu, utilizando a coluna S100 Sephacryl-HP 16/60 (GE lifesciences) equilibrada à temperatura ambiente com tampão 20mM TRIS, pH7.5, $50 \mathrm{mM} \mathrm{NaCl}$ e fluxo $0,5 \mathrm{~mL} \cdot \mathrm{min}^{-1}$. A seguir, a coluna foi padronizada usando marcadores moleculares de massas conhecidas: Aprotinina $(6,5 \mathrm{kDa})$, Citocromo $\mathrm{C}$ (12,4kDa), Anidrase Carbônica (29kDa), Albumina (66kDa) e Blue Dextran 2000kDa para medir o volume "void" da coluna. Os padrões foram eluídos separadamente. Para a caracterização da rLmMIF2 e os mutantes P2G, K34E, W66L, W108F e Delta (103113) utilizou-se as proteínas purificadas por cromatografia de afinidade Ni-NTA com a concentração $1 \mathrm{mg} \cdot \mathrm{mL}^{-1}$ em 20mM TRIS, pH7.5, 50mM NaCl.

\subsubsection{Dicroísmo Circular}

O dicroísmo circular é uma técnica extremamente sensível à assimetria quiral de moléculas em solução. É definido como a diferença de absorção entre a polarização circular da luz para a esquerda e para a direita. O sinal, que pode ser positivo ou negativo, dependendo da orientação das moléculas na amostra e da transição eletrônica que está sendo estudada, é verificado no comprimento de onda em que a amostra absorve fótons. O espectro de dicroísmo circular (CD) nas regiões do UV distante (190 - 250nm) é usado para avaliação da estrutura de proteínas, pois a estrutura secundária é 
conseqüência de ângulos de rotação livre das ligações da cadeia principal que resultam em orientações definidas de resíduos vizinhos, gerando sinais de CD específicos. Esses sinais são utilizados como fonte da análise comparativa das estruturas secundárias de diferentes proteínas. A ligação peptídica absorve na região UV (1800-2300Å). As formas regulares de arranjos atômicos interagem de modo particular com a radiação polarizada, fazendo, por exemplo, com que uma luz com polarização circular no sentido horário seja absorvida diferentemente de uma luz com polarização no sentido antihorário (Fasman, 1996).

O espectro de CD nas regiões do UV próximo $(250$ - 330nm) possui menor sensibilidade e é utilizado para avaliar a estrutura terciária das proteínas. Descreve a região aromática das moléculas, embora transições de ligações de dissulfeto contribuam para a intensidade de absorção. Através das análises de dicroísmo circular podemos saber se mudanças na temperatura, $\mathrm{pH}$ e a presença de outras moléculas e solventes são capazes de modificar a estrutura da proteína e se essas modificações alteram a atividade biológica da macromolécula (Fasman, 1996).

As análises de CD nas regiões do UV distante $(190$ - 250nm) foram feitas em espectropolarímetro JASCO-810, utilizando uma cubeta de quartzo de $0,1 \mathrm{~mm}$, com amostras da proteína nativa e das mutantes, numa concentração de $100 \mu \mathrm{g}$ por $200 \mu \mathrm{L}$ diluídos em tampão 20mM fosfato/citrato, pH 3,0, 4,0, 5,0, 6,0 e 7,0 e tampão 20mM Glicina/HCl pH2,0. Foram realizadas cinco leituras, gerando um espectro médio que foi corrigido posteriormente pela subtração do espectro do tampão sem proteína.

As análises de CD nas regiões do UV próximo $(250$ - 330nm) foram realizadas em espectropolarímetro JASCO-810, utilizando uma cubeta de quartzo 5,0mm, com amostras da proteína nativa e das mutantes, numa concentração de $0,5 \mathrm{mg} \cdot \mathrm{mL}^{-1}$ diluídos em tampão 20mM fosfato/citrato, $\mathrm{pH}$ 3,0, 4,0, 5,0, 6,0 e 7,0. 


\subsubsection{Espectrofluorescência da Emissão Intrínseca do Triptofano}

A caracterização do ambiente do triptofano e, consequentemente da proteína, pode ser feita através de estudos de fluorescência intrínseca do triptofano, que é uma técnica sensível a ligação de substratos às reações de associação com supressores de fluorescência e à desnaturação de proteínas (Lakowicz, 1983).

As medidas foram realizadas usando espectrofluorímetro SLM8100C, a $25^{\circ} \mathrm{C}$ e em cubeta de quartzo de caminho óptico de $1 \mathrm{~cm}$. A excitação foi em $295 \mathrm{~nm}$ e emissão de 300 a $470 \mathrm{~nm}$, abertura das fendas de excitação e emissão de $5 \mathrm{~nm}$ e voltagem da fotomultiplicadora de $700 \mathrm{~V}$. A concentração das proteínas utilizadas foi de $0,06 \mu \mathrm{g} . \mu \mathrm{L}^{-1}$ diluídas em tampão 20mM fosfato/citrato e 150mM de $\mathrm{NaCl}, \mathrm{pH}$ 7,0, 6,0, 5,0, 4,0 e 3,0 e tampão 20mM Glicina/HCl, pH2,0. Foram realizadas 3 leituras gerando um espectro médio, que foi corrigido posteriormente pela subtração do espectro do tampão sem proteína.

\subsection{Ensaio da Migração de Macrófagos}

O ensaio de migração foi realizado em microcâmera de quimiotaxia para estímulo celular através do protocolo modificado por Schleimer et al., (1989). No centro de uma lamínula de $13 \mathrm{~mm}$ foram colocados $20 \mu \mathrm{L}$ de meio de cultura contendo $7 \mathrm{X} 10^{4}$ células JM774 imortalizadas, que foram incubadas por 30 min em estufa a $5 \% \mathrm{CO}_{2} \mathrm{e}$ $37^{\circ} \mathrm{C}$ para permitir a sua adesão e espalhamento no substrato. Em seguida, foram adicionados $250 \mu \mathrm{L}$ de meio de cultura e, então, as células foram cultivadas overnight em estufa com $5 \% \mathrm{CO}_{2}$ à $37^{\circ} \mathrm{C}$. No dia seguinte, as lamínulas foram "riscadas" com uma ponteira estéril (capacidade $200 \mu \mathrm{L}$ ) criando, no centro da lamínula, uma faixa 
central sem células. Os poços foram lavados 2x com PBS para retirar as células que foram removidas da lamínula pela ponteira. Em seguida, as células foram pré-incubadas por 3 h com meio de cultura contendo ou não 100 ng.mL ${ }^{-1}$ de $L m M I F 2$ nativa e MIF mutante. Após esse período, foram adicionados aos poços 100 ng.mL ${ }^{-1}$ de LPS para indução de migração para dentro da faixa central (controle positivo). O controle negativo foi cultivado apenas em meio de cultura. Após 8 horas de cultivo as células foram lavadas em PBS e fixadas com paraformaldeído $2 \%$ em PBS, por 15 min. A seguir, as células foram lavadas 2 vezes em PBS e coradas por 20 min com $0,48 \mu \mathrm{M}$ de DAPI (Invitrogen - Molecular Probes). As lamínulas foram então, lavadas em PBS, passadas rapidamente em água destilada e montadas com Fluormount G. A quantificação das células em migração foi feita com auxílio do microscópio de fluorescência Olympus BX50F4 (Olympus Optical CO. Ltda). O resultado foi analisado como porcentagem de células que migram devido à presença de LPS; e na presença e ausência das proteínas. 
Elise Marques Freire Cunha

Resultados e Discussão

4. Resultados e Discussãa 


\section{Resultados e Discussão}

A seleção das posições mutadas na estrutura do MIF foi baseada no objetivo de se estudar o papel da atividade enzimática e do estado de oligomerização na atividade biológica de interação com macrófagos. A primeira mutação do sítio ativo escolhida em estudos com MIFs foi a Prolina 2, que é essencial para a tautomerização (Swope \& Lolis, 1999). Nos MIFs de mamíferos e de nematóides foi observado que a substituição da Prolina por uma Glicina resultou em uma redução significativa na atividade catalítica e na atividade de liberação de citocinas pelo macrófago (Swope \& Lolis, 1999; Zang et al., 2002). O mutante K34E foi proposto já que a lisina na posição 34 foi descrita como importante para a atividade de tautomerização por estabilizar o substrato no sítio ativo do MIF de mamíferos (Lubetsky et al., 1999; Taylor, et al., 1999). Além disso, a sequência 34-36 em rLmMIF2 forma uma alça que mantém o motivo GKP conservado em relação a MIF de mamíferos (Richardson et al., 2009).

A mutação sítio-dirigida de triptofanos e resíduos de regiões da interface oligomérica, aliada a estudos espectroscópicos em solução podem contribuir para uma resposta a respeito da estrutura quaternária da MIF2 de L. major em solução e se essa estrutura é aquela que interage com o receptor de membrana dos macrófagos. Os mutantes propostos foram W66L e W108F, usados principalmente em estudos de emissão fluorescência intrínseca do triptofano (IFTE) e de dicroísmo circular para avaliação das estruturas secundária, terciária e quaternária. A deleção dos resíduos $\Delta 104-113$ possibilitou avaliar o papel dessa cauda na oligomerização e se, a mesma, é necessária para a atividade biológica. 


\subsection{Mutagênese sítio-dirigida por PCR}

A Figura 06 mostra um gel de agarose $1 \%$ referente a primeira etapa da mutagênese sítio-dirigida, em que utilizou-se o oligonucleotídeo iniciador EXT1 e os primers mutagênicos (5' MUT-MIF), descritos na Tabela 01. O tamanho dos fragmentos amplificados foi de acordo com o esperado, conforme a posição de anelamento do oligonucleotídeo mutante na fita molde do vetor pET21MIF. Os tamanhos obtidos foram: W108F (412pb), K34E (187pb), W66L (283pb), P2G (464pb) e $\Delta(104-113)$ (396pb).

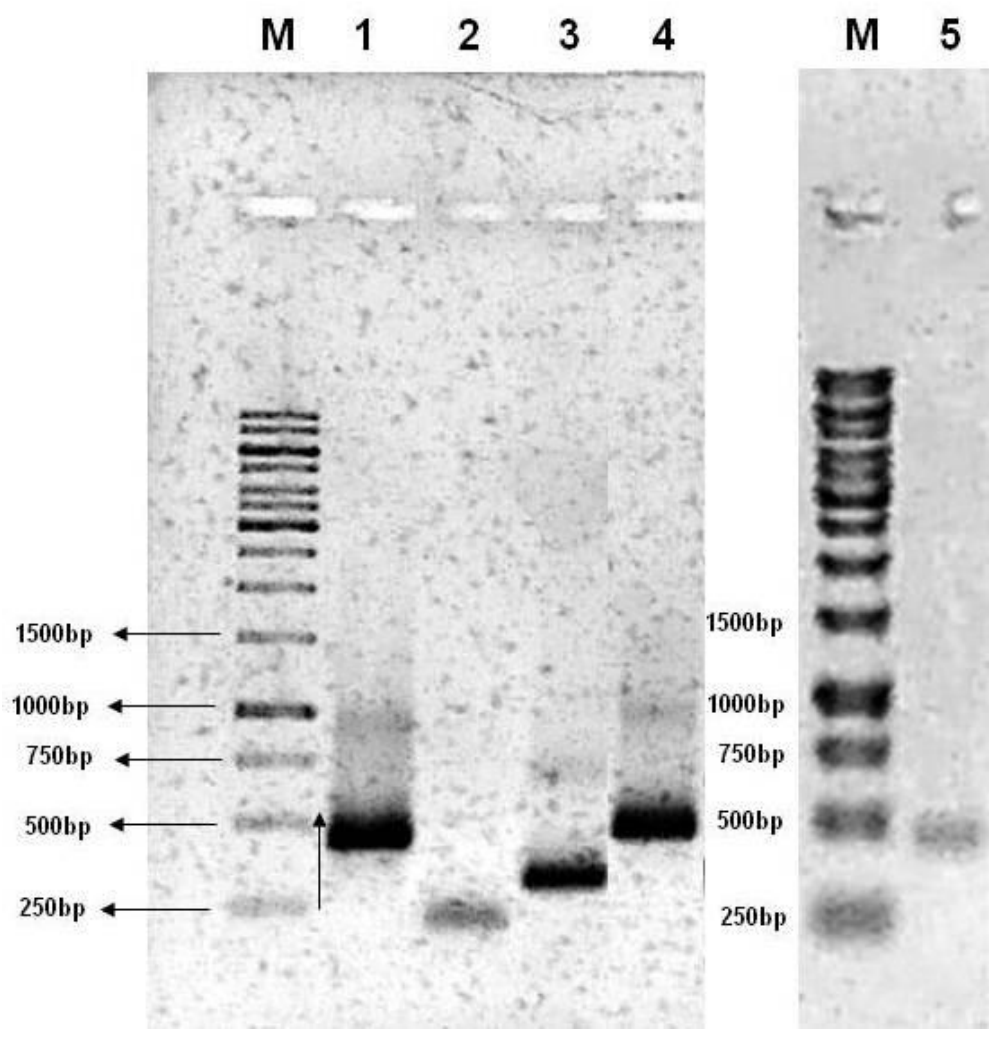

Figura 06: Resultado da etapa da reação de mutagênese sítio-dirigida. Gel de agarose $1 \%$ referente a reação 1 de mutagênese sítio-dirigida. M - Marcador de peso molecular $1 K b$ Plus (Invitrogen). De 1 a 5 têm-se respectivamente os mutantes $\mathrm{W} 108 \mathrm{~F}, \mathrm{~K} 34 \mathrm{E}, \mathrm{W} 66 \mathrm{~L}, \mathrm{P} 2 \mathrm{G}$ e o mutante $\Delta(104-113)$.

A Figura 07 mostra um gel de agarose $1 \%$ contendo fragmentos de $634 \mathrm{pb}$, obtido após as reações de extensão (reação 2) e amplificação (reação 3) da sequência codificadora completa, utilizando os oligonucleotídeos EXT2, T7 terminator e T7 promoter. O fragmento 
apresentou tamanho esperado, equivalente ao tamanho da sequência codificadora somado ao tamanho das regiões flanqueadoras do vetor, entre as duas posições de anelamento dos primers T7. O fragmento de tamanho esperado foi cortado do gel e, em seguida, foi submetido à purificação e digestão.

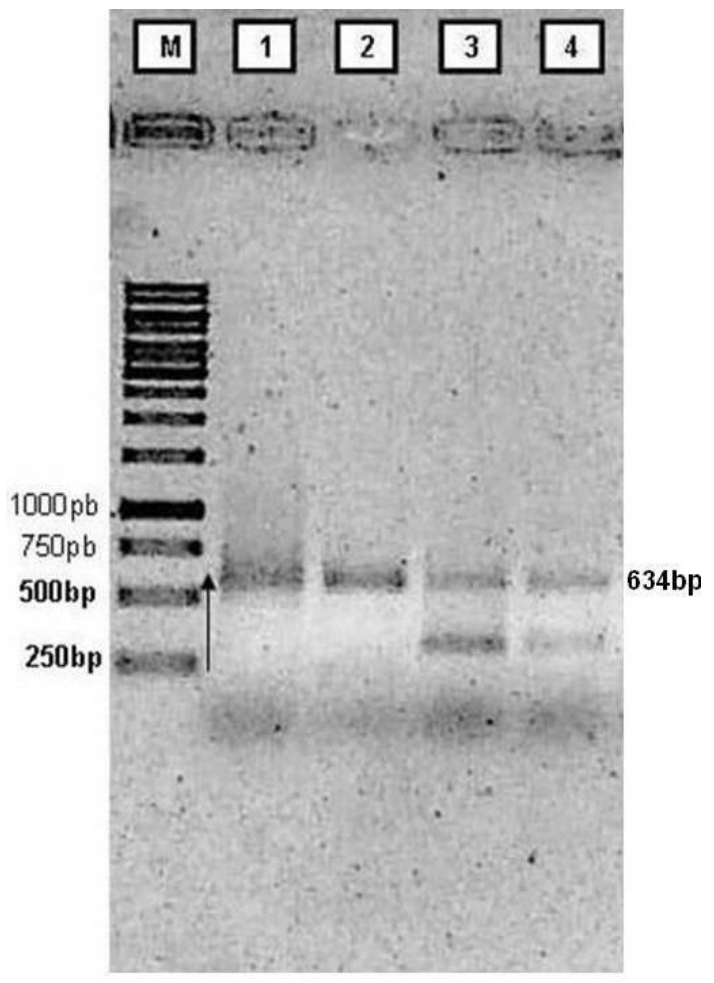

Figura 07: Gel de agarose $1 \%$ referente as reações 2 e 3 da mutagênese sítio-dirigida. M-Marcador de peso molecular $1 \mathrm{~Kb}$ Plus (Invitrogen); (1) Fragmento referente ao mutante K34E; (2)W66L, (3) W108F e (4) $\mathrm{P} 2 \mathrm{G}$ com fragmentos de aproximadamente $634 \mathrm{pb}$.

\subsection{Digestão dos fragmentos com enzimas NdeI e HindIII}

Após a purificação dos fragmentos das reações de PCR mutagênico, eles foram submetidos à digestão com enzimas de restrição NdeI e HindIII, resultando em fragmentos de aproximadamente $350 \mathrm{pb}$ referente às sequências codificadoras mutadas como mostrado na Figura 08. 
Figura 08: Digestão dos fragmentos da reação 3. Gel de agarose $1 \%$ referente à digestão com enzimas de restrição NdeI e HindIII liberando o fragmento de $\sim 350 \mathrm{pb}$. Em $\mathrm{M}$ temos o marcador de peso molecular de 100 pb (Invitrogen); (1) Mutante W108F; (2) K34E; (3) W66L; (4) P2G.

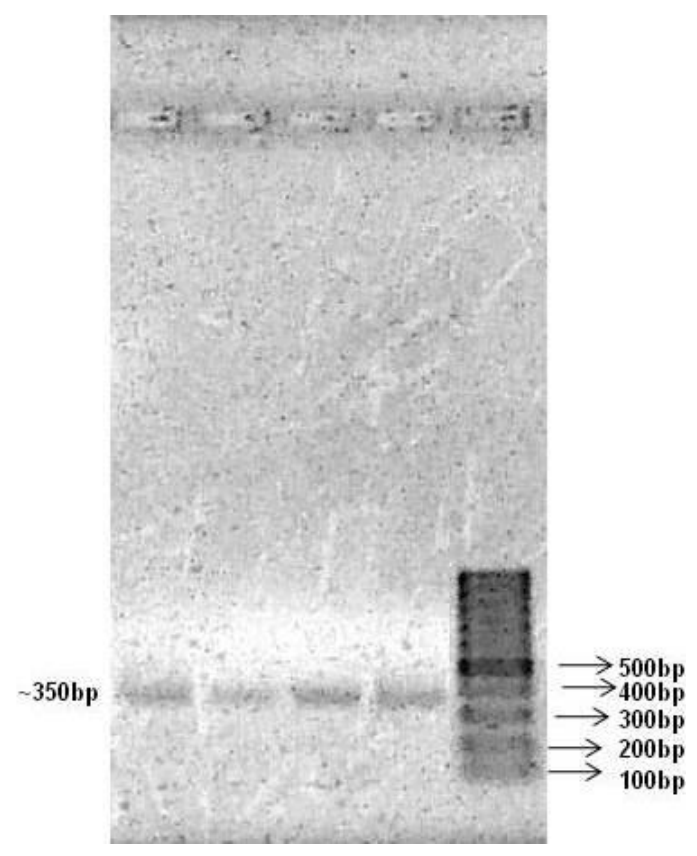

\subsection{Clonagem dos fragmentos mutantes no vetor de expressão pET21b}

Os fragmentos, obtidos da digestão com as enzimas NdeI/HindIII, foram ligados conforme o protocolo da enzima T4 DNA ligase (Invitrogen). A solução de ligação, contendo pET21b com fragmento foi usada para transformação, por choque térmico, da linhagem DH5á competente de E. coli. As colônias que continham o pET21MIF-mutante foram identificadas por reação de PCR em colônia, usando os oligonucleotídeos iniciadores T7. A ligação desse fragmento no vetor foi confirmada após a extração do DNA plasmidial das bactérias, observado em gel de agarose 1\% do PCR de colônias (Figura 09), indicando as colônias contendo o gene inserido mais as regiões flanqueadoras, somando aproximadamente 650pb.

Na Figura 10 observa-se a diferença de tamanho $(\mathrm{pb})$ entre o vetor $\mathrm{pET} 21 \mathrm{~b}$ vazio e os vetores contendo os insertos de interesse, obtidos após a extração do DNA plasmidial das colônias positivas. 
Figura 09: Gel de Agarose 1\% do PCR de Colônia Gel de Agarose $0,8 \% \mathrm{M}$ Marcador de peso molecular $1 \mathrm{~Kb}$ Plus e 1 a 5 amplificações do clone W108F de $\sim 650 \mathrm{pb}$ mostrando que houve correta ligação do inserto no vetor.

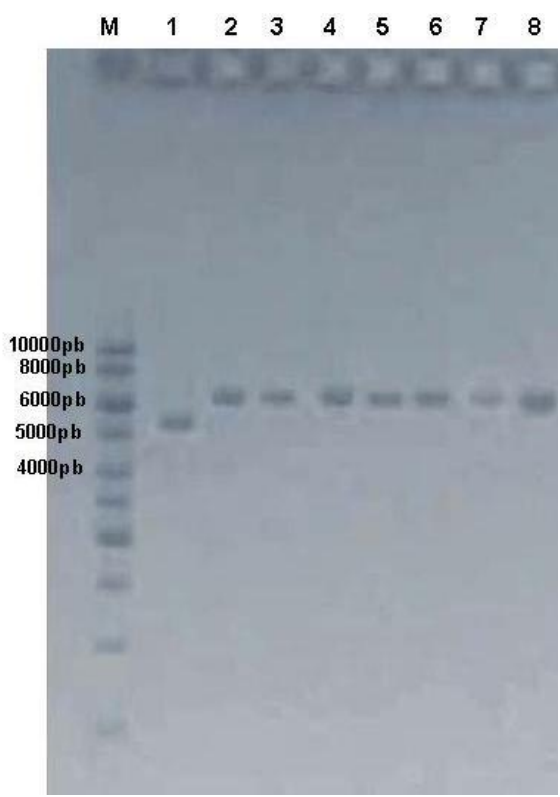

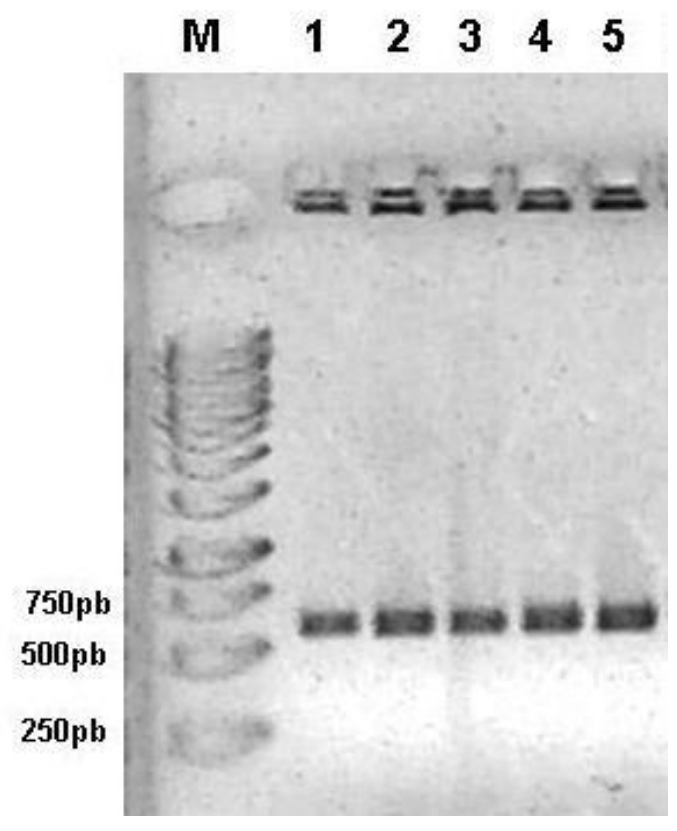

Figura 10: Gel de Agarose 1\% da extração de plasmídeo de bactérias transformadas com pET21MIFMUT. Na canaleta 1) Marcador $1 \mathrm{~Kb}$ Plus; 2)pET21b vazio; 3)pET21brLmMIF2; 4)pET21bMUT W108F; 5)pET21bMUT - K34E; 6)pET21bMUT - W66L; 7)pET21bMUT - P2G; 8)pET21bMUT - $\Delta(104-113)$.

\subsection{Sequenciamento dos mutantes de MIF}

As mutações foram comprovadas por reação de sequenciamento automático de nucleotídeos. Os eletroferogramas obtidos mostram as sequiências de DNA das regiões codificadoras dos mutantes, comparados com as sequiências das regiões correspondentes da forma selvagem. A Figura 11 mostra os eletroferogramas obtidos: em 1A tem-se o códon CCG que codifica o aminoácido Prolina e em 1B observa-se o códon GGC, que codifica Gly 
na mesma posição, o que indica que ocorreu uma mutação na posição 2. Em 2A tem-se o códon AAG que codifica o aminoácido Lys, e em 2B observa-se a mudança desde códon para GAG, que codifica o aminoácido Glu, mostrando que ocorreu uma mutação não conservativa na posição 34 (K34E). Além desse mutante observa-se a correta mutação do aminoácido Trp para Leu na posição 66 (W66L) em 3A e Trp para Phe na posição 108 (W108F) em 4A.

Na Figura 12 (A) observa-se o códon CAC que codifica o aminoácido His, em seguida, observa-se os códons TGC GGC TGG AAC GGC ACT AAC e TTT, que correspondem respectivamente aos aminoácidos Cys, Gly, Trp, Ans, Gly, Thr, Asn e Phe. Em (B) observa-se o códon CAC que codifica o aminoácido His e, em seguida, o sítio de restrição da enzima HindIII AAG CTT, o que confirma a deleção da sequência de aminoácidos de 104 a 113 na região $C$ terminal da proteína.

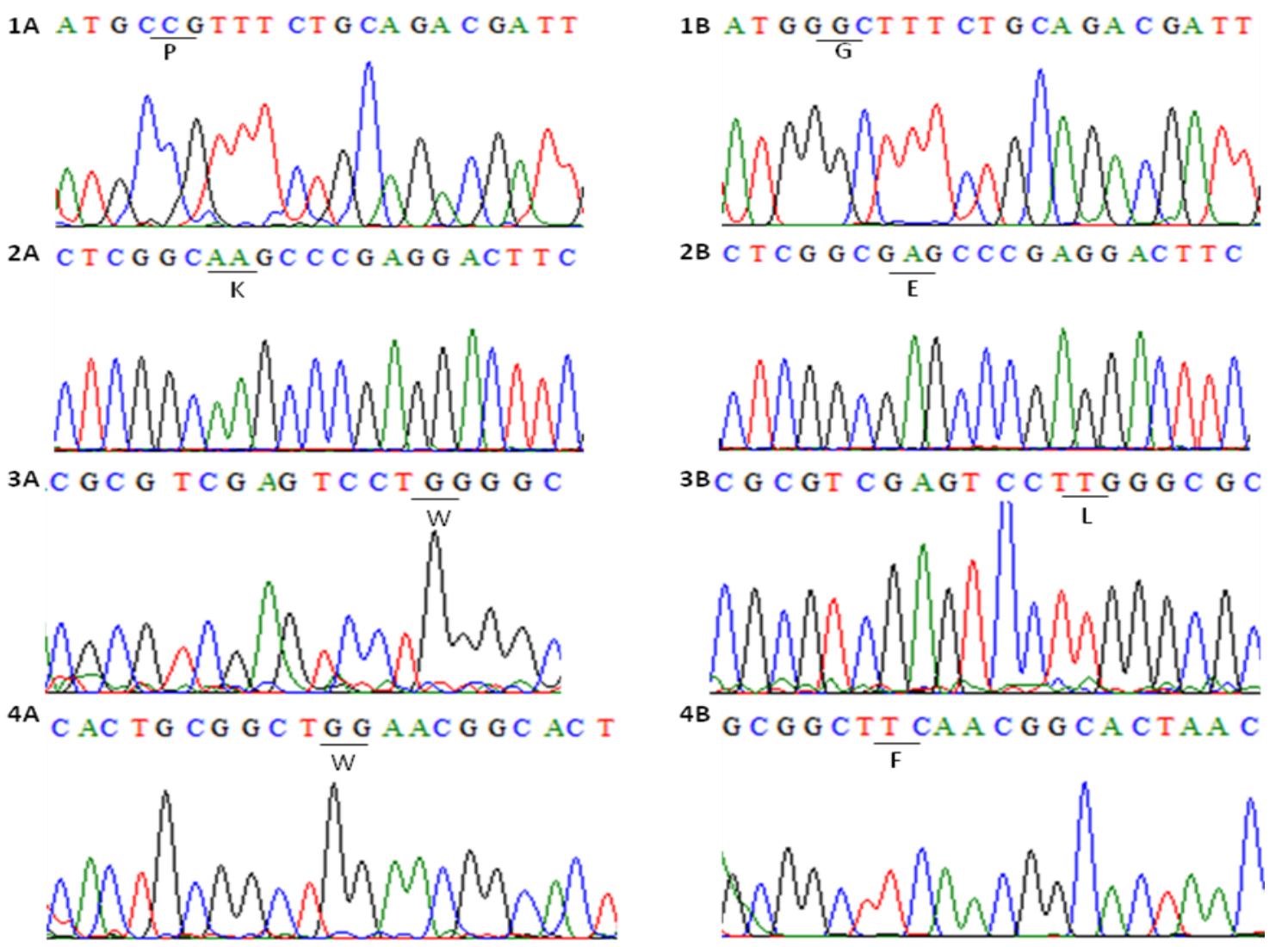

Figura 11: Eletroferogramas das mutações. Em (1A) tem-se o códon CCG que codifica o aminoácido Pro, e em (1B) observa-se a mutação para o códon GGC que codifica o aminoácido Gly. Em (2A) e (2B) K34E; (3A) e (3B) W66L e (4A) e(4B) W108F. 


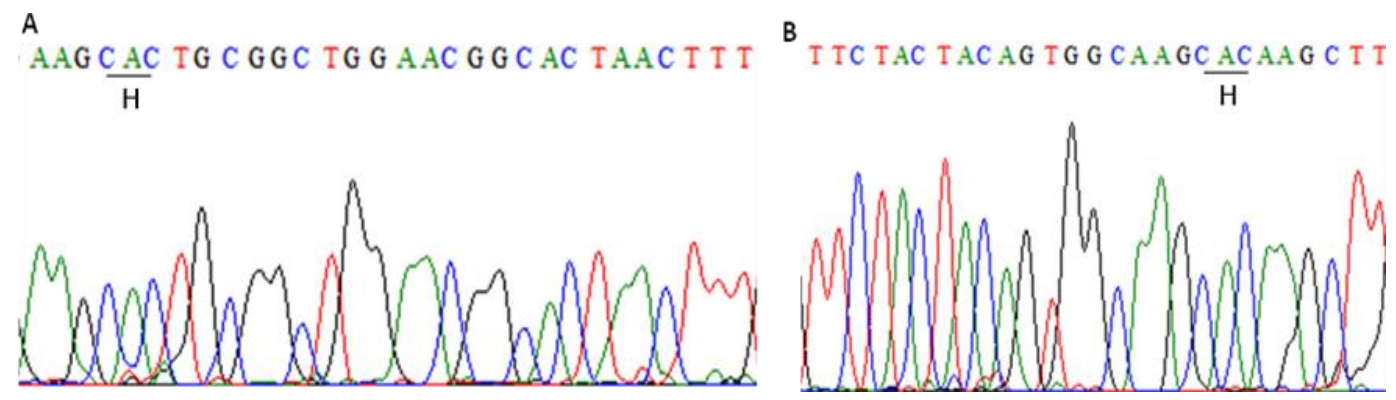

Figura 12: Eletroferograma da mutação $\Delta$ (104-113). (A) MIF de Leishmania major selvagem e (B) deleção dos aminoácidos $\Delta(104-113)$.

\subsection{Expressão em linhagem BL21[DE3]pLysS de E. coli e purificação das proteínas recombinante e mutantes}

A linhagem BL21[DE3]pLysS foi transformada com a construção dos clones pET21bMIFMUT e as colônias de bactéria transformadas foram inoculadas em meio de cultura HDM na presença de antibióticos. A Figura 13 mostra que as proteínas foram eficientemente expressas após 06 horas de indução apresentando uma banda de aproximadamente $14,5 \mathrm{kDa}$ referente a proteína recombinante mutada em fusão com a cauda de histidina. Após a expressão das proteínas, as bactérias foram lisadas e o extrato bruto foi centrifugado para obtenção dos extratos solúvel (S) e insolúvel (I) para o teste de solubilidade, mostrado na Figura 14 observa-se uma banda de aproximadamente $14,5 \mathrm{kDa}$ no extrato do sobrenadante da lise, mostrando que as proteínas foram expressas no citoplasma da bactéria de forma solúvel como observado para a MIF selvagem de L. major e ortólogos em outros parasitas como Brugia, Ancylostoma, Trichinella e Plasmodium (Tan et al., 2001; Zang et al., 2002; Cho et al., 2007; Cordery et al., 2007). 


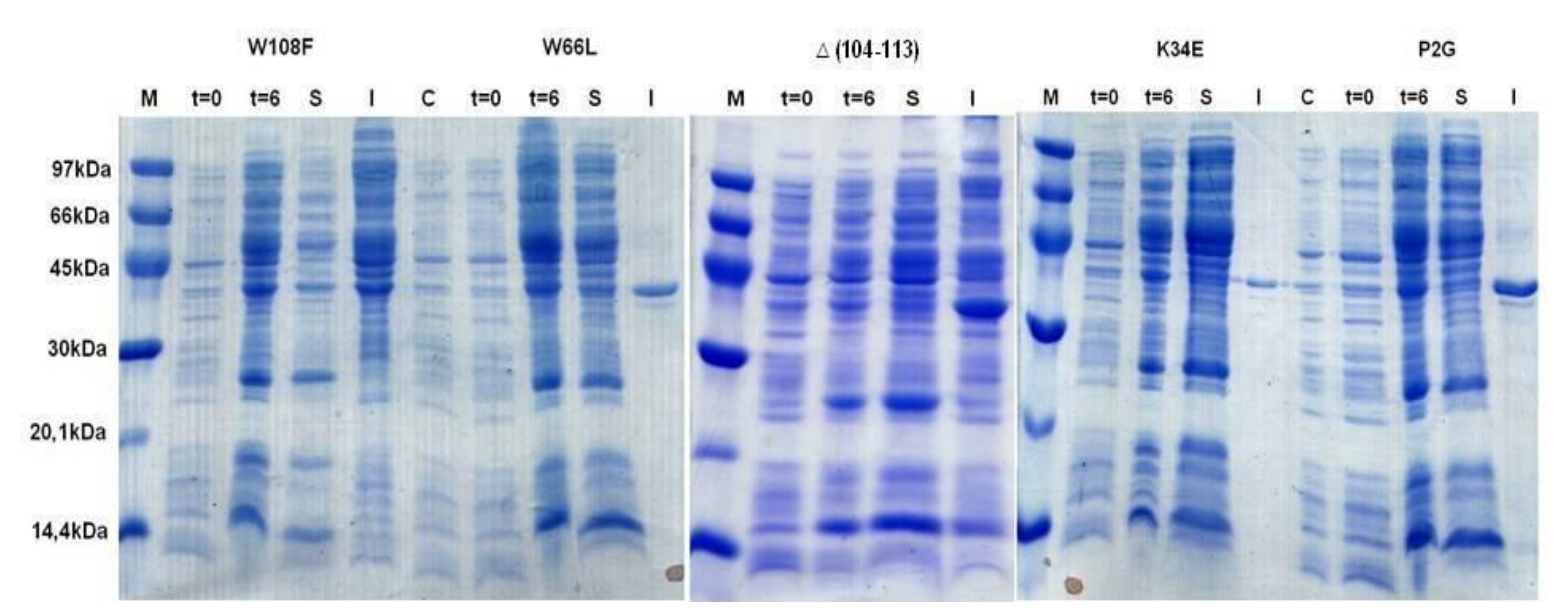

Figura 13: Gel SDS-PAGE de expressão e solubilidade das proteínas mutantes. M=Marcador de Peso Molecular - LWM (GE lifesciences); C= Controle de Expressão com pET21b sem a inserção do gene; T=0 (tempo de indução de 0horas) T=6 (tempo de indução de 6horas); S= Extrato Solúvel e I= Extrato Insolúvel.

O extrato solúvel da lise de BL21[DE3]pLysS foi incubado com resina de Ni-NTA e a proteína de interesse foi eluída em tampão de eluição de 200mM de Imidazol, porém boa parte da proteína de interesse era eluída juntamente com outras proteínas de E. coli, e a presença desses contaminantes impedia a execução dos experimentos seguintes. Sendo assim, foi estabelecido um protocolo de purificação dessas proteínas utilizando tampões de eluição contendo gradiente de imizadol nas concentrações: 100, 150, 200 e 250mM em 4 frações de $1 \mathrm{~mL}$ para cada concentração.

A Figura 14 mostra uma banda de 14,5kDa no gel de SDS-PAGE com o gradiente de eluição contendo 150, 200 e 250mM de Imidazol da proteína mutante W108F purificada em cromatografia de afinidade Ni-NTA. O mesmo comportamento foi observado para a MIF recombinante e as outras proteínas mutantes. As proteínas eluídas foram quantificadas pelo método de Bradford (1976) e nas purificações com maior rendimento para 1L de cultura foram obtidas 24mg para rLmMIF2 e os mutantes W108F e W66L, 10mg para o mutante K34E e 2mg para o $\Delta(104-113)$. 


\section{W108F}

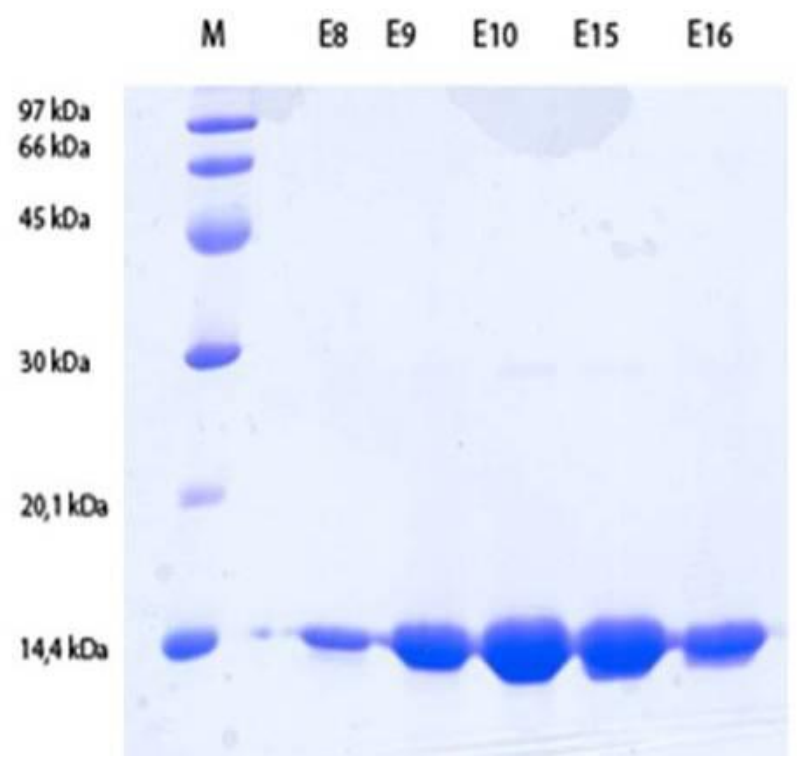

Figura 14: Gel de Purificação SDS-PAGE $15 \%$ com gradiente de eluição do mutante W108F. (LW) Marcador de Peso Molecular. (E8) Eluição com 150mM de Imidazol (E9 E10) $200 \mathrm{mM}$ de Imidazol (E15 - E16) $250 \mathrm{mM}$ de Imidazol.

\subsection{Determinação da Massa Molecular por Cromatografia de Filtração em Gel}

Os perfis de filtração da $r L m M I F 2$ e os mutantes podem ser observados na Figura 15. As proteínas mostram picos simétricos, variando entre 58,9 e 61,45mL. Através da análise dos padrões de massa molecular foi possível obter uma equação da reta e calcular a massa molecular das proteínas, determinando assim seu estado de oligomerização (Figura 16). De acordo com os resultados obtidos, as massas moleculares calculadas de $33 \mathrm{kDa}$ são compatíveis com uma forma dimérica composta de subunidades de aproximadamente 14,5kDa. A diferença observada, para os $29 \mathrm{kDa}$ teóricos, pode ser conseqüente de uma forma dimérica não totalmente globular e compactada, que poderia sair pouco mais tarde que uma forma globular esperada de $29 \mathrm{kDa}$.

Apesar de MIFs de diferentes organismos terem sido resolvidos cristalograficamente e todas as formas observadas foram monômeros ou trímeros, algumas dessas proteínas, foram observadas como dímeros em solução (Tan et al., 2001). A MIF2 recombinante de L. major e os mutantes P2G, K34E, W66L, W108F e $\Delta(104-113$ ), apresentaram-se como dímeros em 
solução. Esses resultados possibilitam inferir que talvez seja a forma dimérica que atue no receptor de macrófagos e não a trimérica descrita na literatura.

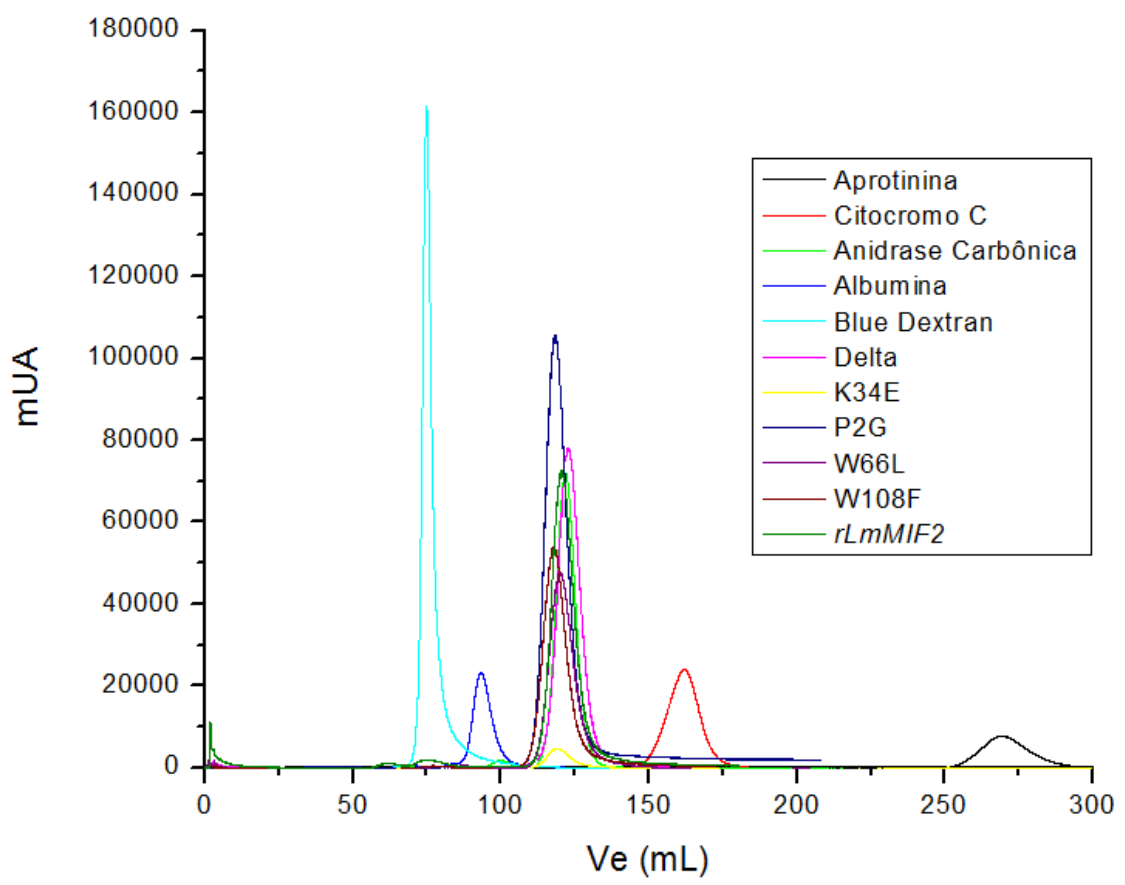

Figura 15: Perfil cromatográfico da $r L m M I F 2$, das proteínas mutantes e proteínas padrões obtidos por cromatografia de filtração em gel. A coluna foi equilibrada com $20 \mathrm{mmol} . \mathrm{L}^{-1}$ TRIS, $50 \mathrm{mmol} . \mathrm{L}^{-1} \mathrm{NaCl}, \mathrm{pH} 7,5 \mathrm{e}$ fluxo de $0,5 \mathrm{~mL} \cdot \mathrm{min}^{-1}$. O volume de injeção de $1 \mathrm{~mL}$ de cada padrão e da proteína $\left(1 \mathrm{mg} . \mathrm{mL}^{-1}\right)$ foram aplicados isoladamente.

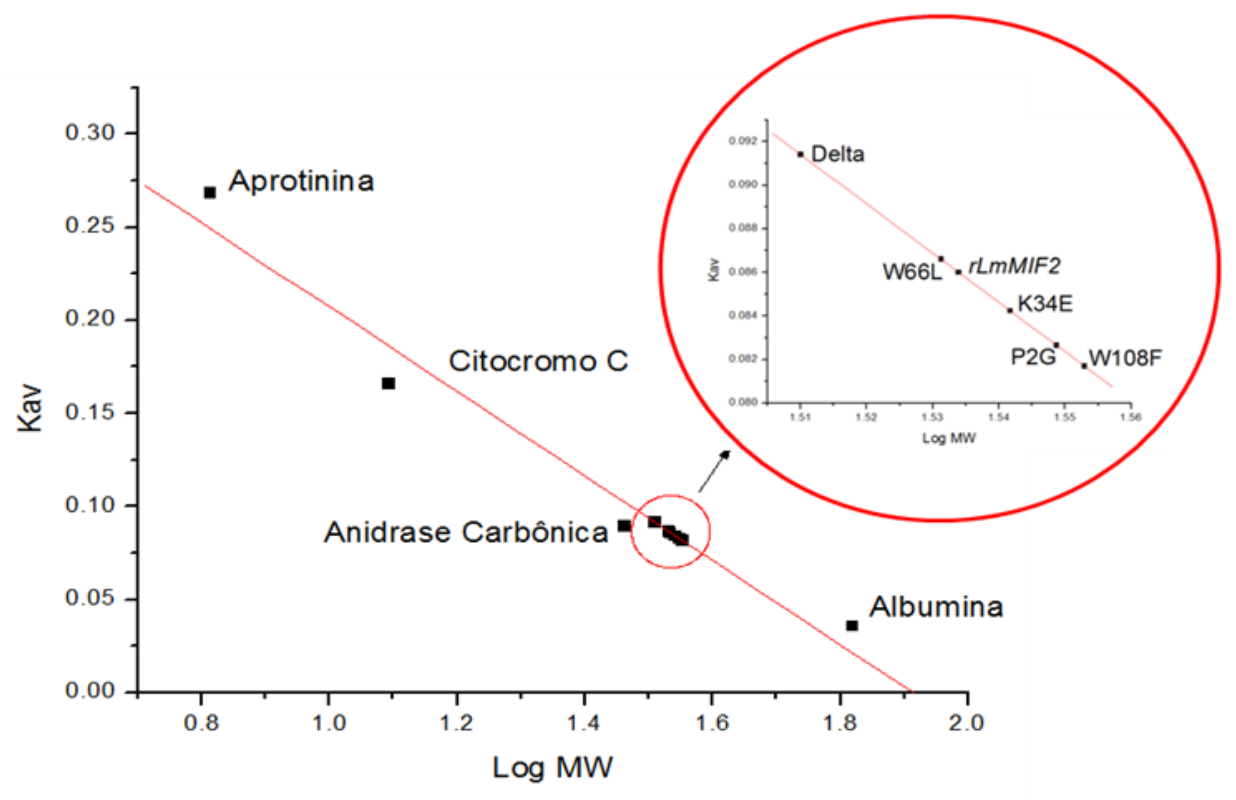

Figura 16: Perfil de correlação - Coeficiente de partição $K_{\mathrm{Av}}$ versus o logaritmo da massa molecular dos padrões aplicados na coluna Sephacryl ${ }^{\mathrm{TM}} \mathrm{S}-\mathbf{1 0 0}$. A equação da reta relaciona o logaritmo da massa molecular em $\mathrm{kDa}(\mathrm{MW})$ com o coeficiente de partição $\left(\mathrm{K}_{\mathrm{AV}}\right)$. O coeficiente de partição é calculado por meio da equação $\mathrm{K}_{\mathrm{AV}}=\mathrm{V}_{\mathrm{e}}-\mathrm{V}_{\mathrm{o}} / \mathrm{V}_{\mathrm{T}}-\mathrm{V}_{\mathrm{o}}$ onde $\mathrm{V}_{\mathrm{e}}=$ Volume de eluição, $\mathrm{V}_{\mathrm{o}}=$ Volume de eluição do Blue Dextran e $\mathrm{V}_{\mathrm{T}}=$ Volume total da coluna. 


\subsection{Avaliação Estrutural por Dicroísmo Circular}

Medidas de CD na região UV distante podem dar estimativas quantitativas de estrutura secundária que pode ser comparada com os dados de cristalografia de raios X ou ressonância magnética nuclear (Kelly et al., 2005). Espectros de CD nas diferentes regiões espectrais são de valor inestimável para avaliar as relações estruturais entre proteínas nativas, recombinantes e mutantes. Além disso, a análise de CD pode ser usada para confirmar a integridade dos domínios proteínas multi-domínio recombinantes e, ainda, ser um requisito essencial a estudos estruturais a serem realizados como, por exemplo, cristalografia de raios-X (Missiakas et al., 1990; Munro et al., 1994)

Após a etapa de purificação e dosagem das proteínas rLmMIF2 e mutantes foram realizados experimentos de dicroísmo circular (CD) na região do UV distante em pH 7,0 para avaliar a integridade da estrutura secundária dessas proteínas recombinantes. Pode-se observar na Figura 17, para o rLmMIF2, duas bandas mínimas, uma em 222nm e outra entre 208 e 210nm e uma banda máxima em 196nm. O espectro indica uma estrutura secundária do tipo $\alpha / \beta$ com predominância de $\beta$-folha, com uma contribuição menor de $\alpha$-hélice. Resultados semelhantes foram descritos sobre a estrutura secundária de MIFs selvagens e recombinantes de outros organismos (Bernhagen et al., 1994; Calandra et al., 1995; Swope e Lolis, 1999; Tan et al., 2001; Kudrin et al., 2006). O mutante P2G apresentou estrutura secundária similar a do MIF, com elipticidade negativa em $222 \mathrm{~nm}$ e $208 \mathrm{~nm}$, mostrando que esta mutação não alterou a predominância de estrutura em $B$ da cadeia polipeptídica, mas a diferença nas bandas (mais negativas) para o P2G indicam que as posições das ligações peptídicas não são idênticas à da LmMIF2 recombinante. Os mutantes K34E, W66L e W108F apresentaram espectros com elipticidades mais negativas em relação ao rLmMIF2 selvagem, mas esses mutantes apresentaram um aumento na elipticidade em 208nm, indicando uma contribuição maior em 
$\alpha$-hélice que na recombinante, diminuindo a predominância das estruturas $\beta$ em relação às $\alpha$ hélices.

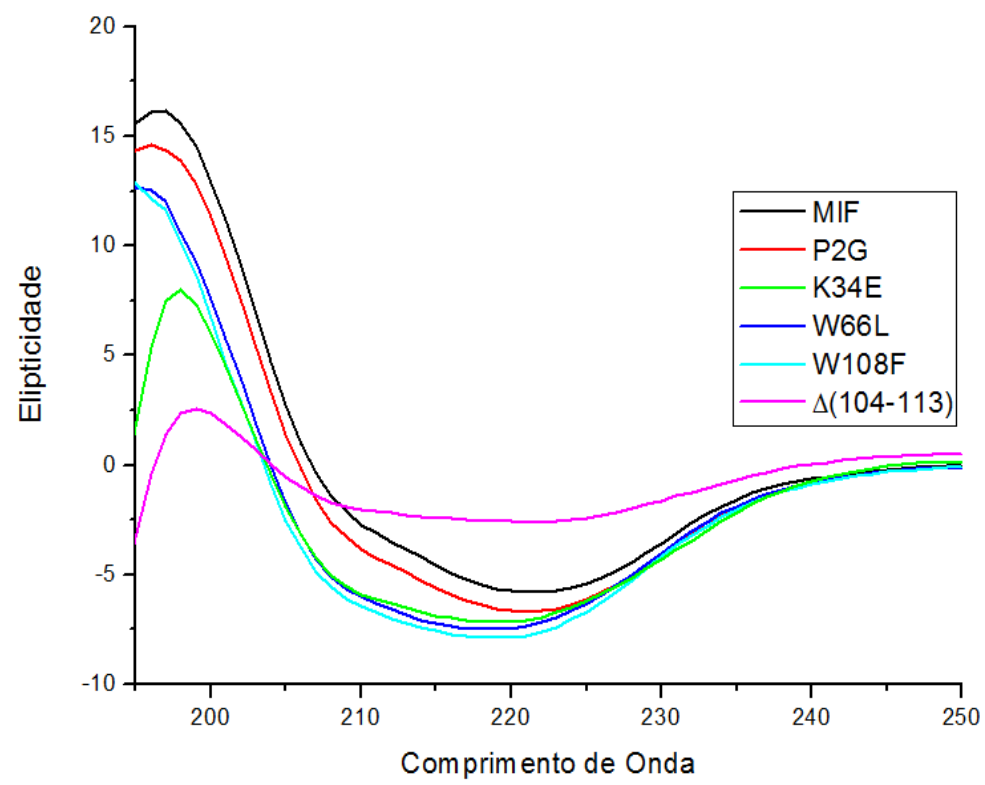

Figura 17: Espectro de Dicroísmo Circular no UV distante em pH 7.0 O gráfico ilustra os espectros de CD de MIF recombinante juntamente com os mutantes após expressão e purificação.

A cauda C terminal de MIFs, em particular os resíduos 104 a 113, é altamente conservada (>95\%) entre as diferentes espécies, sugerindo que essa região possa exercer um papel importante na estrutura e função da proteína (Sun et al., 1996). O mutante $\Delta(104-113)$ apresentou bandas mais próximas à elipticidade 0 , indicando uma perda parcial de estrutura secundária, confirmando a importância dessa região para a estrutura da proteína. Essa proteína mutante apresentou diferentes perfis de estrutura secundária em relação aos lotes de proteínas purificadas, variando desde o perfil com estrutura parcial (como mostrado na figura) até perfis mais próximos a elipticidade 0, indicando uma proteína totalmente desnaturada. Essa estrutura desorganizada expressa pela bactéria pode ser um dos motivos para o baixo rendimento de purificação apresentado por esse mutante. Ainda, a presença da cauda de histidina (His-tag) na porção C-terminal da proteína recombinante pode interferir no enovelamento dessa proteína. Estudos com a MIF humana, deletada em 5 ou 10 aminoácidos e purificada sem cauda de His-tag, mostraram que os mutantes mantiveram um perfil de espectro similar ao da 
recombinante, porém um aumento na elipticidade negativa indicou mais conformação “random coil” e a diminuição de conformação em ß-folha nas proteínas (Mischke, 1998).

Os espectros na região mais próxima da faixa de comprimento de onda visível, de 250330nm, denominados CD UV próximo são resultados da presença de aminoádcos aromáticos na proteína. Nas proteínas, cada um dos aminoácidos tende a ter um perfil característico de elipticidade em diferentes comprimentos de onda. O Triptofano (Trp) mostra uma grande banda em $290 \mathrm{~nm}$, com um pequeno ombro entre 290 e $305 \mathrm{~nm}$; tirosina (Tyr) apresenta um pico entre 275 e $282 \mathrm{~nm}$, com um ombro em comprimentos de onda maiores, muitas vezes cobertas por bandas do Trp. Fenilalanina (Phe) mostra bandas mais fracas, mas mais nítidas com estrutura fina entre 255 e $270 \mathrm{~nm}$ (Kelly et al., 1997). O espectro de uma proteína obtido através da análise de CD UV próximo fornece um perfil valioso para análise da estrutura terciária de proteínas que pode ser usado para comparar, por exemplo, tipo selvagem, recombimante e formas mutantes de proteínas (Kelly et al., 2005). Além disso, essa análise pode fornecer evidências importantes para detectar a existência do estado de glóbulo fundido em proteínas, que apresentam, entre outras características, um sinal mais fraco, refletindo a alta mobilidade das cadeias laterais aromáticas (Ptitsyn, 1995; Price et al., 2005).

A Figura 18 mostra que as mutações pontuais das proteínas recombinantes de MIF da L. major mudaram os espectros de dicroísmo, diminuindo a elipticidade indicando alteração na disposição das cadeias laterais dos aminoácidos. Esses resultados mostram uma alteração na estrutura terciária do mutante $\mathrm{P} 2 \mathrm{G}$ e apenas sugerem alterações nos mutantes de triptofano, pois neste caso deve-se considerar que a própria mutação poderia alterar o perfil do espectro dessas proteínas. 


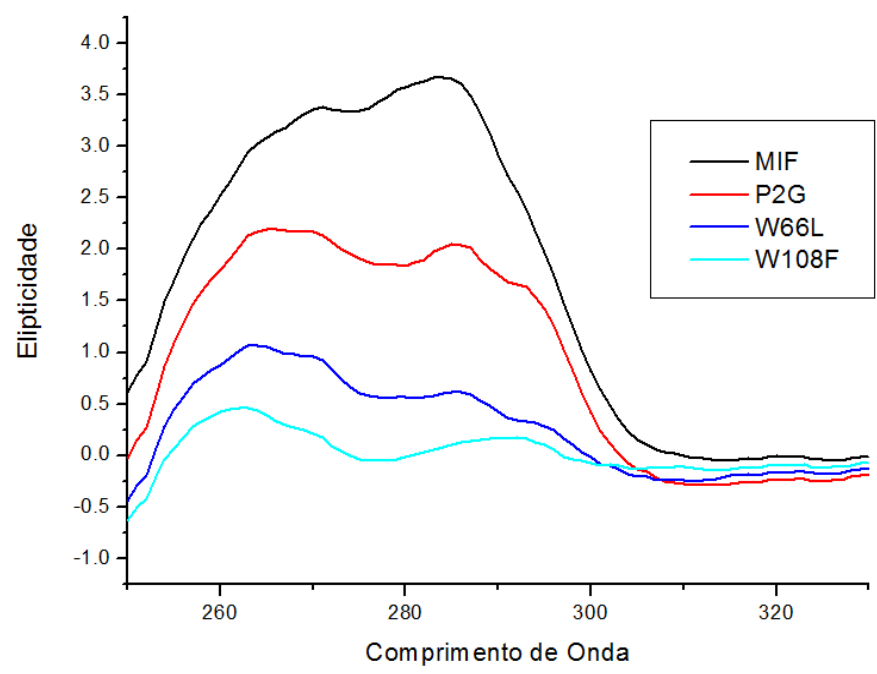

Figura 18: Análise por Dicroísmo Circular UV-próximo da $r$ LmMIF2 e os mutantes P2G, W66L e W108F em pH 7. As medidas foram realizadas a $25^{\circ} \mathrm{C}$ com $0,5 \mathrm{mg}$ de proteína em $1 \mathrm{~mL}$ de tampão $20 \mathrm{mM}$ fosfato/citrato.

\subsection{Análise espectroscópica do efeito do pH na estrutura do $r$ LmMIF2 e dos mutantes}

\subsubsection{Dicroísmo Circular}

As alterações na conformação de uma proteína, conseqüentes de mudanças de microambiente, podem ser essenciais para o mecanismo de ação e regulação da sua atividade biológica. Análises de dicroísmo circular permitem uma conveniente maneira de detectar tais mudanças que podem ser examinadas em diferentes regiões do espectro (Boxer et al., 2004). Uma das maneiras de se estudar essas mudanças de conformação da proteína é utilizar variação do $\mathrm{pH}$ que, possivelmente, pode estar associada à uma desnaturação em pHs muito ácidos. Esse tipo de análise se torna muito importante especialmente para proteínas que podem freqüentar ambientes celulares com diferentes pHs. No caso da MIF, que foi descrita como secretada em organismos (Calandra \& Roger, 2003) ela poderia, em Leishmania, estar atuando em pHs fisiológicos ou, se secretada no fagolisossomo em um $\mathrm{pH}$ ácido. Assim, o uso de técnicas espectroscópicas como o dicroísmo circular e fluorescência intrínseca do triptofano podem permitir um acompanhamento de mudanças conformacionais na variação do 
microambiente e, ainda, com o uso de proteínas mutantes, pode ser avaliado o papel de resíduos de aminoácidos durante essas mudanças estruturais.

Para monitorar a estrutura secundária da MIF recombinante de Leishmania major e das proteínas mutadas foram realizados ensaios de CD UV distante em diferentes pHs. A Figura 19 mostra o espectro da $r L m M I F 2$ em diferentes pHs, o que permite uma comparação de sua estrutura secundária. Observa-se que houve uma pequena mudança no perfil do espectro dessa proteína quando submetida aos pHs 3 a 7, onde observa-se um aumento de elipticidade maior na banda de 208nm do que na de 222nm. O espectro em pH 2,0 mostra que houve uma desorganização da estrutura secundária que, nesse $\mathrm{pH}$, perdeu o perfil de estrutura $\alpha / \beta$, apresentando um ombro na faixa de $215 \mathrm{~nm}$. A elipticidade negativa (MRE) da proteína nativa em 220nm cresce com a redução de pH indicando uma estrutura secundária um pouco mais pronunciada.

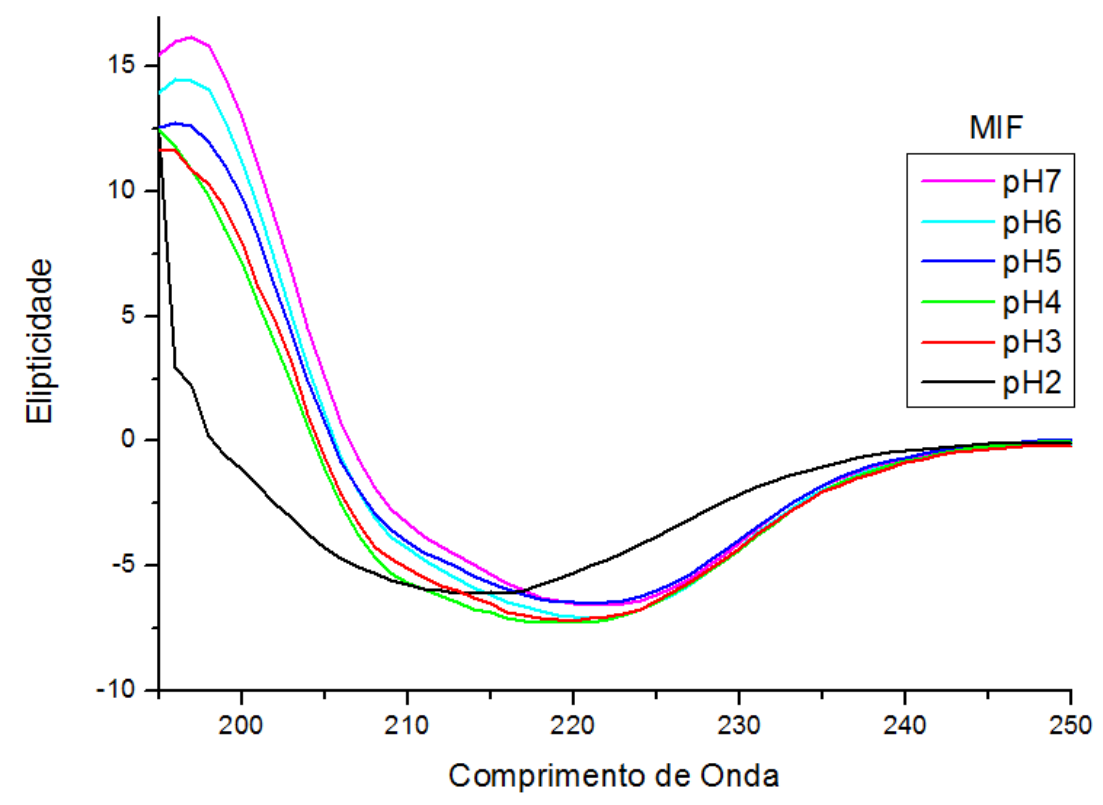

Figura 19: Análise por Dicroísmo Circular UV distante da proteína rLmMIF2 em função do pH. As medidas foram realizadas a $25^{\circ} \mathrm{C}$ com $100 \mu$ g de proteína em $200 \mu \mathrm{L}$ de tampão $20 \mathrm{mM}$ fosfato/citrato em pHs 7,0; 6,0; 5,0; 4,0 e 3,0. E tampão Glicina/HCl em pH2,0. 
A capacidade de manter a estrutura secundária em pHs muito ácidos pode indicar que rLmMIF2 encontra-se em estado de glóbulo fundido ("molten globule"), caracterizado por um estado compactado com estrutura secundária próxima à nativa (observada em CD UV distante), mas com estrutura terciária desordenada (confirmada por CD UV próximo) (Kelly et al., 1997). Esse estado foi confirmado, para $r L m M I F 2$, por análise com UV-próximo realizada nos pHs 3, 5 e 7 (Figura 20). Podemos observar que houve uma mudança acentuada na estrutura terciária com queda na elipticidade de $r L m M I F 2$. Resultado similar foi observado para MIF de mamíferos (Zerovnik et al., 1999).
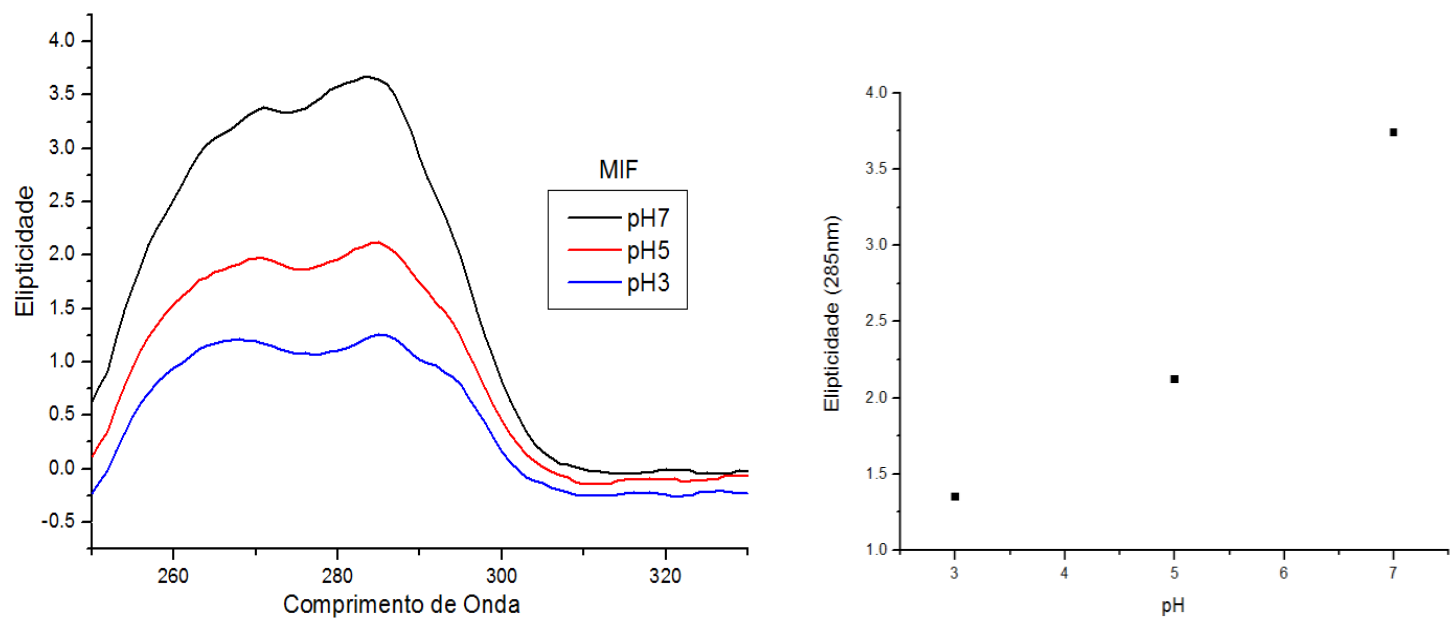

Figura 20: Análise por Dicroísmo Circular UV-próximo da proteína $r L m M I F 2$ em função do pH. As medidas foram realizadas a $25^{\circ} \mathrm{C}$ com $0,5 \mathrm{mg}$ de proteína em $1 \mathrm{~mL}$ de tampão $20 \mathrm{mM}$ fosfato/citrato em pHs 7,0 ; 5,0 e 3,0 .

O efeito do $\mathrm{pH}$ da solução na estrutura secundária das proteínas mutantes foi analisado com CD UV distante. Os espectros obtidos mostram que apesar das diferenças observadas entre $r L m M I F 2$ e os diferentes mutantes em $\mathrm{pH} 7$, todos, exceto o $\Delta 104-113$, apresentam comportamento semelhante a $r L m M I F 2$, apresentando uma estrutura secundária alterada apenas em pH2,0 (Figura 21). Esses resultados indicam que as mutações alteraram o perfil do espectro em $\mathrm{pH} 7,0$, porém não alteraram o perfil de variação de estrutura secundária sob diferentes pHs, mostrando que todos os mutantes em pHs baixos ainda possuem estrutura 
secundária similar ao pH 7,0. Resultados de CD UV próximo (Figura 22) mostraram que os mutantes P2G, W66L e W108F tiveram diminuição nos picos de elipticidade de acordo com a queda de pHs, mostrando uma diferença na estrutura terciária desses mutantes. Esse resultado, somado à estrutura secundária estável até $\mathrm{pH}$ 3,0, indicam o mesmo comportamento de rLmMIF2, com formação do estado de glóbulo fundido em baixos pHs. Observa-se nos espectros obtidos para os mutantes W66L e W108F que, de acordo com a redução do pH foram obtidos perfis de queda na elipticidade menos acentuados do que o observado para MIF2 recombinante. A utilização de agentes caotrópicos, como guanidina, poderão ajudar a caracterizar a formação de glóbulos fundidos nas proteínas mutantes de triptofano, inclusive a elucidar os papéis de cada aminoácido na estabilidade da proteína, durante a desnaturação.
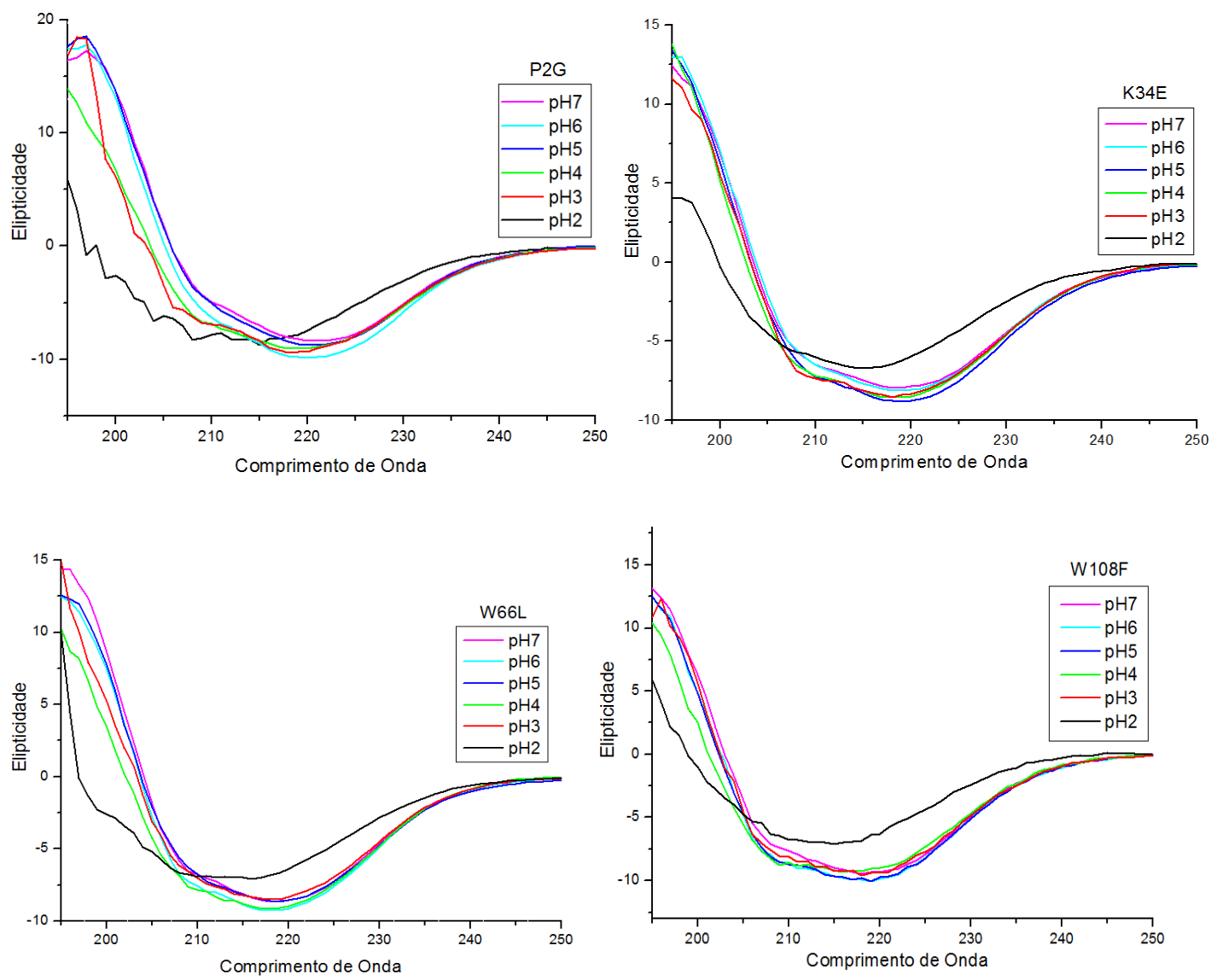

Figura 21: Análise por Dicroísmo Circular UV-distante dos mutantes de MIF em função do pH. As medidas foram realizadas a $25^{\circ} \mathrm{C}$ com $100 \mu$ g de proteína em $200 \mu \mathrm{L}$ de tampão $20 \mathrm{mM}$ fosfato/citrato em pHs 7,0; 6,0; 5,0; 4,0 e 3,0. E tampão Glicina/HCl em pH2,0. 

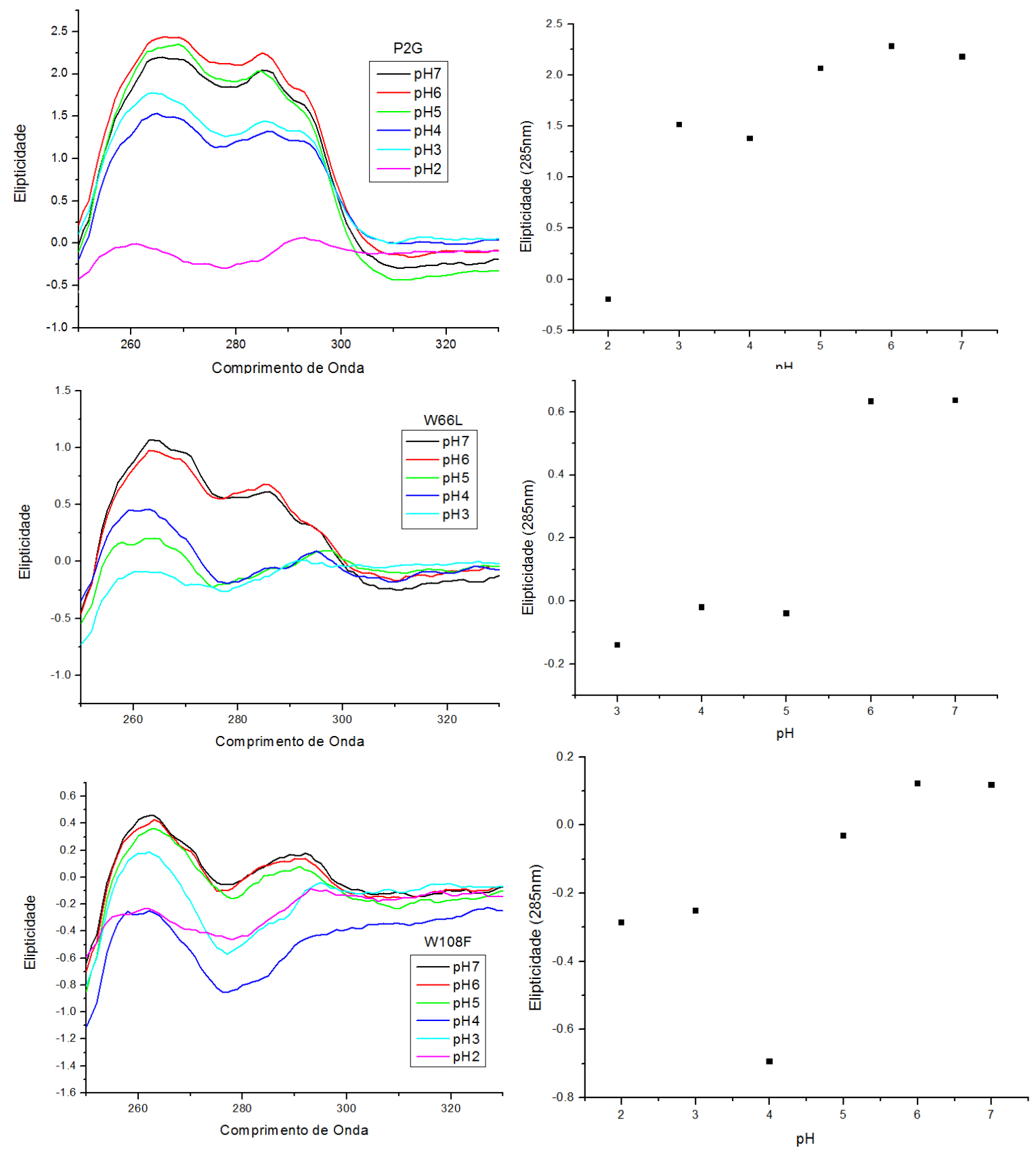

Figura 22: Análise por Dicroísmo Circular UV-próximo em função do pH. A) Mutante P2G; B) Mutante W66L; e C) W108F.

\subsubsection{Emissão de Fluorescência Intrínseca de Triptofanos (IFTE)}

Mudanças de conformação de proteínas podem ser detectadas pelos três resíduos intrinsicamente fluorescentes: triptofano, fenilalanina e tirosina, mas devido a maior rendimento quântico e maior sensibilidade da emissão de fluorescência à mudanças do 
ambiente, o triptofano tem sido mais usado para estudar tais mudanças de conformação (Lakowics, 1983). Ainda, a menor presença desse resíduo nas proteínas e a possibilidade de selecionar apenas a excitação de triptofano, em 295nm, fazem da análise de sua fluorescência intrínseca uma ferramenta de estudo de mudanças localizadas na estrutura de proteínas (Royer, 2006).

A proteína $r L m M I F 2$ possui dois resíduos de triptofano localizados na posição 66 e 108, e os espectros de emissão de fluorescência intrínseca dessa proteína e dos mutantes podem detectar variações no microambiente desses aminoácidos e fornecer informações importantes sobre possíveis mudanças de conformação devido à variação de $\mathrm{pH}$ da solução. Os espectros de IFTE da proteína $r L m M I F 2$ em função do pH estão representados na Figura 23. Nesta figura observa-se em pH 7, $\lambda$ máx em 340nm, que é característico de triptofanos em proteínas com estrutura terciária organizada e, verifica-se que, de acordo com a diminuição do pH da solução, ocorreu um aumento gradativo na intensidade de fluorescência de $\mathrm{pH}$ 6,0 para pH 2,0. Em geral, com a desnaturação espera-se uma exposição dos triptofanos ao solvente e conseqüente queda na emissão de fluorescência acompanhada de uma mudança no pico máximo para a região do vermelho do espectro (Lakowics, 1983), situação contrária aos resultados apresentados pela $r L m M I F 2$. Situações em que a fluorescência aumenta com ambientes de desnaturação são, geralmente, resultantes de uma possível supressão de fluorescência ocorrida no estado enovelado (no caso, $\mathrm{pH} 7,0$ ) que desaparece com a mudança de microambiente (nesse caso, pHs ácidos), tornando a intensidade de emissão maior em ambientes de exposição ao solvente (Royer, 2006). Embora a emissão de um triptofano inserido, mesmo parcialmente, dentro da matriz de uma proteína tenha, normalmente, uma mudança do $\lambda \max$ de emissão para o vermelho (red-shift) em uma desnaturação, é difícil prever o efeito da exposição ao solvente no rendimento quântico (intensidade de emissão) (Royer, 2006). Isto é devido ao fato de que várias cadeias de aminoácidos (lisina, tirosina, 
glutamina, asparagina, acido glutâmico, ácido aspártico, cisteína e histidina) (Chen \& Barkely, 1998) bem como a ligação peptídica (Adams et al., 2002), e ligação dissulfeto (Cowgill, 1970) podem atuar como supressores da fluorescência de triptofano. No caso da rLmMIF2, segundo sua estrutura tridimensional monomérica (PDB:3FWT) o triptofano 66 está circundado de até 10 Å por Phe113, Cys106, Lys104 e Trp108, e este último, circundado até $10 \AA$ Å por Asn109, Met39, Glu36, Phe37 e Trp66. Possivelmente esse microambiente, e sua disposição tridimensional resultante, permitiria um ambiente de supressão de fluorescência e/ou uma transferência de energia por ressonância que poderia resultar na menor emissão em pH7.0. É importante ressaltar que a rLmMIF2 foi encontrada como trímero no cristal e, como mostramos, dímero em solução, e possivelmente outros resíduos poderiam atuar como supressores na estrutura quaternária.

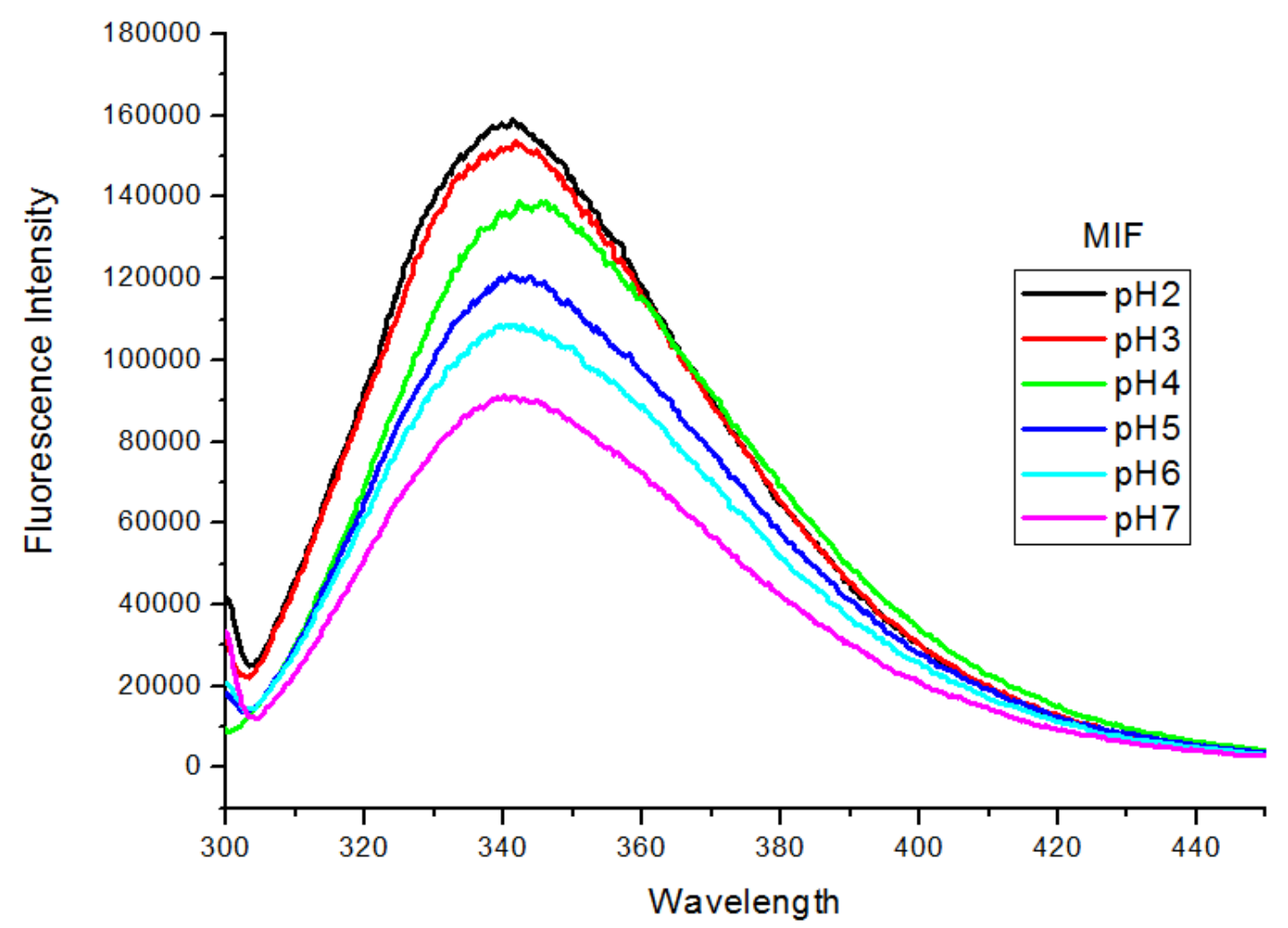

Figura 23: Análise por espectroscopia de fluorescência da proteína $r$ LmMIF2 em função do pH. As medidas foram realizadas a $25^{\circ} \mathrm{C}$ com $0,060 \mu \mathrm{g} / \mathrm{mL}$ de proteína em tampão $20 \mathrm{mM}$ fosfato/citrato em pHs 7,0 ; 6,0; 5,0; 4,0 e 3,0 e tampão Glicina/ $\mathrm{HCl}$ pH 2,0. 
O pico de emissão máxima ( $\lambda$ máx) foi levemente deslocado para a região do vermelho (red shift) apenas no $\mathrm{pH} 4$, indicando alteração nos microambientes dos triptofanos da proteína nesse $\mathrm{pH}$. Pode ser inferido que a estrutura em baixo $\mathrm{pH}$ aumenta a intensidade de fluorescência do triptofano sem um detectável aumento de hidrofobicidade dos microambientes dos mesmos. A indicação do estado de glóbulo fundido foi observada por dicroísmo circular, as pequenas alterações na estrutura secundária com a queda do $\mathrm{pH}$ e as alterações na estrutura terciária possivelmente resultam nessa pequena mudança no $\lambda$ máx. Resultados similares foram obtidos para MIF de mamíferos (Zerovnik, 1999).

Os mutantes de MIF foram submetidos à uma variação do $\mathrm{pH}$ da solução e experimentos de fluorescência foram realizados afim de verificar o comportamento dessas proteínas (Figura 24). O mutante P2G mostrou, como para rLmMIF2, efeito de supressão em pH 7,0, em relação a pH mais baixos. Entretanto em relação à rLmMIF2 nota-se uma mudança no $\lambda$ máx de emissão para $345 \mathrm{~nm}$ (red shift) nos pHs $7,6,5$ e 4, indicando uma maior exposição dos triptofanos nesse mutante. Importante notar que nos pHs 3 e 2, houve um $\lambda$ máx em 340nm (similar ao da rLmMIF2) indicando um aumento de hidrofobicidade em relação aos pHs mais altos no mutante $\mathrm{P} 2 \mathrm{G}$.

O mutante K34E não apresentou um aumento de intensidade com a queda do $\mathrm{pH}$, indicando a diminuição do efeito de supressão mostrado para a $r L m M I F 2$ (Figura 24). O $\lambda$ máx deste mutante mostrou-se deslocado para a região do vermelho, 350nm, quando comparado a rLmMIF2, porém a desnaturação não provocou deslocamento desse pico. Esse resíduo, K34, está presente em uma alça que liga a extremidade C-terminal da hélice $\alpha 1$ na estrutura $\beta 2$, e a mutação não-conservativa, para ácido glutâmico poderia alterar demasiadamente a estrutura dessa região da proteína, inclusive reposicionando a alça C-terminal da proteína. Essa alça que se localiza entre a Lys34 e o Trp66, e uma mudança na sua posição poderia resultar em 
uma alteração de posição do Trp66 alterando a exposição e/ou polaridade desse resíduo e, assim, diminuir o efeito de supressão e alterar o $\lambda$ máx.
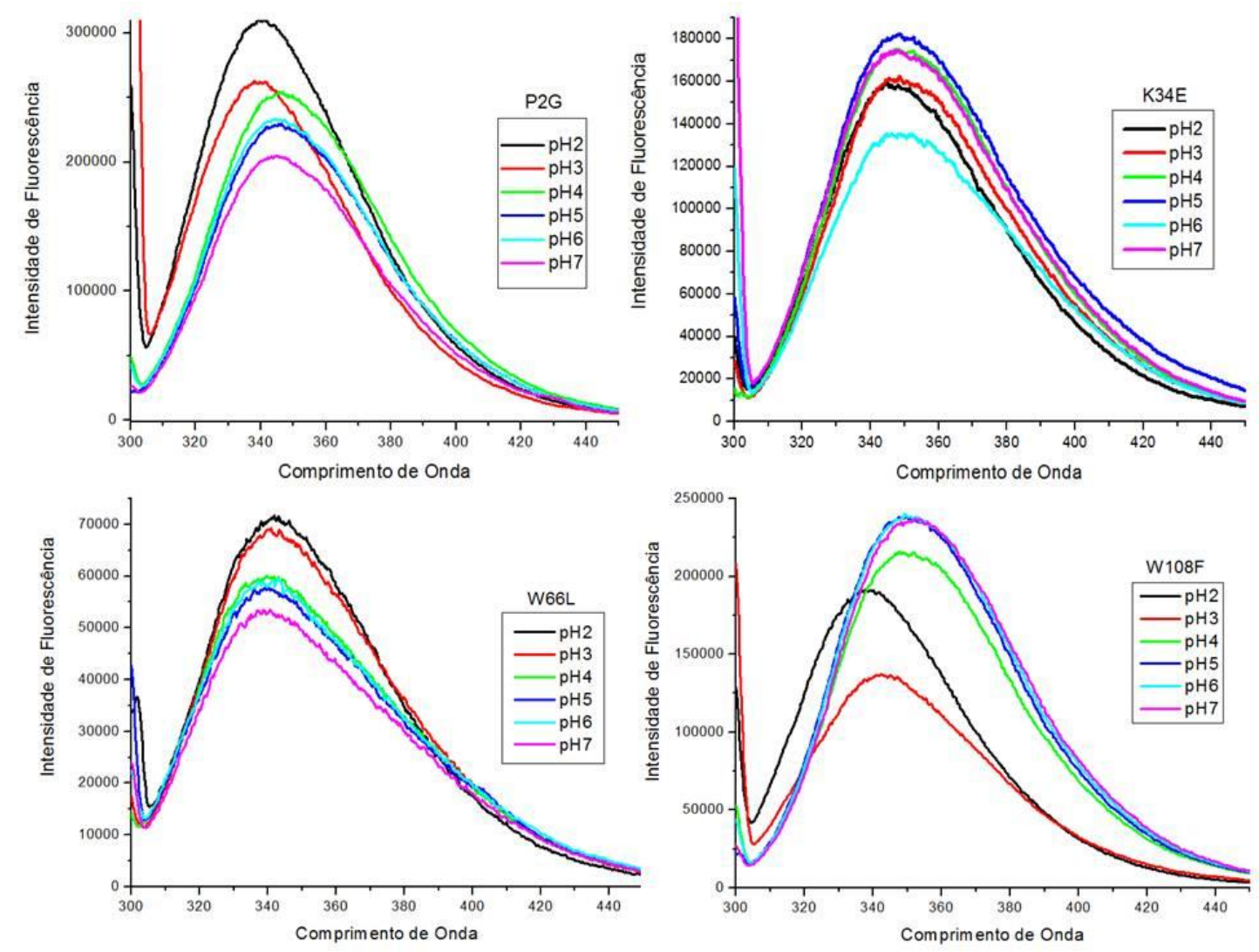

Figura 24: Análise por espectroscopia de fluorescência dos mutantes P2G, K34E, W66L e W108F em função do pH. As medidas foram realizadas a $25^{\circ} \mathrm{C}$ com $0,060 \mu \mathrm{g} / \mathrm{mL}$ de proteína em tampão $20 \mathrm{mM}$ fosfato/citrato em pHs 7,0; 6,0; 5,0; 4,0 e 3,0 e tampão Glicina/HCl pH 2,0.

A emissão de fluorescência da proteína sem o triptofano na posição 66 (W66L) (Figura 24) foi cerca de $60 \%$ menor do que a da $L m M I F 2$ recombinante, em média, para todos os pHs, mostrando que esse resíduo dá a maior contribuição para a fluorescência das proteínas aqui estudadas. Independentemente dessa redução acentuada na emissão, observa-se um aumento de emissão com a queda do pH, também observado para as outras proteínas, indicando que nesse mutante, o W108, apresenta uma emissão suprimida no estado enovelado em $\mathrm{pH} 7,0$.

Analisando os espectros do mutante W108F (Figura 24), em que se detecta fluorescência do W66, observa-se que a intensidade de fluorescência está cerca de três vezes 
maior que a da $r L m M I F 2$ selvagem, quase 1,5 vezes maior que a do P2G e K34E e 5 vezes maior que o W66L. Esse resultado indica que a supressão do estado enovelado, mostrado para a $r L m M I F 2$, quase foi extinta pela conformação da estrutura do mutante W108F. Além disso, confirmando a indicação de extinção da supressão, observa-se um comportamento de queda de intensidade de fluorescência com a diminuição do pH. Esse resultado, contrário ao das outras proteínas desse estudo, em que há supressão no estado enovelado, mostra o comportamento geral encontrado para desnaturação de proteínas, em que tem sido sugerida uma exposição do triptofano ao solvente e diminuição da sua intensidade de emissão. O deslocamento do $\lambda$ máx para $350 \mathrm{~nm}$ no estado enovelado nos pHs 7, 6, 5 e 4 confirma uma maior exposição do W66 no mutante W108F.

Os resultados obtidos com o mutante $\mathrm{W} 108 \mathrm{~F}$ sugerem que o mesmo poderia ser o mais indicado para estudos de avaliação da estabilidade da LmMIF2 em solução, pois possui um triptofano único apresentando um comportamento de emissão de fluorescência mais comumente encontrado em desnaturações. Inicialmente, com esse resultado de variação de $\mathrm{pH}$, pode ser salientado uma indicação de mudança na estrutura terciária ou quaternária abaixo do pH5,0, sugerida pela pequena variação de intensidade de emissão, sem deslocamento de $\lambda \max$, até esse $\mathrm{pH}$. Somado a essa inferência, a queda de emissão e deslocamento para o azul do espectro ("blue shift") do $\mathrm{pH} 4,0$ para $\mathrm{pH} 3,0$ pode indicar que essa proteína já se encontra em um estado de glóbulo fundido em pH3,0 e, em pH2,0, com aumento de emissão, já abaixo de 340nm pode indicar que, nesse $\mathrm{pH}$, o triptofano encontra-se em um ambiente de maior hidrofobicidade, proporcionado pelo estado de glóbulo fundido. Estudos de desnaturação, usando agentes caotrópicos, como guanidina e uréia, possibilitarão uma caracterização dessas mudanças de conformação indicadas pela queda do $\mathrm{pH}$, inclusive um acompanhamento de dissociação do dímero observado nesse estudo, e, possivelmente, 
uma caracterização da formação do estado glóbulo fundido e suas implicações na estrutura da LmMIF2.

\subsection{Efeito das mutações na atividade funcional da $r L m M I F 2$}

Com o objetivo de investigar se a proteína recombinante $r L m$ MIF2 e MIF mutantes: P2G, K34E, W66L, W108F e $\Delta 104-113$ expressas em E. coli, possuíam atividade funcional foram realizados ensaios de interação com macrófagos a fim de avaliar os efeitos dessas proteínas heterólogas na migração dessas células. A produção de proteínas recombinantes a partir de E. coli possui uma limitação que é a contaminação da proteína de interesse com endotoxinas da bactéria, que são um conjunto de complexos lipopolissacarídeos (LPS) que ativam a migração de macrófagos. Dessa forma, foram realizados ensaios com o objetivo de verificar se as proteínas heterólogas purificadas induziriam a migração de macrófagos quando comparadas ao LPS comercial, que foi utilizado como controle positivo. Na Figura 25 observa-se que tanto LmMIF2, quanto os mutantes de MIF, quando comparados ao controle negativo (meio), não induziram a migração de macrófagos, ou induziram-na suavemente, sugerindo que uma possível contaminação com LPS bacteriano, se existente, seria muito baixa, pois há muitas lavagens de coluna na cromatografia e uma diálise durante o protocolo de purificação. É importante salientar os MIFs humano (Weiser et al., 1991, Pastrana et al., 1998) e de patógenos como de $P$. falciparum (Cordery et al. 2007) e de B. malayi (Pastrana et al., 1998), Ancylostoma ceylanicum (Cho et al., 2008), que foram descritos como ativadores de macrófagos e indutores de migração aleatória, mas também de inibidores de migração por quimiotaxia, dependendo de circunstâncias experimentais específicas. 


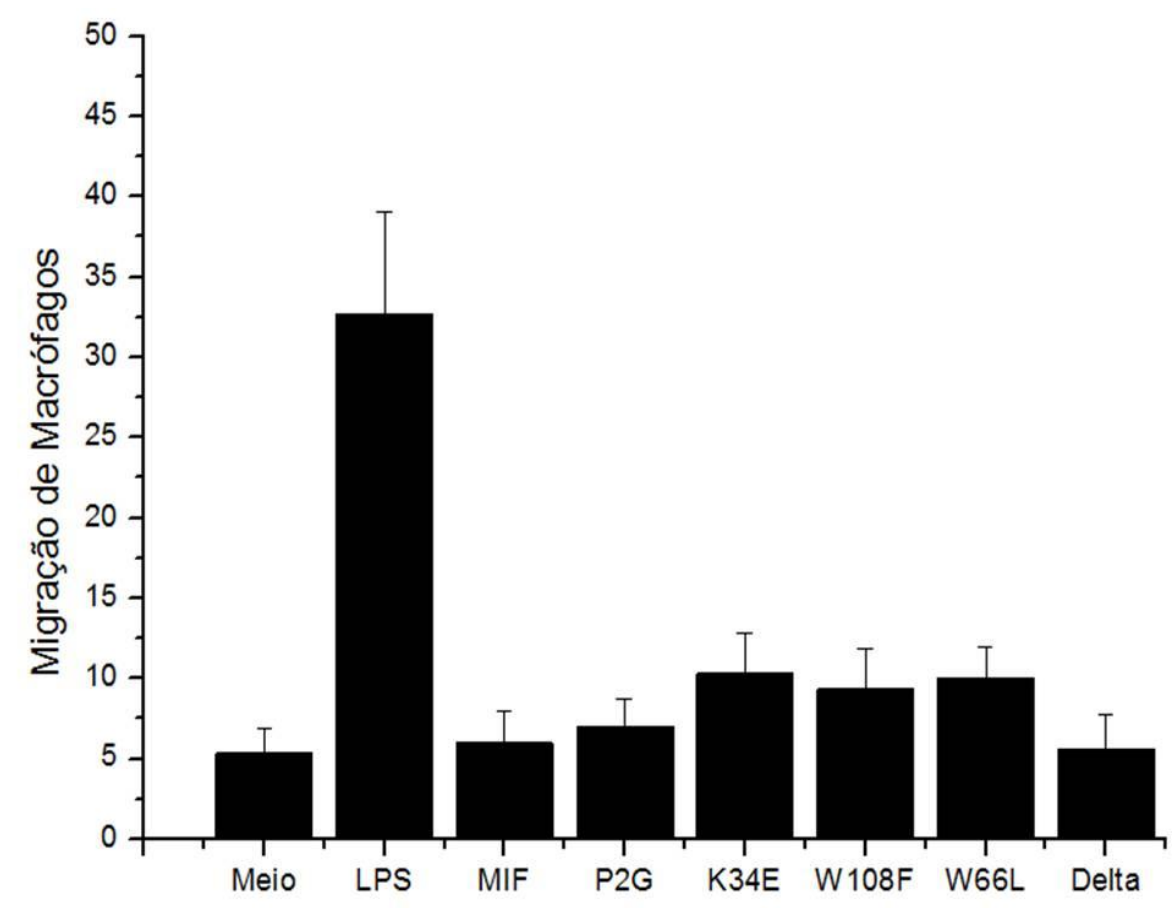

Figura 25: Ensaio de migração de macrófagos na presença da proteína recombinante $L m M I F 2$ e mutantes. Para análise de migração foram utilizadas $7 \times 10^{4}$ macrófagos cultivados na presença de LPS 100ng, MIF e mutantes 100ng. A migração de macrófagos foi determinada a partir do número de células que passaram da faixa central criada na lâmina.

Um peptídeo natural, a polimixina $\mathrm{B}$, é um potente antibiótico que liga-se ao LPS neutralizando-o. Trata-se de um decapeptídeo cíclico catiônico, que contém grupamentos lipofílicos e hidrofílicos que ligam-se aos lipídios A, componentes majoritários das endotoxinas (Cardoso, 2007). Na Figura 26 é mostrado o ensaio de migração com a utilização de polimixina que testou presença de LPS como contaminante nas proteínas purificadas de $E$. coli. Os resultados mostraram que apenas as proteínas K34E, W66L e $\Delta 104-113$ apresentaram uma pequena diminuição na migração de macrófagos se comparada ao ensaio sem polimixina, indicando que, se presente nas amostras, o LPS não altera o perfil das proteínas na migração das células. Ainda, pode ser concluído que essa presença não é resultante falha do protocolo purificação, pois todas as proteínas foram purificadas com o mesmo protocolo, mas nem todas apresentaram indícios de contaminação por LPS. 


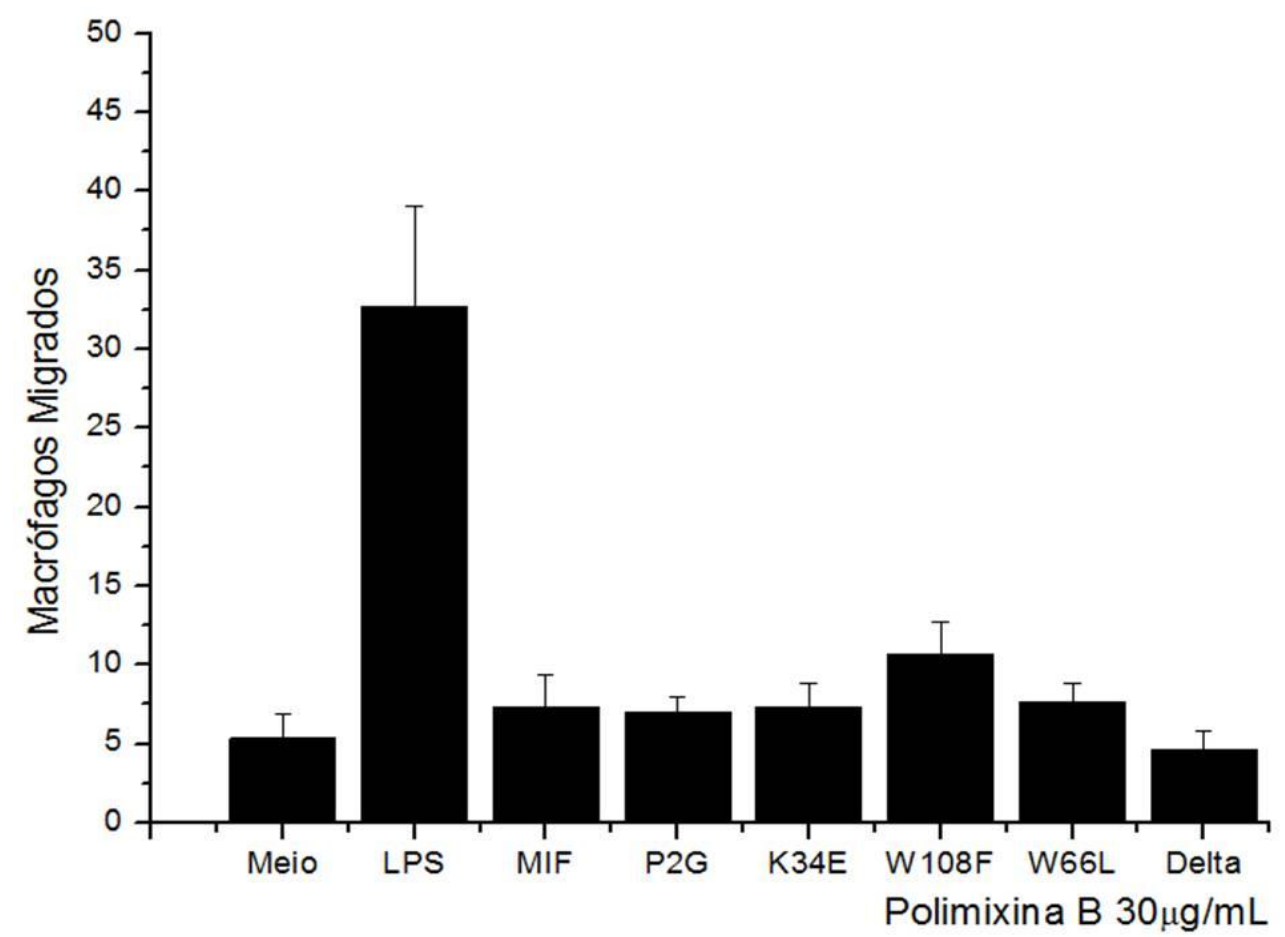

Figura 26: Ensaio de migração de macrófagos com LmMIF2 e mutantes na presença de Polimixina B. Para análise de migração foram utilizadas $7 \times 10^{4}$ macrófagos cultivados na presença de Polimixina B 30 $\mu \mathrm{g} / \mathrm{mL}$.

O efeito das mutações na atividade de inibição de migração de macrófagos está apresentado na Figura 27 em que as células foram pré-incubadas com $L m M I F 2$ e os mutantes e, posteriormente, incubadas com LPS. Na Figura 27 pode ser observado que a LmMIF2 inibiu a migração dos macrófagos em 75\%, comparado com a migração induzida por LPS. Essa inibição já foi demonstrada para outros MIFs de parasitas como de Plasmodium falciparum, Plasmodium berghei, Brugia malayi, Plasmodium falciparum e Trichinella spiralis (Pastrana et al., 1998; Tan et al., 2001; Augustijn et al., 2007; Cordery et al., 2007; Shao et al., 2008).

As proteínas mutantes P2G, K34E, W108F, W66L e $\Delta 104-113$ inibiram menos a migração de macrófagos (entre 44 e 50\%) se comparadas à LmMIF2. No MIF humano foi mostrado que a substituição do aminoácido prolina 2, essencial para a atividade de tautomerização in vitro, para uma serina não interferiu na atividade de inibição de migração, mostrando que essa atividade tautomerase não é essencial para a atividade funcional (Bendrat, 
1997; Swope et al., 1998, Hermanowski-Vosatka et al., 1999). Esse mesmo resultado foi obtido com a P2G de L. major que mostrou uma inibição similar à recombinante selvagem, indicando que as mudanças observadas na estrutura em solução, em relação à $r L m M I F 2$, não interferem na interação com o receptor do macrófago.

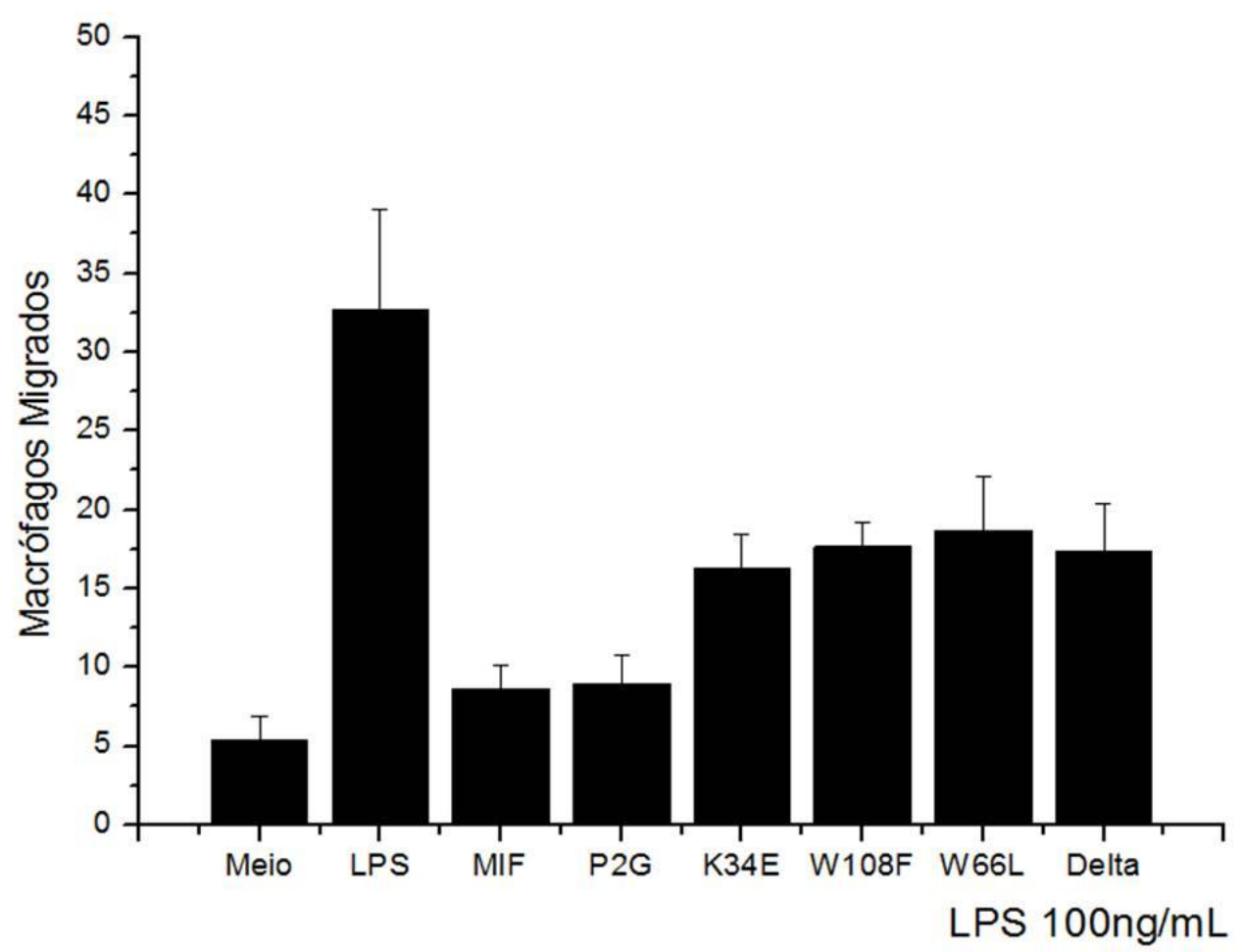

Figura 27: Ensaio de migração de macrófagos pré-incubados com $L m M I F 2$ e mutantes e incubados com 100ng/mL de LPS.

Mutantes do MIF humano deletados de 5 e 10 aminoácidos na porção C-terminal mostraram diferenças na estabilidade estrutural, mas não apresentaram diferenças de ligação para o receptor CD74 (El-Turk et al., 2008). Como observado na Figura 27, o mutante $\Delta 104$ 113 mostrou uma diminuição de atividade de inibição, mesmo apresentando uma estrutura parcialmente secundária desorganizada (mostrada por dicroísmo circular), indicando a importância dessa alça para o dímero da $L m M I F 2$ na interação com receptor. Os mutantes K34E e W66L também mostraram uma atividade menor de inibição de migração e, sugerem uma importância dos mesmos para a atividade funcional. Até a finalização dessa dissertação, 
não foi encontrado, na literatura, descrição da importância das posições 34 e 66 (ou de posições similares) para a atividade de inibição de migração de células.

Os resultados de migração mostraram que, com exceção do $\mathrm{P} 2 \mathrm{G}$, as mutações inibiram menos (entre 44 e 50\%) a migração de macrófagos, mesmo tendo a mesma estrutura quaternária que a $L m M I F 2$ recombinante. Assim, pode-se inferir que alterações na estrutura secundária e/ou terciária, possivelmente, foram responsáveis por essa diferença de atividade funcional. Os experimentos de dicroísmo circular e fluorescência do triptofano mostraram que as proteínas mutadas possuem diferenças estruturais e, essas alterações na estrutura podem estar envolvidas direta ou indiretamente na interação com o receptor, diminuindo sua interação e possibilitando a atuação do LPS como indutor de migração. 
5. Considerações EFinais 


\section{Considerações Finais}

$\checkmark$ A mutagênese sítio-dirigida e a clonagem da MIF recombinante e dos mutantes P2G, K34E, W66L, W108F e Delta (104-113) foram bem sucedidas;

$\checkmark$ As proteínas MIF e mutantes foram expressas em E. coli e purificadas do extrato solúvel da bactéria por cromatografia de afinidade utilizando resina de Níquel;

$\checkmark$ Experimentos de filtração em gel revelaram que as mutações não alteraram o oligômero dos mutantes, estando estes presentes em solução na forma dimérica, como a $r L m M I 2 F$ selvagem;

$\checkmark$ A análise dos espectros de dicroísmo circular revelou que a mudança de apenas um aminoácido alterou a estrutura secundária das proteínas mutantes e que mutantes adotaram um estado de glóbulo fundido em baixos pH como a $r L m M I F$ selvagem;

$\checkmark$ Os experimentos de fluorescência intrínseca do triptofano indicaram uma possível supressão de fluorescência na faixa de $\mathrm{pH} 7,0$ para a $r L m M I F$ e mutantes, exceto o W108F. Ainda, que o W66 representa aproximadamente $60 \%$ da fluorescência total da $r L m M I F$ e que a conformação da proteína na ausência do W108 permitiu uma emissão maior sem efeito supressor observado.

$\checkmark$ No ensaio de migração de macrófagos foi observado que as mutações não anularam, mas diminuíram (exceto o P2G), o efeito inibitório de migração e que os mutantes K34E, W108F, W66L e $\Delta$ 104-113 inibiram menos a migração possivelmente, segundo os dados espectroscópicos, por uma diferença estrutural em relação à rLmMIF selvagem. 


\section{Referências Bibliográficas}




\section{Referências Bibliográficas}

Abu-Raddad, L. J.; Patnaik, P. and Kublin, J. G; (2006) Dual Infection with HIV and Malaria Fuels the Spread of Both Diseases in Sub-Saharan Africa. Science, v.314(5805): 1603 - 1606.

Adams, P. D.; Chen, Y.; Ma, K.; Zagorski, M. G.; Sonnichsen, F. D.; McLaughlin, M. L.; Barkley, M. D. (2002) Intramolecular quenching of tryptophan fluorescence by the peptide bond in cyclic hexapeptides. J. Am. Chem. Soc. 124(31), 9278-86.

Alves, L. V.; Canto-Cavalheiro, M. M. do; Cysne-Finkelstein, L.; Leon, L.; (2003) In vitro antiproliferative Effects of Several Diaryl Derivatives on Leishmania spp. Biological \& Pharmaceutical Bulletin, v.26(4): 453 - 456.

Albuquerque, M. E. L. de; (2006) Infecção de macrófagos originados de monócitos primários humanos com o parasito L. amazonensis em microambientes normóxico e hipóxico. [Mestrado] Universidade Estadual de Campinas - UNICAMP.

Andrade M. A., Chacon P., Merelo J. J., Moran F. (1993) Evaluation of secondary structure of proteins from UV circular dichroism spectra using an unsupervised learning neural network. Protein Eng 6: 383-90

Ashfold, R. W.; Desjeux, P. \& Deraadt, R. P.; (1992) Estimation of population at risk of infection and number of cases of leishmaniasis. Parasitology Today, 8:103-104.

Augustijn K. D., Kleemann R., Thompson J., Kooistra T., Crawford C. E., Reece S. E., Pain A., Siebum A. H., Janse C. J., Waters A. P. (2007) Functional characterization of the Plasmodium falciparum and $\mathrm{P}$. berghei homologues of macrophage migration inhibitory factor. Infect Immun 75: 1116 - 1128.

Bacher, M.; Metz, C. N.; Calandra, T.; Mayer, K.; Chesney, J.; Lohoff, M.; Gemsa, D.; Donnelly, T. and Bucala, R.; (1996) Proc. Natl. Acad. Sci. USA. v. 93: 7849-7854.

Balaña-Fouce, R; Reguera, R.M.; Cubría, C.; Ordóñez, D.; Review: The Pharmacology of Leishmaniasis. General Pharmacology, v.30(4): 435 - 443, 1998.

Basano, S. A. \& Camargo, L. M. A.; (2004) Leishmaniose tegumentar americana: histórico, epidemiologia e perspectivas de controle. Rev. Bras. de Epidemiologia, v.7(3): 328 - 377.

Bendrat, K.; Al-Abed, Y.; Callaway, D. J. E.; Peng, T.; Calandra, T.; Metz, C. N. and Bucala, R.; (1997) Biochemical and Mutational Investigations of the Enzymatic Activity of Macrophage Migration Inhibitory Factor. Biochemistry, v.36: 1535615362.

Bernhagen, J., Calandra, T., Mitchell, R. A., Martin, S. B., Tracey, K. J., Voelter, W., Manogue, K. R., Cerami, A., and Bucala, R. (1993) MIF is a pituitary-derived cytokine that potentiates lethal endotoxaemia Nature 365: 756 - 759.

Bernhagen J., Mitchell R. A.,Calandra T., Voelter W., Cerami A., Bucala R. (1994)

Purification, bioactivity and secondary structure analysis of mouse and human macrophage migration inhibitory factor (MIF). Biochemistry 33: 14144-55.

Bloom, B. R., and Bennett, B. (1966) Mechanism of a reaction in vitro associated with delayed-type hypersensitivity Science 153: $80-82$

Bozza M.; Satoskar A. R.; Lin, G.; Lu, B.; Humbles, A. A.; Gerard, C.; (1999) Targeted disruption of migration inhibitory factor gene reveals its critical role in sepsis. J Exp Med. v.189: 341 - 346.

Boxer, D.H.; Zhang, H.; Gourley, D. G.; Hunter, W. N.; Kelly, S. M.; Price, N.C. (2004) Sensing of remote oxyanion binding at the DNA binding domain of the molybdate-dependent transcriptional regulator, ModE, Org. Biomol. Chem. 2: 28292837. 
Bradford M. M. (1976) A rapid and sensitive method for the quantitation of microgram quantities of protein utilizing the principle of protein-dye binding. Anal Biochem 72: 248-54

Bucala, R., and Donnelly, S. C. (2007) Macrophage migration inhibitory factor: a probable link between inflammation and cancer. Immunity v.26: $281-285$.

Calandra, T.; Bernhagen, J.; Metz, C. N.; Spiegel, L. A.; Bacher, M.; Donnelly, T.; Cerami, A.; and Bucala, R. (1995) MIF as a glucocorticoid-induced modulator of cytokine production Nature 377: 68 - 71 .

Calandra, T.; Echtenacher, B.; Roy, D. L.; Pugin, J.; Metz, C. N.; Hultner, L.; Heumann, D.; Mannel, D.; Bucala, R.; and Glauser, M. P.; (2000) Protection from septic shock by neutralization of macrophage migration inhibitory factor Nat. Med. 6: $164-170$.

Calandra, T. (2003) Macrophage migration inhibitory factor and host innate immune responses to microbes Scand J. Infect. Dis. v.35: 573 - 576.

Calandra, T. \& Roger, T.; (2003) Macrophage Migration Inhibitory Factor: A regulator of innate immunity. Nature. 3: $791-800$.

Calandra, T., Froidevaux, C., Martin, C., and Roger, T. (2003) Macrophage migration inhibitory factor and host innate immune defenses against bacterial sepsis J. Infect. Dis. 187 (2): 385 - 390.

Cardoso, L. S.; Araújo, M. I; Góes, A. M.; Pacífico, L. G.; Oliveira, R. R. and Oliveira, S. C. (2007) Polymyxin B as inhibitor of LPS contamination of Schistosoma mansoni recombinant proteins in human cytokine analysis Microbial Cell Factories, 6:1

Chang K. P. \& Chaudhuri G., Fong D. (1990) Molecular determinants of Leishmania virulence. Annu Rev Microbiol v.44: 499-529.

Chen Y and Barkley MD. (1998). Towards understanding tryptophan fluorescence. Biochemistry 37 (28), pp 9976-9982.

Cho, Y.; Jones, B. F.; Vermeire, J. J.; Leng, L.; DiFedele, L.; Harrison, L. M.; Xiong, H.; Kwong, Y. K.; Chen, Y.; Bucala, R.; Lolis, E.; Cappello, M. (2007) Structural and functional characterization of a secreted hookworm Macrophage Migration Inhibitory Factor (MIF) that interacts with the human MIF receptor CD74. J Biol Chem. v. 282(32): 23447-56.

Cho, M. (2008) Coherent Two-Dimensional Optical Spectroscopy Chem. Rev., v.108 (4), pp 1331-1418

Cordery, D. V.; Kishore, U.; Kyes, S.; Shafi, M. J.; Watkins, K. R.; Williams, T. N.; Marsh, K.; Urban, B. C.; (2007). Characterization of a Plasmodium falciparum macrophage-migration inhibitory factor homologue. J Infect Dis. v.195(6):905-912.

Cowgill RW. (1970) Fluorescence and the structure of proteins. XVIII. Spatial requirements for quenching by disulfide groups. Biochim Biophys Acta 207:556559.

David J. R. (1996) Delayed hypersensitivity in vitro: Its mediation by cell-free substances formed by lymphoid cell-antigen interaction. Proc Natl Acad Sci USA 56: $72-77$.

De Oliveira, A. H. C.; Cruz, A. K.; Greene, L. J.; Rosa, J. C.; Ward, R. J.; (2006) Subproteomic analysis of soluble proteins of the microsomal fraction from two Leishmania species. Comp. Biochem. Physiol Part D 3: 300-308.

El-Turk, F.; Cascella, M.; Ouertatani-Sakouhi, H.; Narayanan, R. L.; Leng, L.; Bucala, R.; Zweckstetter, M.; Rothlisberger, u. Lashuel, H. A.; (2008) The Conformational Flexibility of the Carboxy Terminal Residues 105\#114 Is a Key Modulator of the Catalytic Activity and Stability of Macrophage Migration Inhibitory Factor. Biochem. 47 (40): 10740 - 10756. 
Fasman, G.D., Circular Dichroism and the Conformational Analysis of Biomolecules (1996) Plenum Press, New York.

Fingerle-Rowson, G.; Koch, P.; Bikoff, R.; Lin, X.; Metz, C. N.; Dhabhar, F. S.; Meinhardt, A.; and Bucala, R. (2003) Regulation of macrophage migration inhibitory factor expression by glucocorticoids in vivo Am. J. Pathol. 162: 47 - 56.

Fingerle-Rowson, G.; Petrenko, O.; Metz, C. N.; Forsthuber, T. G.; Mitchell, R.; Huss, R.; Moll, U.; Muller, W. and Bucala, R. (2003) The p53-dependent effects of macrophage migration inhibitory factor revealed by gene targeting Proc. Natl. Acad. Sci. U.S.A. v.100: 9354 - 9359.

Flaster, H.; Bernhagen, J.; Calandra, T.; Bucala, T.; (2007) The macrophage migration inhitory factor-glucocorticoid dyad: regulation of inflammation and immunity. Mol. Endocrinol. v.21, $1267-1280$.

Galat A.; Riviere, S.; Bouet, F.; (1993) Purification of macrophage migration inhibitory factor (MIF) from bovine brain cytosol. FEBS Lett. 319: 233-236.

Hanahan, D.; (1983) Studies on transformation of Escherichia coli with plasmids. J. Mol. Biol., 166: 557-580.

Handman, E.; (2001) Leishmaniasis: current status of vaccine development. Clinical Microbiology Reviews, v.14(2): 229 - 243.

Hepburn, N. C.; (2000) Cutaneous leishmaniasis. Clinical and Experimental Dermatology, v.25: 363 - 370.

Hermanowski-Vosatka, A.; Mundt, S. S.; Ayala,J. M.; Goyal, S.; Hanlon, W. A.; Czerwinski, R. M.; Wright, S. D. and Whitman, C. P. (1999) Enzymatically Inactive Macrophage Migration Inhibitory Factor Inhibits Monocyte Chemotaxis and Random Migration Biochemistry,v.38 (39):12841-12849

Hoi, A. Y.; Iskander, M. N. and Morand, E. F; (2007) Macrophage migration inhibitory factor: a therapeutic target across inflammatory diseases Inflammation Allergy Drug Targets 6: $183-190$.

Ivens A. C., Peacock C. S., Worthey E. A., Murphy L., Aggarwal G., Berriman M., Sisk E.,Rajandream M. A., Adlem E., Aert R., Anupama A., Apostolou Z., Attipoe P., Bason N., Bauser C., Beck A., Beverley S. M., Bianchettin G., Borzym K., Bothe G., Bruschi C. V., Collins M., Cadag E., Ciarloni L., Clayton C., Coulson R. M., Cronin A., Cruz A. K., Davies R. M., De Gaudenzi J., Dobson D. E., Duesterhoeft A., Fazelina G., Fosker N., Frasch A. C., Fraser A., Fuchs M., Gabel C., Goble A., Goffeau A., Harris D., Hertz-Fowler C., Hilbert H., Horn D., Huang Y., Klages S., Knights A., Kube M., Larke N., Litvin L., Lord A., Louie T., Marra M., Masuy D., Matthews K., Michaeli S., Mottram J. C., Muller-Auer S., Munden H., Nelson S., Norbertczak H., Oliver K., O'Neil S., Pentony M., Pohl T. M., Price C., Purnelle B., Quail M. A., Rabbinowitsch E., Reinhardt R., Rieger M., Rinta J., Robben J., Robertson L., Ruiz J. C., Rutter S., Saunders D., Schafer M., Schein J., Schwartz D. C., Seeger K., Seyler A., Sharp S., Shin H., Sivam D., Squares R., Squares S., Tosato V., Vogt C., Volckaert G., Wambutt R., Warren T., Wedler H., Woodward J., Zhou S., Zimmermann W., Smith D. F., Blackwell J. M., Stuart K. D., Barrell B., et al. (2005) The genome of the kinetoplastid parasite, Leishmania major. Science 309: $436-442$.

Jaworski, C.J.; Moreira, E.; Li, A.; Lee, R. and Rodriguez, I. R.; (2001) A family of 12 human genes containing oxysterol-binding domains. Genomics v.78: 185 - 196.

Juttner, S.; Bernhagen, J.; Metz, C. N.; Rollinghoff, M.; Bucala, R. and Gessner, A.; (1998) Migration inhibitory factor induces killing of Leishmania major by macrophages: dependent on reactive nitrogen intermediates and endogenous TNF- $\alpha$. J. Immunol. 161(5):2383-2390. 
Kamir, D.; Zierow, S.; Leng, L.; Cho, Y.; Diaz, Y.; Griffith, J.; McDonald, C.; Merk, M.; Mitchell, A.; Trent, J.; Chen, Y.; Kwong, Y. K. A.; Xiong, H.; Vermeire, J.; Cappelio, M.; McMahon-Pratt, D.; Walker, J.; Bernhagen, J.; Lolis, E. and Bucala, R. (2008) A Leishmania ortholog of macrophage migration inhibitory factor modulates host macrophage responses. J. Immunol. 180, 8250 - 8261 .

Kato Y.; Muto T.; Tomura T.; Tsumura H.; Watarai H.; Mikayama T.; Ishizaka K.; Kuroki R. (1996) The crystal structure of human glycosylation-inhibiting factor is a trimeric barrel with three 6-stranded beta-sheets. Proc Natl Acad Sci USA 93: 30073010.

Kayser, O; Kiderlen, A. F.; Laatsch, H.; Croft, S.L.; (2000) In vitro leishmanicidal activity of monomeric and dimeric naphthoquinones. Acta Tropica, v.77: $307-314$.

Kelly, S. M. and Price, N. C.; (1997) The application of circular dichroism to studies of protein folding and unfolding Biochimica et Biophysica Acta (BBA) V.1338(2):161185.

Kelly, S. M.; Jess, T. J.; Price, N. C.; (2005) How to study proteins by circular dichroism. Biochimica et Biophysica Acta 1751:119 - 139.

Kleemann, R., Mischke, R., Kapurniotu, A., Brunner, H., and Bernhagen, J. (1998) Specific reduction of insulin disulfides by macrophage migration inhibitory factor (MIF) with glutathione and dihydrolipoamide: potential role in cellular redox processes FEBS Lett. 430: 191 - 196.

Kleemann, R.; Kapurniotu, A.; Frank, R. W.; Gessner, A.; Mischke, R.; Flieger, O.; Juttner, S.; Brunner, H. and Bernhagen, J. (1998) Disulfide analysis reveals a role for macrophage migration inhibitory factor (MIF) as thiol-protein oxidoreductase J. Mol. Biol. v.280 85 - 102.

Kleemann, R.; Hausser, A.; Geiger, G.; Mischke, R.; Burger-Kentischer, A.; Flieger, O.; Johannes, F. J.; Roger, T.; Calandra, T.; Kapurniotu, A.; Grell, M.; Finkelmeier, D.; Brunner, H.; and Bernhagen, J. (2000) Intracellular action of the cytokine MIF to modulate AP-1 activity and the cell cycle through Jab1 Nature v.408: $211-216$.

Koebernick, H.; Grode, L.; David, J. R.; Rohde, W.; Rolph, M. S.; Mittrucker, H. W.; (2002) Macrophage migration inhibitory factor (MIF) plays a pivotal role in immunity against Salmonella typhimurium. Proc Natl Acad Sci USA v.99:13681-6.

Kudrin, A.; Scott, M.; Martin, S.; Chung, C.; Donn, R.; McMaster, A.;Ellison, S.; Ray, D.; Ray, K.; Binks, M. (2006) Human Macrophage Migration Inhibitory Factor A proven immunomodulatory cytokine? J. Bio Chem V.281 n.40, pp. 29641-29651

Laemmli U. K. (1970) Cleavage of structural proteins during the assembly of the head of bacteriophage T4. Nature 227: 680-5

Lainson, R.; Shaw, J. J. (1987) Evolution, classification and geographical distribution. In: Peters, W. \& Killick-Kendrick, R. The Leishmaniases in Biology and Medicine. Biology and Epidemiology, academic press Inc. London, v.1: 1 - 120.

Lakowicz J.R., (1983). "Principles of fluorescence spectroscopy". Plenum Press. 495pp.

Lubetsky, J. B.; Swope, M.; Dealwis, C.; Blake, P. and Lolis, E. (1999) Pro-1 of macrophage migration inhibitory factor functions as a catalytic base in the phenylpyruvate tautomerase activity. Biochemistry v. 38: $7346-7354$.

Lubetsky, J. B.; Dios, A.; Han, J.; Aljabari, B.; Ruzsicska, B.; Mitchell, R.; Lolis, E.; Al-Abed, Y. (2002) The Tautomerase activity of MIF is a potencial target for discovery of novel anti-inflammatory agents. J. Biol. Chem. v.277: 24976 - 24982.

Marfurt, J.; Nasereddin, A.; Niederwieser, I.; Jaffe, C. L.; Beck, H. P.; Felger, I.; (2003) Identification and differentiation of Leishmania species in clinical samples by PCR amplification of miniexon sequence and subsequent restriction fragment length polymorphism analysis. Journal of Clinical Microbiology, v.41(7): 3147 - 3153. 
Mischke, R.; Kleeman, R.; Brunner, H.; Bernhagen, J.; (1998) Cross-linking and mutational analysis of the oligomerization state of the cytokine macrophage migration inhibitory factor (MIF). FEBS Letters 427: 85 - 90.

Missiakas D., Betton, J. M., Minard, P., Yon, J. M.; (1990) Unfolding-refolding of the domains in yeast phosphoglycerate kinase: comparison with the isolated engineered domains Biochemistry 29(37): 8683-8689.

Miska, K. B.; Fetterer, R. H.; Lillehoj, H. S.; Jenkins, M. C.; Allen, P. C.; Harper, S. B. (2007) Characterization of macrophage migration inhibitory factor from Eimeria species infectious to chickens. Mol Biochem Parasitol 151: 173-83

Mühlhahn, P.; Bernhagen, J.; Czisch, M.; Georgescu, J.; Renner, C.; Ross, A.; Bucala, R.; Holak, T.; (1996) NMR characterization of structure, backbone dynamics, and glutathione binding of human macrophage migration inhibitory factor (MIF). Protein Sci v.5: $2095-2103$.

Munro, A.W.; Lindsay, J.G.; Coggins, J.R.; Kelly, S.M.; Price, N.C.; (1994) Structural and enzymological analysis of the interaction of isolated domains of cytochrome P450 BM3, FEBS Lett. 343: 70-74.

Nelson D. L. e Cox M.M.- Lehninger - Princípios de Bioquímica. 3a. Ed. 2003. Editora Sarvier.

Nelson R.M. e Long G.L., (1989). A general method of site-specific mutagenesis using a modification of the Thermus aquaticus polymerase chain reaction, Anal. Biochem. 180: $147-151$.

Nishibori, M.; Nakaya, N.; Tahara, A.; Kawabata, M.; Mori, S. and Saeki, K.; (1996) Presence of macrophage migration inhibitory factor (MIF) in ependyma, astrocytes and neurons in the bovine brain Neurosci. Lett. v.213: 193 - 196.

Nishihira, J.; Koyama, Y.; Mizue, Y.; (1998) Identification of macrophage migration inhibitory factor (MIF) in human vascular endothelial cells and its induction by lipopolysaccharide. Cytokine v.10:199-205.

Ouellete, M.; Drummelsmith, J.; Papadopoulou, B.; (2004) Leishmaniasis: drugs in the clinic, resistance and new developments. Drug Resistance Updates, v. 7(4 - 5):257 266.

Palmer, G. H.; Brayton, K. A.; (2007) Gene conversion is a convergent strategy for pathogen antigenic variation Trends Parasitol. v.23: 408 - 413.

Pastrana, D. V.; Raghavan, N.; FitzGerald, P.; Eisinger, S. W.; Metz, C.; Bucala, R.; Schleimer, R. P.; Bickel, C. and Scott, A. L. (1998) Infect. Immun. 66, 5955-5963.

Pearson, R. D \& Sousa, A. Q.; (1996) Clinical spectrum of leishmaniasis. Clinical Infectious Diseases, v.22: $1-13$.

Perez-Iratxeta C, MA A.-N. (2007) K2D2: estimate of protein secondary structure from circular dichroism spectra. BMC Structural Biology 8: 25

Peters C.; Aebischer, T.; Stierhof, Y. D.; Fuchs, M.; Overath, P. (1995) The role of macrophage receptors in adhesion and uptake of Leishmania mexicana amastigotes. $\mathrm{J}$ Cell Sci 108 Parte 12: 3715 - 3724.

Pimenta, P. F. P.; Saraiva, E. M. B.; Sacks, D. L.; The comparative fine structure and surface glyconjugate expression of three life stages of Leishmania major. Experimental Parasitology, v.72: 191 - 204, 1991.

Pimenta P. F.; Turco S. J.; McConville M. J.; Lawyer P. G.; Perkins P. V.; Sacks D. L. (1992) Stage-specific adhesion of Leishmania promastigotes to the andfly midgut. Science 256: 1812-1815.

Price, N. E.; Price, N. C.; Kelly, S.M.; McDonnell, J. M. (2005) The key role of protein flexibility in modulating IgE interactions, J. Biol. Chem. 280:2324- 2330. 
Ptitsyn, O. B.; (1995) Structures of folding intermediates Current Opinion in Structural Biology V.5 (1): 74-78

Pyle, M. E.; Korbonits, M.; Gueorguiev, M.; Jordan, S.; Kola, B.; Morris, D. G.; Meinhardt, A.; Powell, M. P.; Claret, F. X.; Zhang, Q.; Metz, C.; Bucala, R. and Grossman, A. B. (2003) Macrophage migration inhibitory factor expression is increased in pituitary adenoma cell nuclei J. Endocrinol. 176: 103 - 110.

Radstake, T. R. and Bucala, R. (2007) Macrophage migration inhibitory factor and its genetic association with arthritis: a work in progress Curr. Rheumatol. Rep. 9343 344.

Reyes J. L.; Terrazas, L. I.; Espinoza, B.; Cruz-Robles, D.; Soto, V.; Rivera-Montoya, I.; Gomez-Garcia, L.; Snider, H.; Satoskar, A. R.; Rodriguez-Sosa, M. (2006) Macrophage migration inhibitory factor contributes to host defense against acute Trypanosoma cruzi infection. Infect Immun. v.74(6):3170-3179.

Richardson, J. M.; Morrison, L. S.; Bland, N. D.; Bruce, S.; Coombs, G. H.; Mottram, J. C.; Walkinshaw, M. D. (2009) Structures of Leishmania major orthologues of macrophage migration inhibitory factor. Biochem Biophys Res Commun 380: 442-8.

Rodriguez-Sousa, M.; Rosas, L. E.; David, J. R.; Bojalil, R.; Satoskar, A. R.; Terrazas, L. I. (2003) Macrophage migration inhibitory factor plays a critical role in mediating protection against the helminth parasite Taenia crassiceps. Infect Immun. v.71: 1247 $-1254$.

Rosengren, E.; Bucala, R.; Aman, P.; Jacobsson, L.; Odh, G.; Metz, C. N. and Rorsman, H. (1996) The immunoregulatory mediator macrophage migration inhibitory factor (MIF) catalyzes a tautomerization reaction Mol. Med. v.2: 143 - 149.

Rosengren, E.; Aman, P.; Thelin, S.; Hansson, C.; Ahlfors, S.; Bjork, P.; Jacobsson, L. and Rorsman, H. (1997) The macrophage migration inhibitory factor MIF is a phenylpyruvate tautomerase FEBS Lett. v.417: 85 - 88 .

Royer, C. A. (2006). Probing protein folding and conformational transitions with fluorescence. Chem. Rev. 106(5):1769-1784.

Sacks D. L.; Brodin T. N. \& Turco S. J. (1990) Developmental modification of the lipophosphoglycan from Leishmania major promastigotes during metacyclogenesis. Mol Biochem Parasitol v.42: 225-233.

Sambrook J e Russell DW. (2001) Molecular Cloning: A Laboratory Manual. 3rd ed New York: Cold Spring Harbor Laboratory.

Santos, L. L.; and Morand, E. F. (2006) The role of macrophage migration inhibitory factor in the inflammatory immune response and rheumatoid arthritis. Wien. Med. Wochenschr. 156: $11-18$.

Sashinami, H.; Sakuraba, H.; Ishiguro, Y.; Munakata, A.; Nishihira, J.; Nakane, A. (2006) The role of macrophage migration inhibitory factor in lethal Listeria monocytogenes infection in mice. Microb Pathog. V.41(2-3): 111 - 118.

Satoskar, A. R.; Bozza, M.; Rodriguez, S. M.; Lin, G. David, J. R. (2001) Migrationinhibitory factor gene-deficient mice are susceptible to cutaneous Leishmania major infection. Infect Immun v.69: 906 - 911.

Scharton-Kersten, T. \& Scott, P.; (1995) The role of the innate immune response in Th1 cell development following Leishmania major infection. J Leukoc Biol. v.4: 515 522.

Shao, D.; Han, Z.; Lin, Y.; Zhang, L.; Zhong, X.; Feng, M.; Guo, Y.; Wang, H.; (2008) Detection of Plasmodium falciparum derived macrophage migration inhibitory factor homologue in the sera of malaria patients. Acta Trop 106:9-15.

Shaw, J. (1994) Taxonomy of the genus Leishmania: Present and Future Trends and their Implications. Memórias do Instituto Oswaldo Cruz, v.10: 471 - 478. 
Stamps, S. L.; Fitzgerald, M. C.; Whitman, C. P. (1998) Characterization of the role of the amino-terminal proline in the enzymatic activity catalyzed by macrophage migration inhibitory factor. Biochemistry 37: 10195-10202.

Sugimoto, H.; Suzuki, M.; Nakagawa, A.; Tanaka, I.; Nishihara, J. (1996) Crystal structure of macrophage migration inhibitory factor from human lymphocyte at $2.1 \AA$ resolution. FEBS Lett 389: 145 - 148.

Sun, H. W.; Bernhagen, J.; Bucala, R.; Lolis, E.; (1996) Crystal structure at $2.6 \AA$ resolution of human macrophage migration inhibitory factor. Proc Natl Acad Sci USA 93:5191-5196.

Suzuki, M. Sugimoto, H.; Nakagawa, A.; Tanaka, I.; Nishihara, J.; Sakai, M.; (1996) Crystal structure of the macrophage migration inhibitory factor from rat liver. Nat Struct Biol vol.3: $259-266$.

Suzuki, M.; Takamura, Y.; Maeno, M.; Tochinai, S.; Iyaguchi, D.; Tanaka, I.; Nishihira, J.; Ishibashi, T. (2004) Xenopus laevis macrophage migration inhibitory factor is essential for axis formation and neural development. J Biol Chem 279: 21406-21414.

Swope, M.; Sun, H.W.; Blake, P.R.; Lolis, E. (1998). Direct link between cytokine activity and a catalytic site for macrophage migration inhibitory factor. EMBO J. 17, 3534-3541.

Swope, M. D.\& Lolis, E. (1999) Macrophage migration inhibitory factor: cytokine, hormone, or enzyme? Rev Physiol Biochem Pharmacol v.139: 1 - 32.

Takahashi, A.; Iwabuchi, K.; Suzuki, M.; Ogasawara, K.; Nishihira, J. and Onoe, K. (1999) Antisense macrophage migration inhibitory factor (MIF) prevents anti-IgM mediated growth arrest and apoptosis of a murine B cell line by regulating cell cycle progression Microbiol. Immunol. v.43: $61-67$.

Tan, T. H.; Edgerton, S. A.; Kumari, R.; McAlister, M. S.; Roe, S. M.; Nagl, S.; Pearl, L. H.; Selkirk, M. E.; Bianco, A. E.; Totty, N. F.; Engwerda, C.; Gray, C. A.; Meyer, D. J. (2001) Macrophage migration inhibitory factor of the parasitic nematode Trichinella spiralis. Biochem J. 15:357(Pt 2):373-383. Erratum in: Biochem J 358 $(\mathrm{Pt}): 791$. Rowe SM [corrected to Roe SM].

Taylor, A. B.; Johnson, W. H.; Jr, Czerwinski, R. M.; Li, H. S.; Hackert, M. L. \& Whitman, C. P. (1999) Biochemistry 38, 7444-7454.

Theodos, C.M.\& Titus R.G. (1993) Salivary gland material from the sand fly Lutzomyia longipalpis has an inhibitory affect on macrophage function in vitro. Parasite Immunology, v.151: 4891 - 4901.

Tiuman, T. S.; Ueda-Nakamura, T.; Cortez, D. A. G.; Filho, B. P. D.; Morgado-Diaz, J. A.; De Souza, W.; Nakamura, C. V.; (2005) Antileishmanial Activity of Parthenolide, a Sesquiterpene Lactone Isolated from Tanacetum parthenium. Antimicrobial Agents and Chemotherapy, v.49(1):176 - 182.

Turco, S. J. \& Descoteaux, A.; (1992). The lipophosphoglycan of Leishmania parasites. Annu Rev. Microbiol. 46: 65-94.

Xu, X., Wang, B., Ye, C., Yao, C., Lin, Y., Huang, X., Zhang, Y., and Wang, S. (2008) Overexpression of macrophage migration inhibitory factor induces angiogenesis in human breast cancer Cancer Lett. 261147157

Yabunaka, N., Nishihira, J., Mizue, Y., Tsuji, M., Kumagai, M., Ohtsuka, Y., Imamura, M., and Asaka, M. (2000). Elevated serum content of macrophage migration inhibitory factor in patients with type 2 diabetes Diabetes Care 23256258.

Weiser, W. Y.; Temple, P. A.; Witek-Giannotti, J. S.; Remold, H. G.; Clark, S. C.; David, J. R. (1989) Molecular cloning os cDNA encoding a human macrophage migration inhibitory factor. Pro. \& Natl. Acad. Sci. USA 86: 7522 - 7526. 
Weiser, W. Y.; Pozzi, L. M. \& David, J. R. J. (1991) Human recombinant migration inhibitory factor activates human macrophages to kill Leishmania donovani. Immun. 147: 2006-2011.

Who (2010) http://www.who.int/leishmaniasis/ Acessado em 30/12/2010.

Wortmann, G.; Sweeney, C.; Houng, H. S.; Aronson, N.; Stiteler, J.; Jackson, J. and Ockenhouse, C.; (2001) Rapid diagnosis of leishmaniasis by fluorogenic polymerase chain reaction Am. J. Trop. Med. Hyg., 65(5): 583-587.

Zang X, Taylor P, Wang JM, Meyer DJ, Scott AL, Walkinshaw MD, Maizels RM. (2002) Homologues of human macrophage migration inhibitory factor from a parasitic nematode. Gene cloning, protein activity, and crystal structure. J Biol Chem. 277(46):44261-7.

Zeng FY, Weiser WY, Kratzin H, Stahl B, Karas M, Gabius HI. (1993) The major binding-protein of the interferon antagonist sarcolectin in human placenta is a macrophage-migration inhibitory factor. Archiv Bioch Biophvs 303: 74-80.

Zerovnik, E.; Janjicâ, V.; Francky, A. and Mozeticï-Francky, B. (1999) Equilibrium and transient intermediates in folding of human macrophage migration inhibitory factor. Eur. J. Biochem. v. 260: 609-618. 